Universidade de São Paulo

Instituto de Física

\title{
Estudo da Distrofia Muscular em Camundongos $m d x$ com Ressonância Magnética Nuclear
}

\author{
Aurea Beatriz Martins Bach
}

Orientador: Prof. Dr. Said Rahnamaye Rabbani

Dissertação de mestrado apresentada ao Instituto de Física para a obtenção do título de Mestre em Ciências.

Banca examinadora:

Prof. Dr. Said Rahnamaye Rabbani (IF-USP)

Prof. Dr. Antonio Martins Figueiredo Neto (IF-USP)

Prof. Dr. Tito José Bonagamba (IFSC-USP)

São Paulo

2010 


\title{
FICHA CATALOGRÁFICA
}

Preparada pelo Serviço de Biblioteca e Informação do Instituto de Física da Universidade de São Paulo

\author{
Bach, Aurea Beatriz Martins
}

"Estudo da distrofia muscular em camundongos mdx com ressonância magnética nuclear" - São Paulo, 2010.

Dissertação (Mestrado) - Universidade de São Paulo. Instituto de Física, Depto. de Geral

Orientador: Prof. Dr. Rabbani, Said Rahnamaye

Área de Concentração: Ressonância Magnética Nuclear

Unitermos: 1. Ressonância magnética nuclear; 2. Física médica; 3. Biofísica; 4. Radiologia. 
Dedico este trabalho à memória de minha querida irmã Leila, que se foi deixando muitas saudades e boas lembranças. 



\section{Agradecimentos}

Agradeço ao Eduardo, pela contribuição pessoal, afetiva e intelectual imensurável.

Ao Prof. Said Rahnamaye Rabbani pela orientação e por confiar em meu trabalho e em minha capacidade.

À Profa. Mariz Vainzof agradeço pelo auxílio, pela confiança e pela liberdade concedida a mim para a realização deste trabalho.

Ao Prof. Ronaldo Pitombo agradeço pela colaboração na disponibilização do liofilizador para a preparação de minhas amostras. Ao Gledson Manso Guimarães, agradeço pela contribuição no processo de liofilização.

À Claudia Madalena Cabrera Mori, agradeço pela grande ajuda na manutenção dos camundongos e por ser sempre tão solícita e paciente.

Ao Prof. Nestor Felipe Caticha Alfonso agradeço pelas discussões e sugestões tão oportunas.

Ao Prof. Paulo Eduardo Artaxo Neto agradeço pelo esclarecimento de dúvidas e por todo auxílio concedido de modo tão atencioso.

Ao Antonio Bloise agradeço pelo conhecimento a mim transferido, pela orientação na aquisição dos espectros, pela colaboração na realização das medidas e pela participação na minha formação.

Ao Joel agradeço pela ajuda na compreensão de aspectos teóricos e práticos envolvidos neste trabalho e por todo o auxílio a mim oferecido.

Ao Alexandre, agradeço pela ajuda na realização das medidas de ressonância. À Silvana agradeço por sempre ser solícita e por todo o apoio.

À Paula, Daniele, Vanessa, Dinorah e amigos do Centro de Estudos do Genoma Humano, agradeço pela ajuda no laboratório, pelas conversas, pelas risadas, pela amizade e pelo respeito.

Ao casal Poliana e Bira, agradeço pelo incentivo, pela amizade e por toda a ajuda que sempre me deram.

Aos meus pais, pelo carinho e por acreditarem em minha capacidade.

Ao Vitor, à Laura e à Sonia, por crescerem comigo e fazerem parte do que sou hoje.

À CAPES, ao CNPq e à FAPESP agradeço pelo apoio financeiro. 


\section{Sumário}

1 Introdução $\quad 15$

2 Ressonância Magnética Nuclear $\quad 18$

2.1 Aspectos históricos . . . . . . . . . . . . 18

2.2 Descrição Quântica . . . . . . . . . . . 20

2.2.1 Spin e Momento Magnético Nuclear . . . . 20

2.2.2 Spin nuclear em um campo magnético estático 22

2.2.3 Transições entre níveis de energia . . . . 23

2.2.4 Magnetização Resultante ......... 25

2.3 Tratamento clássico . . . . . . . . . . . 28

2.3.1 Descrição clássica . . . . . . . . . . 28

2.3.2 Equações de Bloch ........... 31

2.3.3 O referencial girante .......................... 33

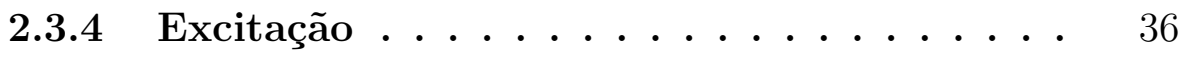

2.4 Relaxação . . . . . . . . . . . . . 37

2.5 Transformada de Fourier . . . . . . . . . . . 42

2.6 Espectroscopia de Ressonância Magnética Nuclear . 44

2.6.1 Deslocamento Químico ........... 44

2.6.2 Acoplamento spin-spin ou acoplamento J . . 48

$2.7 \mathrm{O}$ espectrômetro ..................... 50

3 A Distrofia Muscular Duchenne 53

3.1 Distrofias Musculares ............ 53

3.2 Distrofia Muscular Duchenne .......... 54

3.3 O Complexo Distrofina-Glicoproteínas . . . . . . 56

3.4 O camundongo $\boldsymbol{m \boldsymbol { d }} \boldsymbol{x}$, modelo animal para a DMD . 58

3.5 A espectroscopia por RMN no estudo das distrofias musculares com ausência de distrofina . . . . . 60 
4 Procedimentos Experimentais 64

4.1 Animais . . . . . . . . . . . . . . . . 64

4.2 Preparação das Amostras . . . . . . . . . . . . . . . . 64

4.3 Metodologias de Espectroscopia por RMN . . . . . 65

4.3.1 Medidas de tempo de relaxação longitudinal T1 (spin-rede) . . . . . . . . . . . 65

4.3.2 Espectroscopia de alta resolução de ${ }^{1} H \quad \ldots \quad 67$

4.3.3 Espectroscopia bidimensional de correlação homonuclear ............... 69

4.4 Processamento dos dados e análise estatística . . . . 72

4.5 Análise Histológica . . . . . . . . . . . . . . . 74

5 Resultados $\quad 76$

5.0.1 Comparação direta das integrais dos picos observados ............... 80

5.0.2 Análise das Componentes Principais (PCA) 86

5.0.3 Resultados Gerais . . . . . . . . . . . . 100

5.0.4 Análise Histológica . . . . . . . . . . . . . 103

$\begin{array}{lll}6 & \text { Discussão } & 105\end{array}$

7 Conclusões e Perspectivas 112

A Principal Component Analysis 114 


\section{Lista de Figuras}

2.1 Espectro de álcool etílico obtido em 1951. . . . . . 19

2.2 Quantização da componente $z$ do momento angular de spin para o próton $(I=1 / 2) \ldots \ldots \ldots 22$

2.3 Níveis de energia de um núcleo com spin igual a $1 / 2$ e de um núcleo com spin igual a 1. . . . . . . . 24

2.4 Vetor Magnetização Resultante. . . . . . . . . 27

2.5 Momentos magnéticos da amostra e Magnetização resultante....................... 31

2.6 Campo efetivo sobre a amostra no referencial girante. 35

2.7 Magnetização resultante $\vec{M}$ sob efeito do campo magnético $\overrightarrow{B_{e f}}=\overrightarrow{B_{1}} \ldots \ldots \ldots \ldots$

2.8 Ação de pulsos de radiofrequência sobre a magnetização $\vec{M}$. . . . . . . . . . . . . . . . 37

2.9 Relaxação longitudinal ou spin-rede. . . . . . . . 40

2.10 Relaxação transversal ou relaxação spin-spin. . . . . 41

2.11 Decaimento exponencial das componentes $x$ e $y$ da magnetização transversal [24]. . . . . . . . . . 43

2.12 Referências de chemical shift. . . . . . . . . 47

2.13 Níveis de energia para dois sistemas de spins com núcleos de spin igual a $1 / 2$. . . . . . . . . 49

2.14 Espectro de RMN simulado referente ao próton 5 da

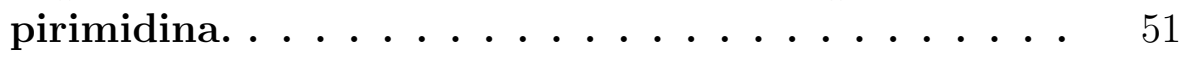

3.1 Aspecto histopatológico do músculo distrófico de paciente com DMD comparado com músculo normal.

3.2 Representação gráfica do Complexo Distrofina-Glicoproteínas. 57

4.1 Sequência de pulsos utilizada no experimento de inversãorecuperação para determinação do T1. . . . . . . 67

4.2 Intensidades dos picos de creatina, taurina e lactato em função do tempo de recuperação $\tau$. . . . . . . . 67 
4.3 Representação esquemática da sequência de $\pi / 4$ usada nas amostras de quadríceps. . . . . . . . . 68

4.4 Representação esquemática da sequência de $\pi / 2$ usada nas amostras de diafragma. . . . . . . . . 69

4.5 Representação esquemática da seqüência COSY-90. 71

4.6 Representação esquemática da seqüência COSY-45. 71

4.7 Representação esquemática da sequência de pulsos utilizada para a determinação da duração do pulso de $\pi / 2 . \ldots \ldots \ldots \ldots \ldots \ldots$

4.8 Intensidade do pico de TSP para cada valor de duração de pulso $(\mathrm{pw})$ utilizado. . . . . . . . . .

5.1 Espectros de ${ }^{1} \mathrm{H}$ RMN de amostras de quadríceps de camundongos $\boldsymbol{m d x}$ e de controle com idades diferentes para deslocamentos químicos menores que o da

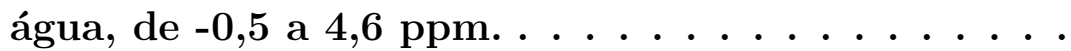

5.2 Espectros de ${ }^{1} \mathrm{H}$ RMN de amostras de diafragma de camundongos $\boldsymbol{m} \boldsymbol{d} \boldsymbol{x}$ e de controle com idades diferentes. 78

5.3 Espectros de ${ }^{1} \mathrm{H}$ RMN de amostras de quadríceps de camundongos $m d x$ e de controle com idades diferentes para deslocamentos químicos maiores que o da água, de 5,1 a 9,2 ppm. . . . . . . . . . .

5.4 Espectro de ${ }^{1} \mathrm{H}$ RMN mostrando alguns dos picos

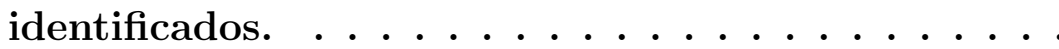

5.5 Espectro bi-dimensional de amostra de quadríceps de camundongo $m d x$ (COSY-90). . . . . . . .

5.6 Médias \pm desvio padrão dos valores das integrais dos picos observados nas amostras de quadríceps e diafragma de camundongos $m d x$ e de controle. . . .

5.7 Médias \pm desvio padrão dos valores das integrais dos picos observados nas amostras de quadríceps e diafragma de camundongos $m d x$ de controle com 3 meses de idade. ................. 84

5.8 Médias \pm desvio padrão dos valores das integrais dos picos observados nas amostras de quadríceps e diafragma de camundongos $m d x$ e de controle com 6 meses de idade. . . . . . . . . . . . .

5.9 Médias \pm desvio padrão dos valores de integral dos picos observados nas amostras de quadríceps e diafragma de camundongos de controle com 3 e 6 meses de idade. . . . . . . . . . . . . . . 
5.10 Médias \pm desvio padrão dos valores de integral dos picos observados nas amostras de quadríceps e diafragma de camundongos $m d x$ com 3 e 6 meses de

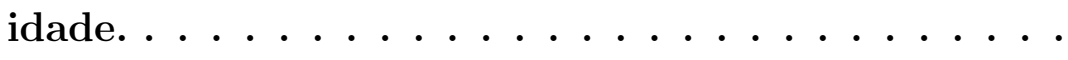

5.11 Gráfico de score para a comparação entre as amostras de quadríceps de camundongos $\boldsymbol{m d x}$ e de controle. 88

5.12 Gráfico de loading para as amostras de quadríceps

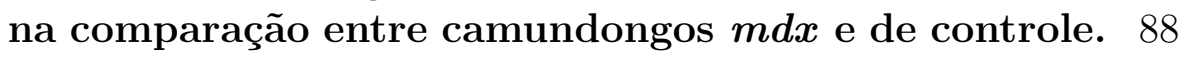

5.13 Gráfico de score na comparação entre camundongos $m d x$ e de controle para as amostras de diafragma. .

5.14 Gráfico de loading para as amostras de diafragma na comparação entre camundongos $\boldsymbol{m d x}$ e de controle. 90

5.15 Gráfico de score para as amostras de quadríceps na comparação entre camundongos $m d x$ com 3 meses e camundongos de controle de mesma idade. . . . . .

5.16 Gráfico de loading na comparação entre camundongos $m d x$ com 3 meses e camundongos de controle com a mesma idade para as amostras de quadríceps.

5.17 Gráfico de score para as amostras de diafragma na comparação entre camundongos $m d x$ e de controle com 3 meses de idade. . . . . . . . . . . . .

5.18 Gráfico de loading para as amostras de diafragma na comparação entre camundongos $m d x$ com 3 meses e camundongos de controle com a mesma idade. . . .

5.19 Gráfico de score para as amostras de quadríceps na comparação entre camundongos $m d x$ e de controle com 6 meses de idade. . . . . . . . . . . . .

5.20 Gráfico de loading para as amostras de quadríceps na comparação entre camundongos $m d x \operatorname{com} 6$ meses e camundongos de controle com a mesma idade.

5.21 Gráfico de score para as amostras de diafragma na comparação entre camundongos $m d x$ e de controle com 6 meses de idade. . . . . . . . . . . .

5.22 Gráfico de loading para a comparação entre amostras de diafragma de camundongos $m d x$ com 3 meses e camundongos de controle com a mesma idade. . .

5.23 Gráfico de score para as amostras de quadríceps na comparação entre camundongos de controle com 3 e 6 meses. . . . . . . . . . . . . . . 
5.24 Gráfico de loading para as amostras de quadríceps na comparação entre camundongos de controle com 3 e 6 meses de idade. . . . . . . . . . . . .

5.25 Gráfico de score para as amostras de diafragma na comparação entre camundongos de controle com 3 e 6 meses de idade. . . . . . . . . . . . .

5.26 Gráfico de score para as componentes amostras de quadríceps na comparação entre camundongos $\boldsymbol{m d x}$ com 3 e 6 meses de idade.

5.27 Gráfico de loading para as amostras de quadríceps na comparação entre camundongos $m d x \operatorname{com} 3$ e 6 meses de idade. . . . . . . . . . . . .

5.28 Gráfico de score para as amostras de diafragma na comparação entre camundongos $m d x$ com 3 e 6 meses de idade. . . . . . . . . . . . . 100

5.29 Aspecto histopatológico dos músculos quadríceps e diafragma de camundongos sadios e distróficos. . . . 104 


\section{Lista de Tabelas}

2.1 Sensibilidade relativa dos núcleos mais frequentemente utilizados em experimentos de RMN. . . . 28

4.1 Valores de T1 observados. . . . . . . . . 68

5.1 Região de integração dos picos selecionados nos espectros de ${ }^{1}$ H-RMN e metabólitos associados. . . . 81

5.2 Metabólitos alterados na comparação entre camundongos $m d x$ e camundongos de controle com 3 ou 6 meses de idade. . . . . . . . . . . . . . 101

5.3 Metabólitos alterados na comparação entre camundongos $m d x$ com diferentes idades e camundongos de controle com diferentes idades. . . . . . . . . 102 


\section{Resumo}

Atualmente, a espectroscopia de Ressonância Magnética Nuclear (RMN) in vitro tem sido extensivamente empregada para estudar tecidos biológicos, atuando como uma poderosa ferramenta de análise química. Em particular, a RMN de próton $\left({ }^{1} \mathrm{H}\right)$ e de fósforo $\left({ }^{31} \mathrm{P}\right)$ vem sendo utilizada para estudar o metabolismo muscular de animais portadores de deficiências genéticas, como os camundongos com distrofia muscular $m d x$, modelos para a distrofia muscular Duchenne (DMD). A DMD, que afeta humanos, é um distúrbio recessivo ligado ao cromossomo- $\mathrm{X}$ e ocorre em 1 para cada 3500 nascidos vivos do sexo masculino. A DMD é caracterizada pela ausência da proteína distrofina, o que provoca um processo progressivo e rápido de degeneração muscular. Atualmente, o acompanhamento da evolução da doença e de benefícios de tratamentos é feito através de biópsias do tecido muscular. Neste estudo foram realizadas medidas de RMN de ${ }^{1} \mathrm{H}$ em amostras de diafragma e do músculo quadríceps femural de camundongos $m d x$ e de controle com 3 e 6 meses de idade. Os resultados foram comparados com a análise histológica dos mesmos tecidos. O objetivo deste trabalho é monitorar o desenvolvimento normal dos músculos de animais de controle e o progresso da distrofia nos músculos de animais $m d x$, através da análise dos espectros de RMN. Foi possível identificar diferenças entre os grupos de animais a partir das integrais dos picos observados, mostrando que a distrofia acarreta alterações em diversas vias metabólicas nos camundongos $m d x$. Estes resultados formam a base para estudos da doença in vivo, para que então seja possível diferenciar músculos distróficos de músculos sadios e caracterizar diferentes estágios de evolução da doença de maneira não invasiva. 


\section{Abstract}

Currently, Nuclear Magnetic Resonance spectroscopy in vitro has been extensively used to study biological tissues, acting as a powerful tool for chemical analysis. In particular, NMR of proton $\left({ }^{1} \mathbf{H}\right)$ and phosphorus $\left({ }^{31} \mathrm{P}\right)$ has been used to study muscle metabolism in animals with genetic diseases, such as mice with muscular dystrophy $m d x$, models for Duchenne muscular dystrophy (DMD). The DMD, which affects humans, is a recessive disorder linked to $\mathrm{X}$-chromosome and occurs in 1 each 3,500 live births male. The DMD is characterized by the absence of dystrophin protein, which causes a progressive and rapid degeneration. Currently, the monitoring of disease progression and benefits of treatments is made by biopsy of muscle tissue. In this study, ${ }^{1} \mathrm{H}$ NMR spectrum were acquired from samples of diaphragm and quadriceps muscle of $\boldsymbol{m d x}$ and control mice 3 or 6 months-old. Results were compared with histological analysis of the same tissues. The objective of this study is to monitor the normal development of the muscles of control animals and the progress of dystrophy in the muscles of $m d x$ animals by analyzing the NMR spectra. Differences were found between the groups of animals comparing the integrals of the observed peaks, showing that dystrophy leads to alterations in several methabolic pathways in the $m d x$ mouse. These results form the basis for studies of the disease in vivo, so then it can be possible to distinguish dystrophic muscles from healthy muscles and characterize different stages of the disease noninvasively. 


\section{Capítulo 1}

\section{Introdução}

As distrofias musculares são um grupo heterogêneo de doenças genéticas em que se observa degeneração muscular progressiva. A distrofia muscular mais comum é a distrofia muscular Duchenne (DMD), em que os pacientes apresentam fenótipo severo, e raramente sobrevivem após a terceira década de vida. Não há cura para as distrofias musculares, e até o momento os pacientes só têm à disposição tratamentos que tentam desacelerar o avanço da doença. Diferentes linhas de pesquisa buscam a melhor compreensão dos fenômenos biológicos envolvidos nas distrofias musculares, além de haver diversas outras linhas de pesquisa buscando novas possibilidades terapêuticas. Em todos os casos, as avaliações de benefícios de terapias ou a caracterização do estágio da doença dependem da análise histológica de tecido muscular, o que envolve a coleta de biópsias em pacientes e a eutanásia dos modelos animais. $\mathrm{O}$ uso de técnicas de Ressonância Magnética Nuclear (RMN) na avaliação do estágio de evolução das distrofias possibilitaria a realização de estudos in vivo em animais, e a avaliação dos pacientes de maneira não invasiva. Há na literatura diversos trabalhos envolvendo o uso da RMN no estudo de distrofias musculares, desde aqueles envolvendo métodos de imageamento $[1,2,3,4,5,6,7,8]$, passando por estudos envolvendo espectroscopia de próton $[9,10,11,12,13,14]$, fósforo [5, 15, 16, 17, 18, 19, 20] e carbono [21], estudos envolvendo análise lipídica de soro por espectroscopia de próton [22] e até estudo avaliando efeitos de terapia gênica de maneira não invasiva através da RMN [23]. Entretanto, até o momento não há uma padronização metodológica para aplicação da RMN no estudo das distrofias musculares, em pacientes ou em modelos animais.

A espectroscopia de RMN é uma das mais importantes técni- 
cas espectroscópicas da atualidade, com aplicações que vão desde a medicina e a química até aplicações industriais e computação quântica. A espectroscopia por RMN fornece informações estruturais e dinâmicas, de maneira não invasiva e não destrutiva. A RMN possibilita a determinação da estrutura tridimensional de moléculas em estado líquido, a análise qualitativa e quantitativa de componentes de diferentes materiais e substâncias, e em especial a análise de metabólitos em tecidos e órgãos de seres vivos, permitindo inclusive que esta análise seja realizada in vivo, de maneira não invasiva. Há ainda o uso da RMN para realização de imagens, hoje fundamental para a medicina, especialmente por se tratar de uma técnica segura por não envolver uso de radiação ionizante. Em particular, a espectroscopia por RMN tem possibilitado estudos denominados de metaboloma, em que o metabolismo de seres vivos em diferentes condições é mapeado, através da identificação e da quantificação de metabólitos.

Considerando-se as biópsias necessárias para a avaliação do estágio da doença e de benefícios de tratamentos em pacientes com DMD, e a dificuldade de se acompanhar de maneira não invasiva e continuada possíveis terapias nos modelos animais para a DMD, os objetivos deste trabalho são:

- O desenvolvimento de uma metodologia de avaliação do estágio da doença em camundongos $m d x$, modelos murinos para a DMD, com o uso de espectroscopia de RMN de próton, e

- A caracterização de metabólitos chave na classificação do estágio da doença nos animais, para posteriormente se buscar a validação da metodologia in vivo.

Em linhas gerais este trabalho está dividido da seguinte maneira:

- Capítulo 2: Explanação teórica a respeito das bases físicas envolvidas no fenômeno de RMN. São feitas paralelamente uma descrição quântica e uma descrição clássica do fenômeno de RMN, seguidos por descrição dos mecanismos de relaxação observados em experimentos de RMN. Apresenta uma descrição dos fenômenos característicos da espectroscopia por RMN, com detalhamento nos fenômenos de desvio químico e acoplamento escalar, fundamentais para a compreensão de um espectro de RMN. Por fim, é feita uma breve descrição do espectrômetro de RMN. 
- Capítulo 3: Apresentação de uma descrição da DMD e das bases moleculares da doença, seguida por descrição do modelo murino para a DMD, o camundongo $m d x$, e por um levantamento bibliográfico do uso da RMN do estudo da DMD.

- Capítulo 4: Descrição dos materiais e métodos utilizados no trabalho. Inicialmente é feita a descrição da metodologia de preparação das amostras para RMN, seguida pela descrição das sequências de pulso utilizadas e da padronização dos parâmetros das mesmas. São descritos os métodos de análise estatísticas utilizados, com uma breve explanação sobre o método PCA (Principal Component Analysis), e por fim é feita a descrição da metodologia envolvida na análise histológica.

- Capítulo 5: Descrição dos resultados obtidos.

- Capítulo 6: Discussão dos resultados.

- Capítulo 7: Conclusões a respeito dos resultados obtidos e perspectivas para trabalhos posteriores.

- Apêndice A - Principal Component Analysis: Descrição do método de análise por componentes principais (PCA). 


\section{Capítulo 2}

\section{Ressonância Magnética Nuclear}

\subsection{Aspectos históricos}

O conceito de spin foi sugerido no início dos anos 20 , com previsão teórica feita por Uhlenbeck e Goldsmith verificação experimental feita por Stern e Gerlach, que verificaram que um feixe atômico submetido a um campo magnético não homogêneo é desviado de acordo com a orientação dos momentos magnéticos dos elétrons. Em 1924, Pauli sugeriu a existência de núcleos atômicos com momento angular, o que explicaria a estrutura hiperfina observada em espectros atômicos. Nos anos 30, após aperfeiçoamento das experiências de Stern e Gerlach, foi possível determinar o momento magnético dos núcleos atômicos.

Em 1939, Rabi e colaboradores submeteram um feixe de moléculas de hidrogênio a um campo magnético não homogêneo, e em seguida a um campo magnético homogêneo juntamente com radiação de frequência variável na faixa de radio-frequência. Foi observado que em um determinado valor de frequência o feixe molecular absorvia energia e sofria um desvio. Este experimento marca a primeira observação do fenômeno de ressonância magnética nuclear.

Em 1945, foi observado pela primeira vez o fenômeno de RMN em amostras líquidas e sólidas, por dois grupos diferentes, de maneira independente. Bloch, Hansen e Packard, na Universidade de Stanford, e Purcell, Torrey e Pound, na Universidade de Harvard, ao realizarem medidas para determinação de momento magnético nuclear, observaram sinais de absorção de radio-frequência por água e parafina, respectivamente. Estes resultados fizeram com que Bloch e Purcell recebessem o Prêmio Nobel de Física em 1952. 
Em 1949, Proctor e Yu e, independentemente, Dickinson observaram que a frequência de ressonância dos núcleos variava com modificações no seu ambiente químico. Ou seja, núcleos na mesma molécula absorviam em diferentes frequências de ressonância. Em 1951, Arnold, juntamente com Bloch, Packard e outros colaboradores, utilizaram etanol $\left(\mathrm{CH}_{3}-\mathrm{CH}_{2}-\mathrm{OH}\right)$ num experimento de RMN quando se costumava utilizar água. Foram observadas três linhas espectrais do núcleo de hidrogênio com áreas na proporção de $3: 2: 1$, associadas respectivamente aos núcleos de hidrogênio nos três sítios químicos da molécula de etanol: três no grupo $\mathrm{CH}_{3}$, dois no grupo $\mathrm{CH}_{2}$ e um no grupo $\mathrm{OH}$. Este fenômeno foi chamado de deslocamento químico (chemical shift) (Figura 2.1). Tais descobertas permitiram ampliar a utilização do fenômeno de RMN para o campo da espectroscopia, e assim se originou a Espectroscopia por Ressonância Magnética Nuclear de alta resolução. Hoje em dia, a ERMN é uma ferramenta importante em diferentes áreas como a Física, a Química e a Medicina.

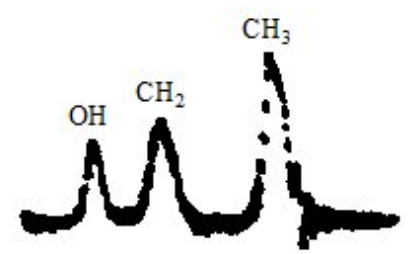

Figura 2.1: Espectro de álcool etílico obtido em 1951.

Em 1953 foi colocado no mercado o primeiro espectrômetro de RMN comercial. Em 1970, foi desenvolvida a espectroscopia pulsada, com a aplicação de pulsos de radiofrequência e de transformada de Fourier para a obtenção de espectros. Até o momento havia apenas espectrômetros de variação contínua da radio-frequência ou do campo magnético aplicado à amostra, e o desenvolvimento da espectroscopia por RMN pulsada permitiu que houvesse um salto de qualidade na área. Assim, tornou-se possível por exemplo a realização de medidas em amostras muito mais diluídas e o uso de diferentes núcleos como sondas magnéticas em RMN.

A importância da RMN tem crescido consideravelmente, em diversas áreas do conhecimento. Hoje, a RMN tem papel fundamental em áreas como Química, Física, Medicina e Biociências. 
Diversos Prêmios Nobel foram concedidos a estudiosos nesta área, como o físico-químico suíço Richard R. Ernst, que recebeu o Prêmio Nobel em Química em 1991 por suas contribuições ao desenvolvimento de técnicas experimentais para RMN, e o químico Paul C. Lauterbur juntamente com o físico Peter Mansfield, que receberam o Prêmio Nobel de Medicina em 2003 pelo desenvolvimento de técnicas de imageamento por RMN.

\subsection{Descrição Quântica}

\subsubsection{Spin e Momento Magnético Nuclear}

As propriedades magnéticas do núcleo atômico são a base para a RMN. Os núcleos atômicos são constituídos de prótons e nêutrons, partículas que possuem momento angular e momento magnético. Os núcleos podem ter spin nuclear inteiro, semi-inteiro ou nulo. Se o núcleo em questão possuir número ímpar de prótons e número par de nêutrons, ou número par de prótons e ímpar de nêutrons (número ímpar de nucleons) o valor de seu spin nuclear será semiinteiro. Alguns núcleos com spin nuclear semi-inteiro comumente utilizados em experimentos de NMR são ${ }^{1} H,{ }^{13} C,{ }^{31} P$ e ${ }^{23} N a$. Se o núcleo possuir número par de prótons e de nêutrons, o spin nuclear será igual a zero, assim como o seu momento magnético. Estes núcleos não exibem sinal em experimentos de RMN. Alguns exemplos de núcleos que não possuem momento magnético e portanto não podem ser avaliados em experimentos de RMN, pois não exibem sinal, são: ${ }^{14} C,{ }^{32} \mathrm{P}$ e ${ }^{36} \mathrm{Cl}$. Núcleos que possuem número ímpar de prótons e de nêutrons possuem spin nuclear inteiro. Estes núcleos apresentam sinal em experimentos de RMN, porém não são comumente utilizados pois apresentam linhas espectais largas. Este alargamento das linhas ocorre em núcleos com spin diferente de 1/2. Nesta situação, o núcleo possui momento de quadrupolo elétrico além do momento de dipolo magnético, pois não há distribuição esférica das cargas elétricas em torno do núcleo. Este momento de quadrupolo elétrico interage com o ambiente eletrônico do átomo, diminuindo o tempo de vida dos estados magnéticos nucleares. De acordo com o Princípio da Incerteza, esta diminuição no tempo de duração dos estados de spin magnético leva a uma maior incerteza na energia destes estados, o que por fim leva a um alargamento das bandas no espectro de RMN. Assim, núcleos com spin igual a 1/2 
apresentam bandas mais estreitas, o que faz com que sejam mais frequentemente utilizados como sondas em RMN. Certos núcleos, com spin nuclear diferente de $1 / 2$ mas com pequeno momento de quadrupolo elétrico também podem ser utilizados em experimentos de RMN, como o deutério $\left({ }^{2} H\right)$.

A maioria dos núcleos atômicos possuem ao menos um isótopo com momento angular de spin, $\vec{I}$, e momento magnético, $\vec{\mu}$, diferentes de zero. $\mathrm{O}$ momento angular de spin do núcleo pode ser representado pelo operador momento angular, $\hat{I}$, que quando atua sobre uma autofunção (uma função de onda do spin nuclear) $\psi_{N}$ gera autovalores $I$ de acordo com a equação:

$$
\hat{I} \psi_{N}=[I(I+1)]^{\frac{1}{2}} \psi_{N}
$$

onde $I$ é o número quântico de spin nuclear.

O momento magnético do núcleo é proporcional à magnitude do seu spin, $I$, e ambos são relacionados pela expressão

$$
\vec{\mu}=\gamma_{N} \hbar \vec{I}
$$

onde $\gamma_{N}$ é uma característica nuclear fundamental conhecida por razão giromagnética.

A componente na direção $z$ de $\vec{I}$ também é quantizada, e quando o operador $\bar{I}_{z}$ atua sobre $\psi_{N}$ temos a seguinte relação:

$$
\bar{I}_{z} \psi_{N}=m_{I} \psi_{N}
$$

Assim, a componente $I_{z}$ do momento angular de spin nuclear pode assumir $2 I+1$ valores:

$$
I_{z}=\hbar m_{I} \quad m_{I}=I, I-1, \cdots, 0, \cdots,-I+1,-I
$$

sendo $m_{I}$ o número quântico magnético do núcleo, que caracteriza o autoestado do núcleo em questão, e $\hbar$ correspondendo à constante de Planck, $h$, dividida por $2 \pi$.

Os prótons, isoladamente, possuem momento angular de spin $I=1 / 2$, e a componente na direção $z$ do momento angular, também chamada de spin nuclear, é dada pela relação a seguir.

$$
I_{z}= \pm \hbar I
$$

Assim, o próton pode assumir apenas dois estados, caracterizados pelo número quântico magnético, $m_{I}= \pm 1 / 2$ (Figura 2.2). 


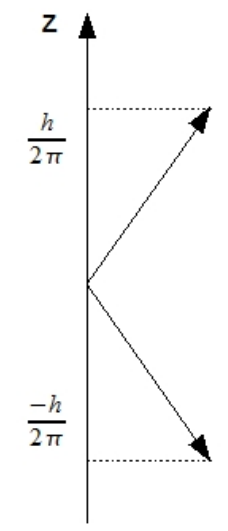

Figura 2.2: Quantização da componente $z$ do momento angular de spin para o próton $(I=1 / 2)$.

Temos também que a magnitude do momento magnético na direção $z$ pode assumir apenas dois valores (2.6).

$$
\mu_{z}=\gamma \hbar m_{i}= \pm \gamma \hbar I=\frac{ \pm \gamma \hbar}{2} .
$$

De acordo com 2.6, o próton pode ser tratado como um dipolo magnético, sendo que a componente $z$ do momento magnético, $\mu_{z}$, pode assumir orientação paralela ou antiparalela com relação à direção do eixo $z$ do sistema de coordenadas. Ou seja, tanto o valor do momento magnético $\mu$ como o valor de sua projeção sobre o eixo $z$ são quantizados. A equação 2.6 pode também ser escrita da seguinte maneira:

$$
\mu_{z}=g_{N} \mu_{N} m_{I}
$$

onde $g_{N}$ é o fator nuclear, caracterizado pela razão da carga nuclear pela sua massa, e $\mu_{N}$ é o magneton nuclear, dado por

$$
\mu_{N}=\frac{e h}{4 \pi m_{P} c}
$$

sendo $e$ a carga do elétron, $m_{P}$ a massa do próton e $c$ a a velocidade da luz no vácuo. De 2.7 e 2.6 podemos concluir que $\gamma \hbar=g_{N} \mu_{N}$.

\subsubsection{Spin nuclear em um campo magnético estático}

Na ausência de um campo magnético externo, os dois autoestados do próton, com $m_{I}=\frac{1}{2}$ e $m_{I}=-\frac{1}{2}$, possuem mesma energia, ou seja, 
são degenerados. Na presença de um campo magnético externo $\overrightarrow{B_{0}}$, esta degenerescência é quebrada, uma vez que há interação entre o momento magnético nuclear $(\vec{\mu})$ e o campo magnético externo $\left(\overrightarrow{B_{0}}\right)$, a interação Zeeman. O Hamiltoniano desta interação é dado por:

$$
H=-\vec{\mu} \cdot \overrightarrow{B_{0}} .
$$

Podemos considerar a direção de $\overrightarrow{B_{0}}$ como a direção do eixo $z$, assim $\overrightarrow{B_{0}}=B_{0} \vec{k}$, e o Hamiltoniano passa a ser dado pela equação:

$$
H=-\mu_{z} B_{0} .
$$

A partir das equações 2.5, 2.6 e 2.10, concluímos que:

$$
H=-\gamma B_{0} I_{z}
$$

Assim, os autovalores deste hamiltoniano são múltiplos dos autovalores de $I_{z}$, e as energias de interação do núcleo com o campo magnético $\overrightarrow{B_{0}}$ são dadas pela equação de Schrödinger:

$$
-\gamma B_{0} \hat{I}_{z} \psi_{N}=-\gamma B_{0} \hbar m_{I} \psi_{N}
$$

Os valores possíveis de energia observados são portanto:

$$
E=-\gamma \hbar B_{0} m_{I}
$$

A diferença de energia entre os dois autoestados do próton então é dada por:

$$
\Delta E=\gamma \hbar B_{0} .
$$

Uma vez que a regra de seleção para transições de spin nuclear permite apenas transições em que

$$
\Delta m_{I}= \pm 1
$$

a diferença de energia entre dois níveis consecutivos em um núcleo com spin maior que $1 / 2$ também é dada pela equação 2.14 .

\subsubsection{Transições entre níveis de energia}

Em um experimento de ressonância típico o número de núcleos submetidos ao campo magnético $\overrightarrow{B_{0}}$ é da ordem de $10^{23}$. Estes núcleos ocupam os dois níveis de energia, e transições entre os dois estados são possíveis desde que ocorra emissão ou absorção 
(a)
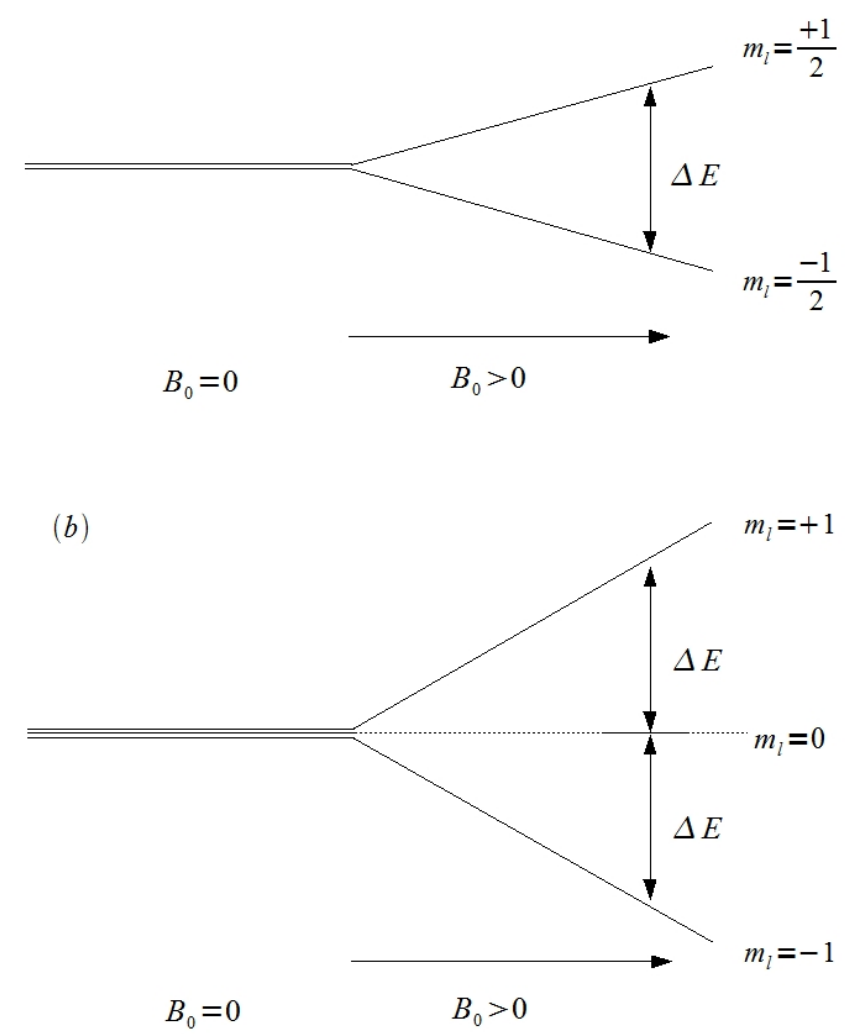

Figura 2.3: (a) Níveis de energia de um núcleo com spin igual a $1 / 2$. (b) Níveis de energia de um núcleo com spin igual a 1.

de um valor de energia igual a $\Delta E$. De acordo com a condição de frequência de Bohr, $\Delta E=h \nu$, podemos ver que para que ocorram transições entre os estados é necessário haver absorção ou emissão de um quantum de energia (Equação 2.16) ou de radiação com frequência conhecida $\nu$.

$$
h \nu_{0}=\gamma \hbar B_{0}
$$

Considerando-se as equações 2.14 e 2.16, para núcleos de spin igual a meio, a frequência do fóton para que haja transição entre os estados de spin é dada por:

$$
\nu_{0}=\frac{\gamma B_{0}}{2 \pi} \quad \text { ou } \quad \omega_{0}=\gamma B_{0} \quad(\text { considerando-se } \omega=2 \pi \nu) .
$$


As equações 2.16 e 2.17 são equivalentes e determinam a condição de ressonância de um sistema, em que a frequência de radiação equivale à diferença de energia entre os dois estados. A frequência $\nu_{0}$ também é chamada frequência de Larmor. Para prótons, que possuem $\gamma_{H}=2,674 \cdot 10^{8} \mathbf{T}^{-1} \mathbf{s}^{-1}$, um campo magnético de 1,4 T corresponde a uma frequência de ressonância de $60 \mathrm{MHz}$. Esta frequência corresponde a um comprimento de onda $\lambda$ de $5 \mathrm{~m}$, comprimento típico de ondas de rádio. $O$ fato de se utilizar de radiação nesta faixa de frequência torna a ressonância magnética nuclear um método seguro, em especial para práticas em medicina, uma vez que não se utiliza radiação ionizante.

A condição de ressonância (Equação 2.17) pode ser atingida quando variamos o valor da frequência $\nu$ da radiação eletromagnética enquanto mantemos o valor do campo magnético $B_{0}$ fixo, ou modificando-se o valor de campo $B_{0}$ enquanto mantemos a frequência $\nu$ fixa. Inicialmente, os espectrômetros de ressonância magnética utilizavam uma técnica conhecida como espectroscopia de onda contínua ( $\mathrm{CW}$ - continuous wave spectroscopy), em que variavam continuamente ou o campo magnético ou a frequência da radiação eletromagnética. Embora seja possível obter um espectro de RMN de ambas as maneiras, é mais viável a construção de espectrômetros em que a frequência da radiação é mantida constante e o campo magnético varia com a variação da corrente aplicada a um eletromagneto. Nos espectrômetros mais recentes, o campo $B_{0}$ é mantido fixo e se aplica um pulso de radiofrequência, método conhecido como espectroscopia de onda pulsada.

\subsubsection{Magnetização Resultante}

A condição de Bohr (equação 2.17) é apenas uma condição necessária para que haja transições entre níveis de energia consecutivos, induzindo transições ascendentes (absorção de energia) e descendentes (emissão de energia) com a mesma probabilidade. Para que se possa observar absorção ou emissão líquida de energia pela amostra é necessário que haja populações diferentes nos níveis energéticos. Uma amostra macroscópica é constituída por um ensemble de núcleos idênticos distribuídos nos diferentes níveis de energia de acordo com a distribuição de Boltzmann. Considerando-se novamente apenas núcleos com $I=1 / 2$, a razão entre as populações de núcleos no estado fundamental e no estado excitado é dada pela 
equação 2.18 .

$$
\frac{N_{-}}{N+}=e^{-\frac{\Delta E}{k T}}=e^{-\frac{\gamma \hbar B_{0}}{k T}} .
$$

onde $N_{+}$e $N_{-}$são o número de núcleos no estado fundamental $\left(m_{I}=-1 / 2\right)$ e no estado excitado $\left(m_{I}=1 / 2\right)$, respectivamente, k é a constante de Boltzmann, $1,3805 \cdot 10^{-23} \mathbf{J} / \mathbf{K}$ e $\mathbf{T}$ é a temperatura em Kelvin. Uma vez que a diferença de energia entre os dois níveis, $\Delta E$, é tipicamente muito pequena, podemos aproximar a equação 2.18 para:

$$
\frac{N_{-}}{N_{+}} \approx 1-\frac{\Delta E}{k T} .
$$

Temos que o número de núcleos no estado de menor energia é ligeiramente maior que o número de núcleos no estado excitado $\left(N_{+} \geq N_{-}\right)$. A diferença de população nos dois estados energéticos é dada por:

$$
N_{+}-N-=\frac{N \Delta E}{2 k T}=\frac{N h \nu}{2 k T},
$$

sendo $N$ o número total de spins da amostra, dado pela soma das populações do estado fundamental e no estado excitado $\left(N=N_{-}+\right.$ $N_{+}$). Esta diferença de população cria uma magnetização resultante $\overrightarrow{M_{0}}$ paralela ao campo $\overrightarrow{B_{0}}$ (Figura 2.4 ), com intensidade dada por

$$
M_{0}=\left(N_{+}-N_{-}\right) \mu_{z} .
$$

No caso de núcleos com spin $1 / 2$, como o próton, e usando as equações 2.6 e 2.20, a intensidade da magnetização resultante será dada por

$$
M_{0}=\left(N_{+}-N_{-}\right) \frac{1}{2} \gamma \hbar=(\gamma \hbar)^{2} \frac{N B_{0}}{4 k T} .
$$

A equação 2.22 traz informações importantes a respeito da sensibilidade dos experimentos de RMN. O fator $\gamma$ elevado ao quadrado em $M_{0}$ implica que núcleos com maior frequência de ressonância apresentarão sinais de RMN relativamente intensos. O Hidrogênio possui o maior valor de gamma entre os núcleos normalmente encontrados, apresentando então maior intensidade relativa de sinal. A dependência linear de $M_{0}$ em $B_{0}$ implica que quanto maior a intensidade do campo magnético $B_{0}$, maior a magnetização resultante e o sinal obtido. Assim, há uma tendência de se utilizar magnetos mais potentes nos aparelhos de RMN mais modernos. Por fim, o fato de $M_{0}$ ser inversamente proporcional à temperatura indica 


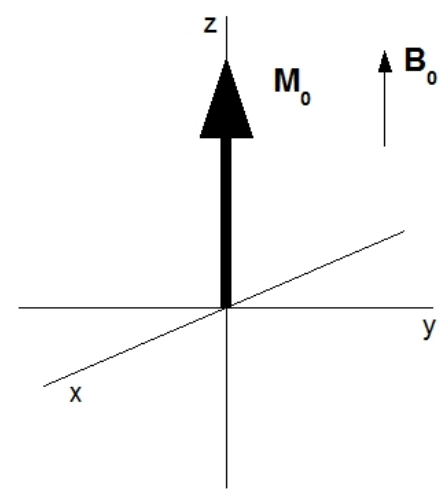

Figura 2.4: Vetor Magnetização Resultante.

que a sensibilidade pode ser aumentada com a diminuição da temperatura da amostra. De fato, a real sensibilidade experimental é determinada por muitos outros fatores, como o volume da amostra, a abundância natural do núcleo em estudo, ruído etc. A tabela 2.1 resume a sensibilidade relativa dos núcleos mais frequentemente utilizados em experimentos de RMN.

Em um campo magnético de 1,0 $\mathbf{T}$, à temperatura ambiente, o excesso de população no estado fundamental é da ordem de partes por milhão, para o núcleo de ${ }^{1} H$ valendo cerca de 7 núcleos por milhão. Nesta situação, a probabilidade de haver transições do estado fundamental para o estado excitado é extremamente baixa. Assim, experimentos de espectroscopia por RMN apresentam sensibilidade baixa, e os sinais observados são de intensidade muito menor que os sinais observados em outros tipos de espectroscopia, como a espectroscopia eletrônica de absorção e a ressonância paramagnética eletrônica (EPR - Eletronic Paramagnetic Resonance), em que a diferença de população entre os estados energéticos é muito maior.

Uma vez atingida a condição de ressonância, ocorre absorção de energia e transições para o autoestado de maior energia. Transições entre os dois autoestados do próton $\left(m_{I}=\frac{1}{2}\right.$ e $\left.m_{I}=-\frac{1}{2}\right)$ podem ocorrer com absorção ou emissão de energia, e tais transições ocorrem com a mesma probabilidade. Quando incidimos radiação na frequência de ressonância com potência suficiente, as populações nos dois autoestados se tornem iguais, e não se pode mais observar absorção de energia. Assim, não se observa mais sinal de RMN, e 


\begin{tabular}{|c|c|c|c|c|c|}
\hline Isótopo & Spin & $\begin{array}{c}\gamma \\
\left(10^{7} \mathrm{rad}^{-1} \mathrm{~T}^{-1}\right)\end{array}$ & $\begin{array}{c}\nu \\
(\mathrm{MHz})\end{array}$ & $\begin{array}{c}\text { Abundância } \\
\text { Natural (\%) }\end{array}$ & $\begin{array}{c}\text { Sensibilidade } \\
\text { Relativa }\end{array}$ \\
\hline${ }^{1} \mathrm{H}$ & $1 / 2$ & 26,752 & 100,000 & 99,985 & 1,00 \\
\hline${ }^{2} \mathrm{H}$ & 1 & 4,107 & 15,351 & 0,015 & $1,45 \times 10^{-6}$ \\
\hline${ }^{13} \mathrm{C}$ & $1 / 2$ & 6,728 & 25,145 & 1,108 & $1,76 \times 10^{-4}$ \\
\hline${ }^{14} \mathrm{~N}$ & 1 & 1,934 & 7,228 & 99,630 & $1,01 \times 10^{-3}$ \\
\hline${ }^{15} \mathrm{~N}$ & $1 / 2$ & $-2,712$ & 10,137 & 0,370 & $3,85 \times 10^{-6}$ \\
\hline${ }^{19} \mathrm{~F}$ & $1 / 2$ & 25,181 & 94,094 & 100,000 & 0,833 \\
\hline${ }^{23} \mathrm{Na}$ & $3 / 2$ & 7,080 & 26,466 & 100,000 & $9,27 \times 10^{-2}$ \\
\hline${ }^{31} \mathrm{P}$ & $1 / 2$ & 10,841 & 40,481 & 100,000 & $6,65 \times 10^{-2}$ \\
\hline${ }^{39} \mathrm{~K}$ & $3 / 2$ & 1,250 & 4,672 & 93,100 & $4,75 \times 10^{-4}$ \\
\hline
\end{tabular}

Tabela 2.1: Sensibilidade relativa dos núcleos mais frequentemente utilizados em experimentos de RMN. $\gamma$ se refere à razão giromagnética do núcleo em questão. $\nu$ se refere à frequência de ressonância do núcleo em questão em um campo $B_{0}$ de 2,35 T.

dizemos que a amostra foi saturada. O sistema deixa a condição de equilíbrio térmico encontrada antes da aplicação da onda de rf. Para que seja possível a realização de novas medidas, é preciso que o sistema retorne ao equilíbrio térmico para depois aplicarmos uma nova onda de rf. Este processo de retorno ao estado de equilíbrio é chamado de relaxação.

\subsection{Tratamento clássico}

\subsubsection{Descrição clássica}

Mesmo tratando-se de um fenômeno quântico, é possível interpretar a ressonância magnética classicamente. Um núcleo dotado de spin pode ser tratado classicamente como uma carga girante, ou uma corrente percorrendo um caminho circular fechado. Assim, o núcleo pode ser tratado como um dipolo magnético $\vec{\mu}$ dado por:

$$
\mu=j \pi r^{2}
$$

onde $j$ representa a corrente e $r$ o raio do caminho percorrido pela corrente. Uma carga de $q / c$ Coulombs girando com frequência $\nu$ voltas por segundo gera uma corrente i:

$$
j=\frac{5 q v}{\pi r c} \text { Ampères. }
$$


Assim, momento magnético $\mu$ é dado por

$$
\mu=\frac{5 q v r}{c} .
$$

Se o núcleo em questão possui massa $M$, haverá um momento angular $\vec{L}$ associado ao spin nuclear dado por:

$$
\vec{L}=M \vec{v} \times \vec{r} .
$$

O momento angular $\vec{L}$ e o momento magnético $\vec{\mu}$ são proporcionais, relacionados por:

$$
\vec{\mu}=\frac{5 q}{M c} \vec{L} .
$$

O fator de proporcionalidade entre $\vec{\mu}, r, \vec{L}$ e $5 q / M c$, é uma propriedade característica da cada núcleo, chamada de razão giromagnética nuclear $\gamma$.

Quando submetemos uma partícula carregada dotada de spin a um campo magnético externo estático e homogêneo $\overrightarrow{B_{0}}$, esta sofre a ação de um torque $\vec{T}$, que tenta modificar seu momento angular e seu momento magnético, de acordo com a equação 2.28 .

$$
\vec{T}=\frac{\partial \vec{L}}{\partial t}=\vec{\mu} \times \overrightarrow{B_{0}} \quad \text { ou } \quad \frac{\gamma \partial \vec{L}}{\partial t}=\frac{\partial \vec{\mu}}{\partial t}=\vec{\mu} \times\left(\gamma \overrightarrow{B_{0}}\right)
$$

Nesta situação, o momento magnético do núcleo passa a precessar em torno do eixo $z$, com velocidade angular $\omega_{0}$ proporcional ao campo $\overrightarrow{B_{0}}$ :

$$
\overrightarrow{\omega_{0}}=\gamma \overrightarrow{B_{0}}
$$

ou analogamente podemos dizer que o núcleo passa a precessionar em torno do eixo $z$ com frequência igual a $\nu$ :

$$
\nu=\frac{\omega}{2 \pi}=\frac{\gamma B_{0}}{2 \pi} .
$$

A frequência $\nu$ é conhecida como frequência de Larmor, e não depende do ângulo $\theta$ entre o momento angular do núcleo, $\vec{L}$, e o campo magnético $\overrightarrow{B_{0}}$.

Classicamente, os dois autoestados de um núcleo com $I=1 / 2$, como o núcleo de ${ }^{1} \mathrm{H}$, podem ser representados pela orientação da componente $z$ do vetor momento magnético nuclear, $\mu_{z}$, em relação ao campo $\overrightarrow{B_{0}}$, sendo que nos dois níveis de energia o ângulo $\theta$ entre o momento magnético $\vec{\mu}$ e o eixo $z$ é o mesmo. O autoestado de menor 
energia corresponde à situação em que $\vec{\mu}$ está orientado a favor do campo magnético $\overrightarrow{B_{0}}$ (orientação paralela), e o autoestado de maior energia corresponde à situação em que $\vec{\mu}$ se orienta contra o campo magnético $\overrightarrow{B_{0}}$ (orientação anti-paralela). Neste modelo, a absorção de energia leva à inversão da orientação do momento magnético $\vec{\mu}$, quando tratado isoladamente.

Uma amostra macroscópica é composta por um ensemble de núcleos idênticos distribuídos entre os níveis de energia de acordo com a distribuição de Boltzmann. Para uma amostra contendo núcleos com spin igual a $1 / 2$, haverá uma população ligeiramente maior de núcleos no nível fundamental, ou seja, orientados a favor do campo magnético $\overrightarrow{B_{0}}$. Definimos a magnetização macroscópica, ou magnetização resultante, como a soma dos $i$ momentos magnéticos dos núcleos da amostra, dada por:

$$
\vec{M}=\sum_{i} \overrightarrow{\mu_{i}}
$$

Na presença do campo magnético $\overrightarrow{B_{0}}$, os momentos magnéticos $\overrightarrow{\mu_{i}}$ tendem a se orientar preferencialmente a favor do campo, na condição de menor energia, havendo um pequeno excesso na população de spins orientada a favor de $\overrightarrow{B_{0}}$. Além disso, os momentos magnéticos $\overrightarrow{\mu_{i}}$ apresentam fase arbitrária, com o ângulo $\Phi_{i}$ entre a projeção de $\overrightarrow{\mu_{i}}$ no plano $x y$ e o eixo $x$ distribuído aleatoriamente. Assim, as componentes $\boldsymbol{x}$ e $\boldsymbol{y}$ dos momentos magnéticos se cancelam, fazendo com que a magnetização resultante $\vec{M}$ seja um vetor estático sobre o eixo $z$, paralelo a $B_{0}$ e com magnitude constante (Figura 2.5).

Se aplicarmos um campo magnético secundário $\overrightarrow{B_{1}}$ ao sistema, a $90^{\circ}$ do campo magnético inicial, $\overrightarrow{B_{0}}$, ou seja, no plano $x y$, em um ponto da trajetória de precessão o momento magnético de dipolo sofrerá ação conjunta dos dois campos magnéticos, $\overrightarrow{B_{0}}$ e $\overrightarrow{B_{1}}$. Esta ação conjunta tende a provocar uma alteração $\delta \theta$ no valor do ângulo $\theta$ entre o vetor momento magnético $\vec{\mu}$ e o eixo $z$. No ponto diametralmente oposto na trajetória de precessão, a combinação de $\overrightarrow{B_{0}}$ e $\overrightarrow{B_{1}}$ tenderá a provocar uma alteração de $-\delta \theta$ no ângulo entre $\vec{\mu}$ e o eixo $z$. Podemos concluir então que se $\overrightarrow{B_{1}}$ for um campo estático no plano $x y$ ele não provocará nenhuma modificação na orientação de $\vec{\mu}$, e portanto não haverá nenhuma modificação líquida da energia do sistema.

Para que o campo $\overrightarrow{B_{1}}$ possa provocar alterações na energia do 


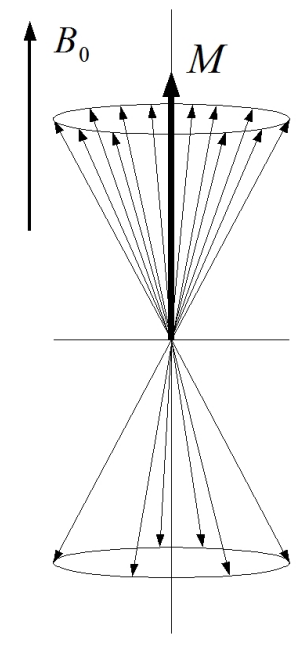

Figura 2.5: Momentos magnéticos da amostra e Magnetização resultante.

sistema ele deve acompanhar o movimento de rotação de $\vec{\mu}$, ou seja, o campo $\overrightarrow{B_{1}}$ deve girar no plano $x y$ com a velocidade angular dada pela frequência de Larmor, $\omega=2 \pi \nu$. Quando o campo $\overrightarrow{B_{1}}$ gira em torno do eixo $z$ com a frequência de Larmor dizemos que foi atingida a condição de ressonância do sistema.

Na prática, o campo magnético girante é criado por um oscilador ao longo do eixo $x$ ou do eixo $y$, que cria um campo magnético linearmente polarizado com velocidade angular $\omega$ e amplitude $2 B_{1}$, dado por:

$$
\overrightarrow{B_{x}}=2 B_{1} \cos (\omega t) \vec{i}
$$

no caso de um campo linearmente polarizado sobre o eixo $x$. Este campo linearmente polarizado pode ser representado por dois campos magnéticos girantes com sentidos de rotação opostos, um deles girando no sentido horário e outro girando no sentido anti-horário. A componente do campo que gira na mesma direção que os momentos magnéticos tem ação sobre o sistema, enquanto a componente que gira na direção oposta pode ser descartada, pois não atua sobre o sistema.

\subsubsection{Equações de Bloch}

Na condição de ressonância haverá absorção de energia de $\overrightarrow{B_{1}}$ e modificação no valor do ângulo $\theta$ entre $\vec{\mu}$ e o eixo $z$, sendo que 
a variação do ângulo dependerá da intensidade de $\overrightarrow{B_{1}}$ e do tempo durante o qual este campo é aplicado. Assim, a magnetização resultante $\vec{M}$ deixa de ser um vetor estático sobre o eixo $z$ e passa e precessar em torno dos campos $\overrightarrow{B_{0}}$ e $\overrightarrow{B_{1}}$ simultaneamente.

A variação de $\vec{M}$ em função do tempo é descrita por um conjunto de equações desenvolvidas por Bloch, conhecidas como as equações de Bloch. A partir da equação 2.28, para a soma sobre os $i$ momentos magnéticos $\vec{\mu}$, temos que:

$$
\frac{\partial \vec{M}}{\partial t}=\gamma \vec{M} \times \vec{B}
$$

onde $\vec{B}$ corresponde ao campo magnético total ao qual a amostra foi submetida, ou seja, $\overrightarrow{B_{0}}+\overrightarrow{B_{1}}$. A equação 2.33 pode ser desenvolvida em suas componentes $x, y$ e $z$ :

$$
\frac{\partial \vec{M}}{\partial t}=\gamma\left[\left(M_{y} B_{z}-M_{z} B_{y}\right) \vec{i}+\left(M_{z} B_{x}-M_{x} B_{z}\right) \vec{j}+\left(M_{x} B_{y}-M_{y} B_{x}\right) \vec{k}\right] .
$$

As componentes de $\vec{B}$ são dadas por:

$$
\begin{aligned}
& \overrightarrow{B_{x}}=B_{1} \cos (\omega t) \\
& \overrightarrow{B_{y}}=B_{1} \operatorname{sen}(\omega t) \\
& \overrightarrow{B_{z}}=B_{0}
\end{aligned}
$$

assim a equação 2.34 pode ser reescrita como três equações:

$$
\begin{aligned}
\frac{\partial M_{x}}{\partial t} & =\gamma\left(M_{y} B_{0}+M_{z} B_{1} \operatorname{sen}(\omega t)\right) \\
\frac{\partial M_{y}}{\partial t} & =\gamma\left(M_{z} B_{1} \cos (\omega t)-M_{x} B_{0}\right) \\
\frac{\partial M_{z}}{\partial t} & =-\gamma\left(M_{x} B_{1} \operatorname{sen}(\omega t)+M_{y} B_{1} \cos (\omega t)\right) .
\end{aligned}
$$

Estas equações não levam em consideração os efeitos de relaxação, responsáveis pelo retorno do sistema à condição de equilíbrio térmico após a aplicação da perturbação $\overrightarrow{B_{1}}$. Os mecanismos de relaxação são processos de primeira ordem que tendem a restaurar a magnetização resultante ao valor inicial. Assim, $M_{x}$ e $M_{y}$ devem voltar ao valor inicial, zero, e $M_{z}$ deve voltar ao valor inicial, $M_{0}$. Incluindo estes efeitos nas equações de Bloch encontramos a forma completa destas equações: 


$$
\begin{aligned}
\frac{\partial M_{x}}{\partial t} & =\gamma\left(M_{y} B_{0}+M_{z} B_{1} \operatorname{sen}(\omega t)\right)-\frac{M_{x}}{T_{2}} \\
\frac{\partial M_{y}}{\partial t} & =\gamma\left(M_{z} B_{1} \cos (\omega t)-M_{x} B_{0}\right)-\frac{M_{y}}{T_{2}} \\
\frac{\partial M_{z}}{\partial t} & =-\gamma\left(M_{x} B_{1} \operatorname{sen}(\omega t)+M_{y} B_{1} \cos (\omega t)\right)-\frac{M_{z}-M_{0}}{T_{1}} .
\end{aligned}
$$

Uma vez que $T_{1}$ é a constante de tempo que determina o retorno da componente da magnetização paralela ao eixo $z$ e ao campo $\overrightarrow{B_{0}}$, esta constante é chamada de tempo de relaxação longitudinal. A constante de tempo $T_{2}$ por sua vez é chamada de tempo de relaxação transversal, pois descreve o decaimento da magnetização no plano $x y$.

\subsubsection{O referencial girante}

A maioria dos espectrômetros modernos funciona com aplicação de pulsos de rf como perturbação e examinam o decaimento da magnetização da amostra em função do tempo. Tal decaimento é ilustrado de maneira mais intuitiva através do tratamento clássico do fenômeno de RMN. Para que seja possível resolver as equações de Bloch nestas condições é usual passarmos do sistema de coordenadas fixo, do laboratório, para um sistema de coordenadas que gire em torno de $\overrightarrow{B_{0}}$ no mesmo sentido e com a mesma velocidade angular que o campo magnético secundário $\overrightarrow{B_{1}}$. Este referencial é conhecido como referencial girante, com eixo $z$ fixo e sobreposto ao referencial do laboratório, e eixos $x$ e $y$ girantes, com velocidade angular igual à frequência de precessão dos núcleos, $\omega_{0}$ (frequência de Larmor). Neste caso, temos que:

$$
\left(\frac{\partial \overrightarrow{\mu_{i}}}{\partial t}\right)_{\text {girante }}=\left(\frac{\partial \overrightarrow{\mu_{i}}}{\partial t}\right)_{\text {fixo }}-\vec{\omega} \times \overrightarrow{\mu_{i}}
$$

considerando que o subscrito "girante"se refere ao referencial girante com velocidade angular $\vec{\omega}$, e o subscrito "fixo"se refere ao referencial do laboratório. Considerando a equação 2.28, temos que:

$$
\left(\frac{\partial \overrightarrow{\mu_{i}}}{\partial t}\right)_{\text {girante }}=\gamma \overrightarrow{\mu_{i}} \times \overrightarrow{B^{\prime}}
$$


ou seja, no referencial girante o campo magnético inicial $\overrightarrow{B_{0}}$ passa a ser $\overrightarrow{B^{\prime}}$, dado por:

$$
\overrightarrow{B^{\prime}}=\overrightarrow{B_{0}}-\frac{\vec{\omega}}{\gamma}
$$

e os momentos magnéticos precessam em torno de $B^{\prime}$ com velocidade angular $\gamma \overrightarrow{B^{\prime}}$. Se $\vec{\omega}=\gamma \overrightarrow{B_{0}}$, temos que $\overrightarrow{B^{\prime}}$ se anula. Nesta situação, temos que os $i$ vetores momento magnético $\overrightarrow{\mu_{i}}$ assumem uma posição fixa no referencial girante. Com esta mudança de referencial, temos que a magnetização resultante $\vec{M}$ é invariante, ou seja, continua a ser um vetor estático sobre o eixo $z$.

Para que o sistema atinja a condição de ressonância, um segundo campo magnético, o campo $\overrightarrow{B_{1}}$, deve agir sobre o sistema. O campo $\overrightarrow{B_{1}}$ deve estar orientado a $90^{\circ}$ da componente de $\vec{\mu}$ no plano $z$, e deve girar no plano $x y$ com a mesma velocidade angular da frequência de Larmor. O efeito de $\overrightarrow{B_{1}}$ sobre o sistema é mais facilmente visualizado no referencial girante, em que o campo oscilante pode ser tratado como um campo estático.

Quando campo magnético $\overrightarrow{B_{1}}$ incide sobre o sistema, de modo que seja estacionário no referencial girante, temos que o campo efetivo será dado por:

$$
B_{e f}=B^{\prime}+B_{1}=B_{0}-\frac{\omega}{\gamma}+B_{1}=B_{0}\left(1-\omega / \omega_{0}\right)+B_{1},
$$

em que $\omega_{0}$ se refere à frequência de Larmor. O ângulo $\phi$ formado entre o campo $\overrightarrow{B_{e f}}$ e o eixo $z$ (Figura 2.6) é dado por:

$$
\tan \phi=B_{1} /\left[B_{0}\left(1-\omega / \omega_{0}\right)\right]
$$

Considerando que $B_{0}$ é muito maior que $B_{1}$, temos que, se $\omega_{0}$ e $\omega$ possuírem magnitudes muito diferentes, o campo efetivo se alinha paralelamente ao eixo $z$, uma vez que $\tan \phi$ se aproxima de zero ( $\phi \approx 0^{\circ}$ ou $\phi \approx 180^{\circ}$ para $\omega_{0}<\omega$ ou $\omega_{0}>\omega$, respectivamente). Nesta situação, os momentos magnéticos $\overrightarrow{\mu_{i}}$ que no referencial do laboratório precessionavam em torno do eixo $z$ continuam neste movimento, porém com a sua órbita alterada devido à ação de $\overrightarrow{B_{1}}$ (nutação). No entanto, se $\omega_{0} \approx \omega, \tan \phi$ se aproxima de infinito, e $\phi=90^{\circ}$. Nesta situação, $\overrightarrow{B_{e f}}=\overrightarrow{B_{1}}$ e os momentos magnéticos $\overrightarrow{\mu_{i}}$ passam a precessar em torno de $\overrightarrow{B_{1}}$ com frequência $\omega$, e dizemos que o sistema atingiu a condição de ressonância.

Quando atingimos a condição de ressonância, temos que: 


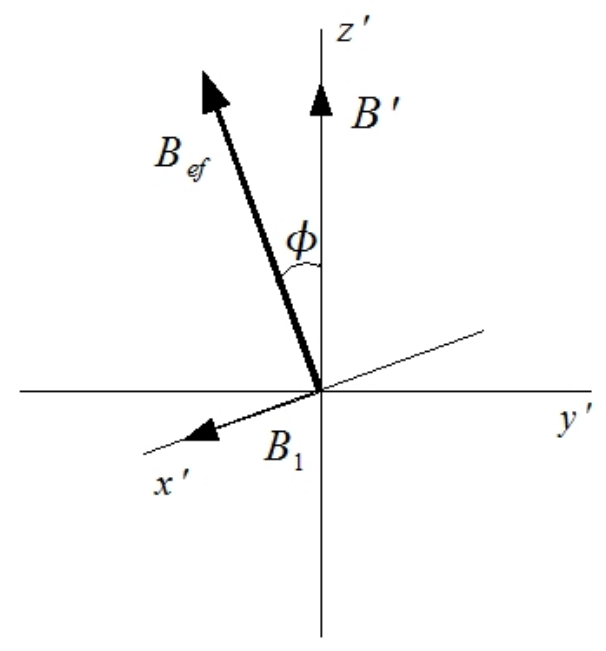

Figura 2.6: Campo efetivo sobre a amostra no referencial girante.

$$
\omega=\omega_{0}=-\gamma B_{0}
$$

Nesta situação, no referencial girante, o ângulo $\Phi$ entre a magnetização macroscópica, $\vec{M}$, e o eixo $z$ passa a aumentar, ou seja, a magnetização $\vec{M}$ passa a precessar em torno do $\overrightarrow{B_{1}}$ com frequência angular $\omega_{1}$ igual a $\gamma B_{1}$ (Figura 2.7). Após um tempo $t_{p}$ a magnetização $\vec{M}$ percorreu um ângulo $\Phi$ dado por:

$$
\Phi=\gamma \overrightarrow{B_{1}} t_{p}
$$

No referencial girante, as equações de Bloch passam a ser dadas por:

$$
\begin{aligned}
\frac{\partial M_{x}^{\prime}}{\partial t} & =\left(\omega_{0}-\omega\right) M_{y}^{\prime}-\frac{M_{x}^{\prime}}{T_{2}} \\
\frac{\partial M_{y}^{\prime}}{\partial t} & =-\left(\omega_{0}-\omega\right) M_{x}^{\prime}+\gamma B_{1} M_{z}^{\prime}-\frac{M_{y}^{\prime}}{T_{2}} \\
\frac{\partial M_{z}^{\prime}}{\partial t} & =-\gamma B_{1} M_{y}^{\prime}-\frac{M_{z}^{\prime}-M_{0}}{T_{1}} .
\end{aligned}
$$



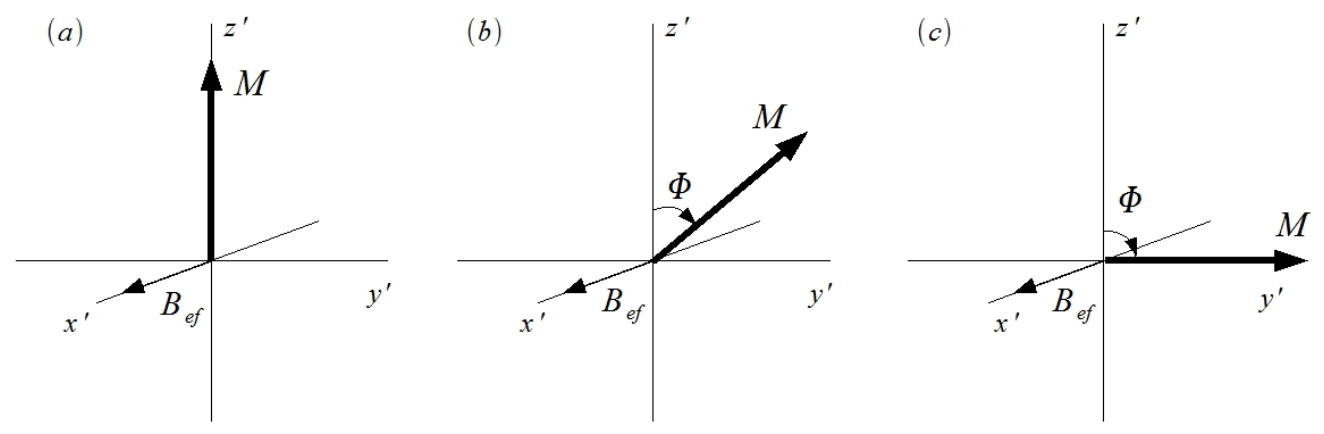

Figura 2.7: Magnetização resultante $\vec{M}$ sob efeito do campo magnético $\overrightarrow{B_{e f}}=\overrightarrow{B_{1}}$ no referencial girante. (a) No instante em que o campo $\overrightarrow{B_{1}}$ foi aplicado. (b) Após tempo $t_{p 1}$ o ângulo $\Phi$ entre a magnetização $\vec{M}$ e o eixo $z$ aumenta. (c) Após um tempo $t_{p 2}$ o ângulo $\Phi$ vale $90^{\circ}$.

\subsubsection{Excitação}

Em RMN, a direção da magnetização macroscópica é usualmente alterada aplicando-se um campo oscilante de radiofrequência por um tempo curto $\delta t$, ao que se dá o nome de pulso de excitação. A duração e a intensidade deste pulso determinam o ângulo $\Phi$ entre a magnetização $\vec{M}$ e o eixo $z$ no referencial girante (Equação 2.44) - Por exemplo, a duração do pulso de radiofrequência pode ser escolhida de modo que $\Phi$ seja $90^{\circ}$, ou seja, a magnetização $\vec{M}$ passe a se posicionar sobre o plano $x$ - $y$, situação conhecida como pulso de $90^{\circ}$. Variando a duração do pulso em questão, é possível variar a posição de $\vec{M}$ (Figura 2.8).

Durante a aplicação do pulso de excitação, a magnetização resultante precessa em torno dos campos $\overrightarrow{B_{0}}$ e $\overrightarrow{B_{1}}$, no referencial do laboratório, passando a possuir componentes nas direções $x$ e $y$, dadas por 2.46 .

$$
\begin{aligned}
& M_{x}=M_{0} \operatorname{sen}\left(\omega_{0} t\right) \\
& M_{y}=M_{0} \cos \left(\omega_{0} t\right)
\end{aligned}
$$

As componentes $x$ ou $y$ podem ser facilmente detectadas por uma bobina receptora situada no eixo correspondente, como uma corrente elétrica senoidal.

Após o tempo de duração do pulso, $\delta t$, o campo $\overrightarrow{B_{1}}$ é desligado e o sistema tende a retornar à situação inicial, com a magnetização 

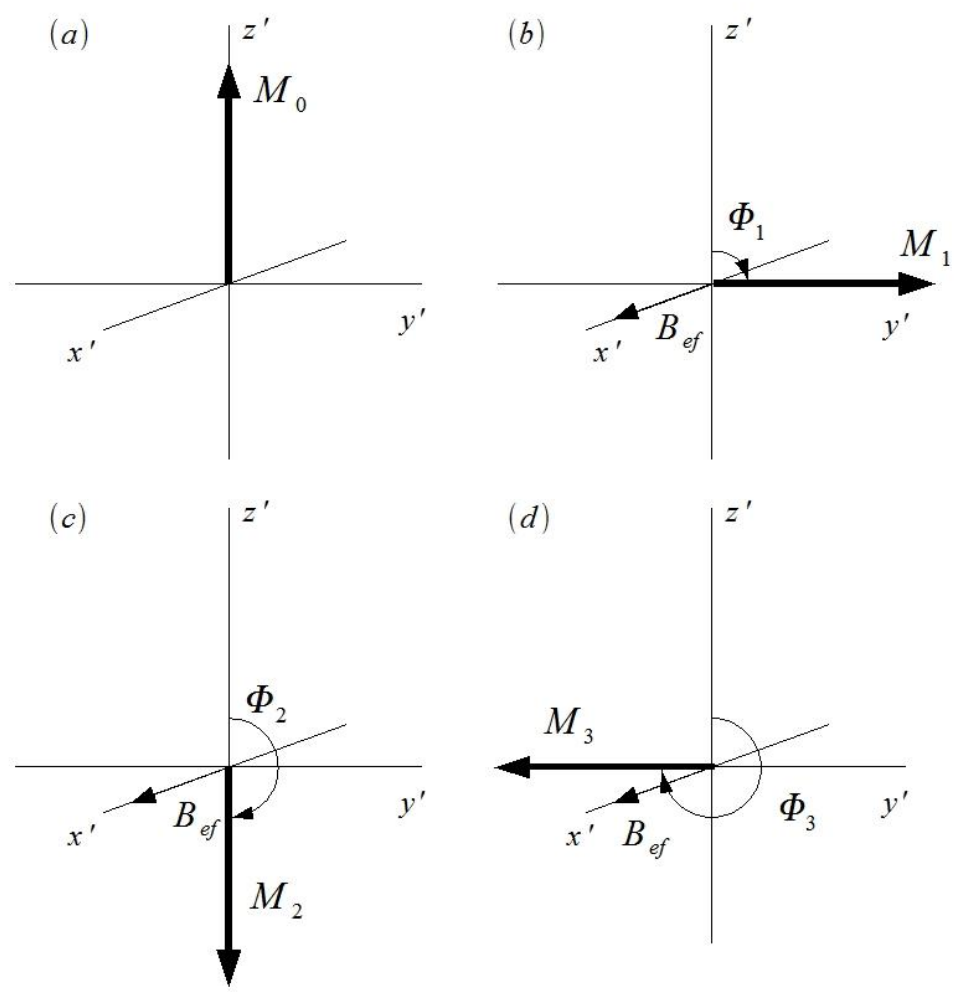

Figura 2.8: Ação de pulsos de radiofrequência sobre a magnetização $\vec{M}$ no referencial girante. (a)Magnetização no estado de equilíbrio incial, antes da aplicação do pulso. (b)Mangetização $\vec{M}_{1}$ após aplicação de um pulso de $\pi / 2$ ou $90^{\circ}$. (c)Mangetização $\vec{M}_{2}$ após aplicação de um pulso de $\pi$ ou $180^{\circ}$. (d)Mangetização $\vec{M}_{3}$ após aplicação de um pulso de $3 \pi / 2$ ou $270^{\circ}$.

$\vec{M}$ alinhada com o eixo $z$. Uma vez restabelecida a condição de equilíbrio inicial, um novo pulso de rf. é aplicado e uma nova medida é realizada. Este procedimento é repetido diversas vezes, e ao final de um número determinado de repetições é feita a média de todas as medidas. Desta maneira, o ruído pode ser minimizado, uma vez que este apresenta comportamento aleatório.

\subsection{Relaxação}

Quando aplicamos um pulso de r.f., este age como uma perturbação em nosso sistema, alterando a condição de equilíbrio térmico. No equilíbrio, o vetor magnetização resultante, se encontra sobre 
o eixo $z$, na mesma direção do campo magnético inicial $\overrightarrow{B_{0}}$, e é chamado magnetização de equilíbrio, $\vec{M}_{0}$. O módulo da componente da magnetização na direção $z, M_{z}$, é igual a $M_{0}$, e não há magnetização transversal, ou seja, as componentes no plano $x y\left(M_{x} e M_{y}\right)$ são iguais a zero. Para que a magnetização resultante volte à condição de equilíbrio após a aplicação do pulso de r.f., os núcleos excitados precisam transferir a energia absorvida, processo chamado de relaxação. Existem dois mecanismos de relaxação: relaxação spin-rede, ou relaxação longitudinal, caracterizada pela constante de tempo $T_{1}$, em que ocorre o retorno da componente $z$ da magnetização ao valor de equilíbrio devido a transferência de energia do núcleo excitado para as moléculas da rede; e relaxação spin-spin, ou relaxação transversal, caracterizada pela constante de tempo $T_{2}$, em que as componentes $x$ e $y$ da magnetização retornam ao valor de equilíbrio devido a trocas de energia entre núcleos iguais.

Tanto a relaxação longitudinal como a relaxação transversal não são processos espontâneos, mas sim provocados por campos elétricos ou magnéticos dependentes do tempo que atingem o núcleo. Estes campos são originados pelos movimentos térmicos randômicos presentes em qualquer conjunto de átomos ou moléculas. Para que possa ocorrer relaxação, os movimentos das moléculas devem ocorrer na mesma escala de tempo que as frequências características dos fenômenos de $\mathrm{RMN}(\mathrm{Hz}-\mathrm{MHz})$. O movimento de elétrons e as vibrações moleculares são muito mais rápidos que isto, portanto não influenciam nos processos de relaxação. Qualquer processo que induza transições rápidas entre os estados de spin fundamental e excitado e que varie com frequência próxima à frequência de ressonância do sistema causará relaxação. A escala de tempo da RMN é da mesma ordem dos movimentos de translação e de rotação das moléculas de um fluido. Variações de temperatura e de viscosidade alteram a movimentação das partículas, e portanto alteram os valores de $T_{1}$ e de $T_{2}$. No corpo humano, a temperatura não sofre variações significativas, entretanto a viscosidade dos tecidos varia consideravelmente, o que permite identificar tecidos diferentes pelo seu valor de $T_{1}$ ou de $T_{2}$.

Uma vez que a população de spins tenha relaxado, novos pulsos de NMR podem ser aplicados, já que a amostra voltou para o estado de equilíbrio térmico inicial. 


\section{Relaxação spin-rede ou Relaxação Longitudinal}

No processo de relaxação spin-rede, há transferência de energia para as moléculas da rede para que o núcleo em questão passe do estado excitado para o estado fundamental. O tempo de relaxação característico, $T_{1}$, depende da razão giromagnética do núcleo $(\gamma)$, da temperatura e da mobilidade das moléculas da rede. Assim, em sólidos cristalinos e líquidos viscosos, a mobilidade das moléculas na rede é baixa, e o valor de $T_{1}$ é alto. Para uma dada temperatura, quanto maior a mobilidade das moléculas na rede, menor o valor de $T_{1}$.

Durante a aplicação do pulso de excitação, o ângulo entre a magnetização resultante e o eixo $z$ é alterado, ou seja, o valor da componente $M_{z}$ da magnetização macroscópica é modificado. Depois da aplicação de um pulso de $90^{\circ}$ de excitação, a magnetização macroscópica $\vec{M}$ começa a retornar para a sua posição de equilíbrio térmico, sobre o eixo $z$ (Figura 2.9). O tempo necessário para que a componente longitudinal da magnetização, $M_{z}$, volte a seu valor de equilíbrio é o de tempo de relaxação spin-rede, ou $T_{1}$. O comportamento da componente $M_{z}$ em função do tempo é descrito pela equação 2.47 .

$$
M_{z}=M_{0}\left(1-e^{-t / T_{1}}\right)
$$

Se aplicarmos um pulso de $180^{\circ}$, a magnetização resultante passará a se posicionar sobre $-z$, e voltará para a posição inicial, sobre o eixo $+z$ de acordo com a equação a seguir.

$$
M_{z}=M_{0}\left(1-2 e^{-t / T_{1}}\right)
$$

\section{Relaxação spin-spin ou Relaxação Transversal}

No processo de relaxação spin-spin, há troca de estado de spin entre dois núcleos iguais com estados de spin diferentes. Essa troca é reversível, e para que ocorra é necessário que a diferença de energia entre os estados fundamental e excitado dos dois núcleos seja a mesma. Isto equivale a dizer que o spin no estado excitado está emitindo um fóton que é absorvido pela spin no estado fundamental. Esta troca de spins não afeta $T_{1}$, uma vez que a distribuição de spins entre os estados de maior e de menor energia não é alterada. Entretanto, este processo afeta $T_{2}$, pois a coerência de fase da magnetização transversal se perde quando há troca de spins. Isto 

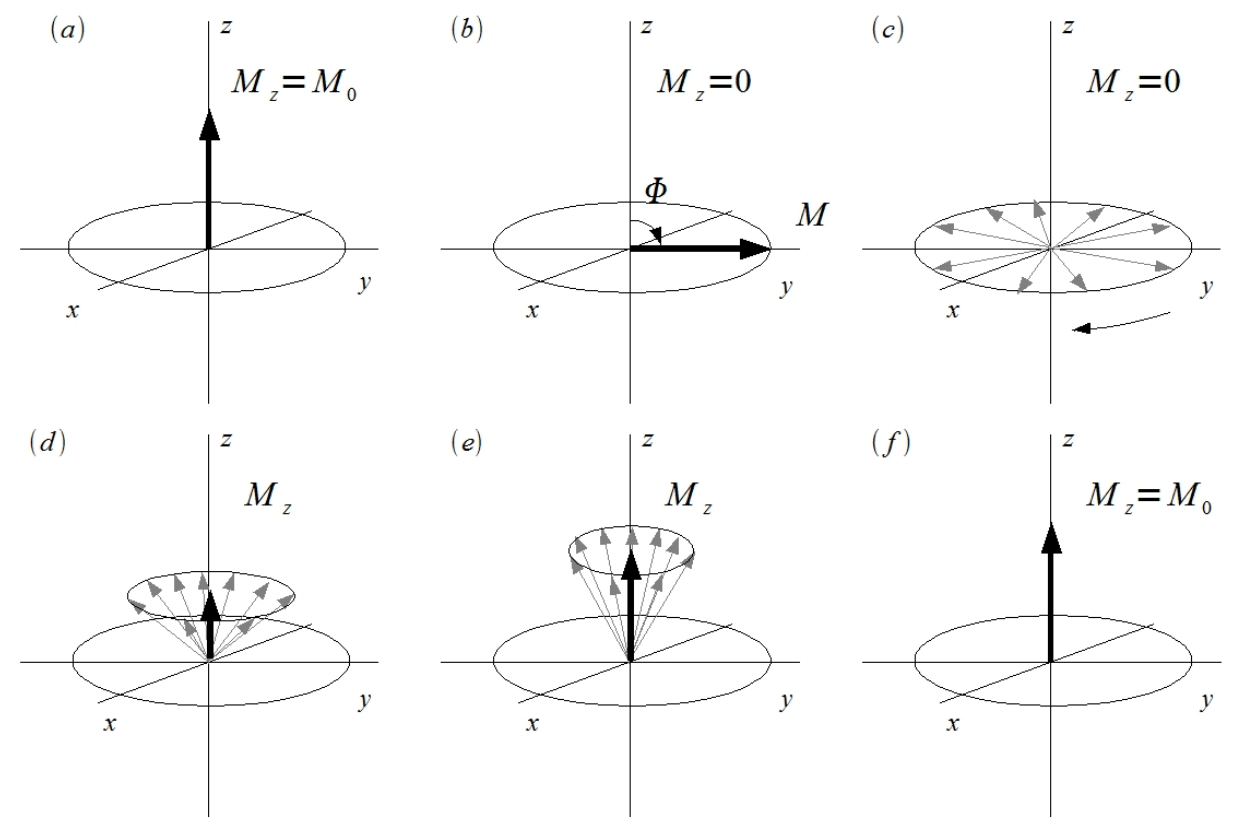

Figura 2.9: Relaxação longitudinal ou spin-rede. (a) Antes da aplicação do campo $\overrightarrow{B_{1}}$, a magnetização macroscópica é um vetor estático sobre o eixo $z$. (b) No caso de um pulso de $90^{\circ}$ a componente $z$ da magnetização macroscópica vai a zero. (c) Após um tempo $T_{2}$ há perda de coerência de fase dos spins no plano $x-y$. (d) Após um tempo maior que $T_{2}$, os spins, já sem coerência de fase, iniciam o retorno à condição de equilíbrio, alinhando-se a favor do campo magnético $\overrightarrow{B_{0}}$. (e) Gradualmente a componente $z$ da magnetização passa a se aproximar do valor inicial, $M_{0}$. (f) Após um intervalo de tempo $T_{1}$, a componente $z$ da magnetização volta ao valor de equilíbrio.

equivale a dizer que as componentes $x$ e $y$ da magnetização voltam ao valor de equilíbrio, zero.

Adicionalmente, diferentes spins presentes na amostra são submetidos a campos magnéticos ligeiramente diferentes, devido ao ambiente químico em que se encontram, e isso faz com que tais spins possuam cada um uma frequência de Larmor característica. Isso leva à perda de fase do vetor magnetização resultante, e esta defasagem aumenta com o tempo. O tempo necessário para que haja total perda de fase é constante, chamado de $T_{2}$. O comportamento das componentes $\boldsymbol{x}$ e $\boldsymbol{y}$ da magnetização resultante é função de $T_{2}$ (2.49).

$$
M_{x}=M_{0 x} e^{-t / T_{2}} \quad M_{y}=M_{0 y} e^{-t / T_{2}}
$$


Assim, a magnetização no plano $x y$ vai a zero, e começa a aumentar de intensidade sobre o eixo $z$, simultaneamente, até que o equilíbrio térmico seja atingido com a condição de que $T_{2}$ seja menor ou igual a $T_{1}$ (Figura 2.10).

O decaimento da magnetização transversal a zero é influenciado por dois fatores, as interações moleculares, responsáveis pelo efeito puramente molecular em $T_{2}$, e as inomogeneidades de $B_{0}$, responsáveis pelo efeito de variações em $T_{2}$. A combinação destes dois fatores é o que de fato leva ao decaimento da magnetização transversal. A constante de tempo que se refere a estes dois fatores é chamada de $T_{2}$ estrela, ou $T_{2}^{*}$, e é relacionada com a constante de tempo $T_{2}$ por:

$$
\frac{1}{T_{2}^{*}}=\frac{1}{T_{2}}+\gamma \Delta B_{0}
$$
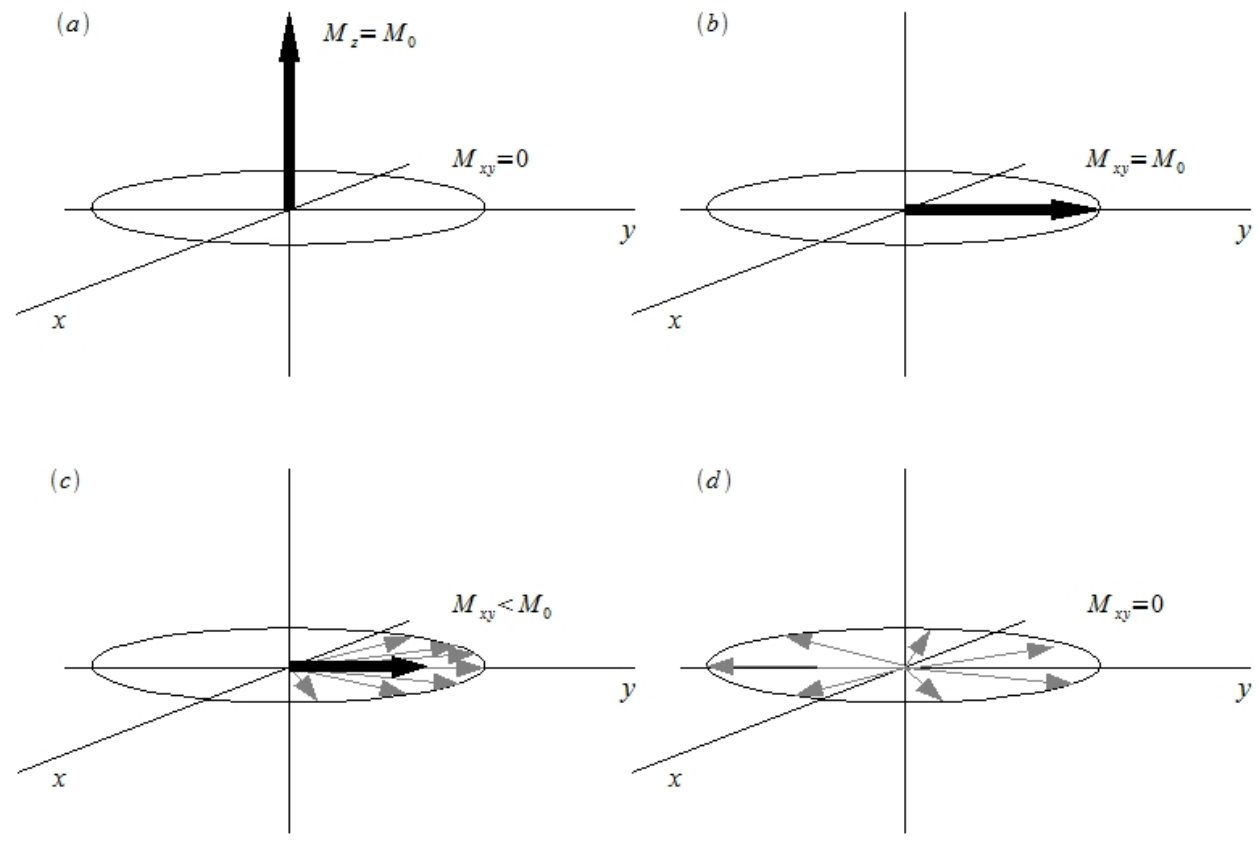

Figura 2.10: Relaxação transversal ou relaxação spin-spin.(a) Antes da aplicação do campo $\overrightarrow{B_{1}}$, a magnetização macroscópica é um vetor estático sobre o eixo $z$. (b) Após um pulso de $90^{\circ}$ a componente $x-y$ da magnetização macroscópica se iguala à magnetização inicial, $M_{0}$. (c) Após um tempo menor que $T_{2}$ a coerência de fase dos spins no plano $x-y$ começa a se perder. (d) Após um tempo $T_{2}$ a coerência de fase é perdida e a magnetização resultante no plano $x-y$ se anula. 
onde $\gamma \Delta B_{0}$ corresponde às inomogeneidades de $\overrightarrow{B_{0}}$.

Devido à diferença dos mecanismos de relaxação envolvidos, $T_{1}$ sempre é maior ou igual a $T_{2}$. Na prática, observamos que o tempo necessário para que haja decaimento total do sinal (free induction decay) não é exatamente o valor de $T_{2}$, uma vez que inomogeneidades no campo $\overrightarrow{B_{0}}$ podem influenciar na perda de coerência do sinal. Tanto $T_{1}$ como $T_{2}$ dependem das taxas de mobilidade molecular e das razões giromagnéticas dos núcleos em ressonância e dos núcleos vizinhos que não estão em ressonância.

\subsection{Transformada de Fourier}

Nos espectrômetros de RMN mais comuns, o sinal detectado corresponde às componentes transversais da magnetização macroscópica. Estas componentes possuem valor máximo quando a magnetização se encontra no plano $x-y$, e tendem a retornar exponencialmente ao valor inicial, zero, após a aplicação do pulso. O sinal detectado em NMR é chamado FID - Free Induction Decay, e corresponde à corrente induzida na bobina de recepção devido à magnetização transversal. Durante um experimento de RMN pulsado, são adquiridos dois sinais FID, do decaimento da magnetização no eixo x e do decaimento da magnetização no eixo y, dados por:

$$
\begin{aligned}
& \vec{M}_{x}(t)=\vec{M}_{0} \operatorname{sen}\left[\left(\omega_{0}-\omega\right) t+\Phi\right] e^{\left(-t / T_{2}^{*}\right)} \\
& \vec{M}_{y}(t)=\vec{M}_{0} \cos \left[\left(\omega_{0}-\omega\right) t+\Phi\right] e^{\left(-t / T_{2}^{*}\right)}
\end{aligned}
$$

onde $\Phi$ corresponde à fase em $t=0$ (Figura 2.11). Na prática, observamos que o decaimento das magnetizações transversais apresenta comportamento multi-exponencial, dependendo das inomogeneidades locais em $\overrightarrow{B_{0}}$ nos diferentes spins.

Apesar de o FID conter todas as informações relevantes sobre os spins nucleares, é raro observarmos sua análise direta. O FID pertence ao domínio do tempo, e para análise, o sinal é convertido para o domínio da frequência (espectro) através de uma Transformada de Fourier, dada por:

$$
M(\omega)=\int_{-\infty}^{+\infty} M(t) e^{-i \omega t} d t
$$

em que $M(\omega)$ equivale à magnetização no domínio das frequências, e $M(t)$ é a magnetização em função do tempo após a aplicação do pulso de rf, ou seja, o $M(t)$ é o próprio FID. 


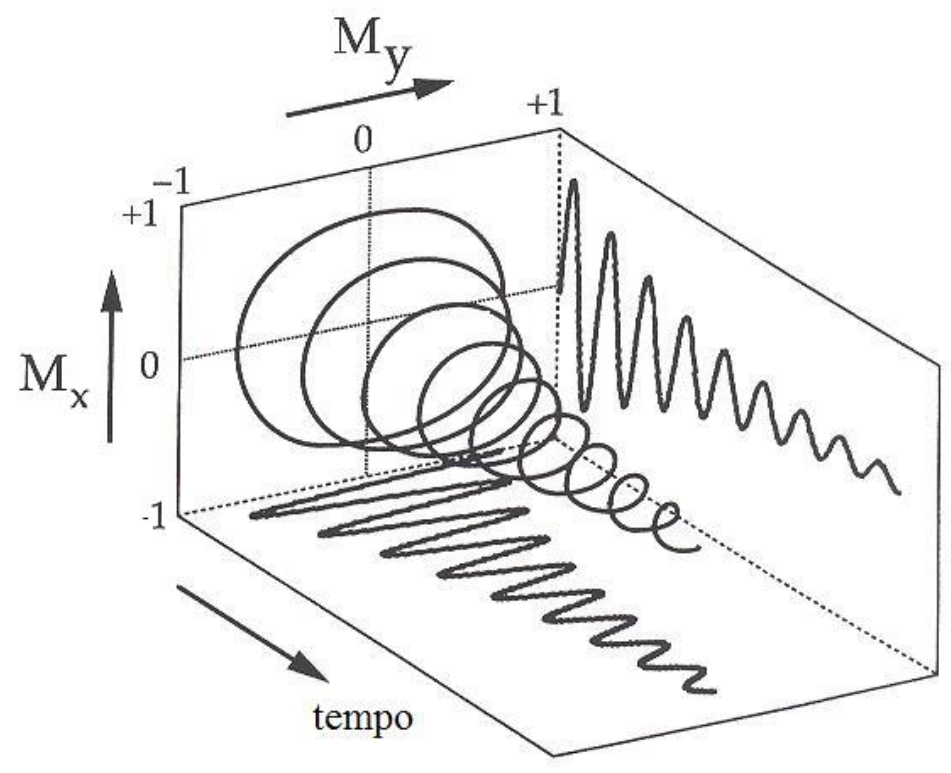

Figura 2.11: Decaimento exponencial das componentes $x$ e $y$ da magnetização transversal [24].

A princípio, é possível construir um espectro a partir de apenas uma das componentes da magnetização transversal, $\vec{M}_{x}(t)$ ou $\vec{M}_{y}(t)$. Neste caso, as frequências negativas não seriam discriminadas, uma vez que $\cos (\omega)=\cos (-\omega)$. Para solucionar este problema, ambas as componentes do FID são medidas, método chamado de detecção em fase e quadratura. A transformada de Fourier utilizada considera estas duas funções ortogonais como entrada, e estas são chamadas de componentes real (fase) e imaginária (quadratura) do FID. Assim, como resultado da transformada, há uma parte real, ou parte absortiva, e outra imaginária ou dispersiva. Certos espectrômetros mais antigos fazem a transformada de Fourier com apenas uma das componentes do sinal. Este tipo de detecção chama-se detecção linear, e para que o sinal transformado desta maneira possa ser analisado metade dos dados encontrados no domínio da frequência são descartados.

Quando realizamos a Transformada de Fourier, o tempo $\mathbf{T}_{2}{ }^{*}$ é inversamente proporcional à largura do sinal de RMN em unidades de frequência. Assim, um núcleo com $\mathbf{T}_{2}{ }^{*}$ longo dá origem a um pico estreito no espectro de RMN em um campo magnético homo- 
gêneo (com bom "shimming"), enquanto um núcleo com $\mathrm{T}_{2}{ }^{*}$ muito curto dá origem a um sinal largo no espectro de RMN mesmo que o espectrômetro esteja bem calibrado (com bom "shimming"').

Os pulsos de rf aplicados têm curta duração (da ordem de dezenas de $\mu \mathrm{s}$ ), uma vez que uma pequena incerteza temporal corresponde a uma grande incerteza de energia, de acordo com o Princípio da Incerteza. Assim, o pulso contém energias variadas, capazes de excitar núcleos com diferentes frequências de ressonância. Quanto mais curto for o pulso, mais frequências serão atingidas. Assim, o FID não é um decaimento exponencial simples, mas sim um interferograma composto por todas as frequências de ressonância do sistema.

\subsection{Espectroscopia de Ressonância Magnética Nuclear}

Em RMN, é possível identificar núcleos atômicos de diferentes espécies, uma vez que a frequência de ressonância de um dado núcleo é proporcional ao valor de sua razão giromagnética, $\gamma$ (Equação 2.7). Adicionalmente, é possível identificar núcleos de uma mesma espécie química em diferentes moléculas ou em diferentes posições de uma mesma molécula. Isto ocorre pois a frequência de ressonância $\omega$ de um dado núcleo (Equação 2.17) não é determinada apenas pelos valores de $\overrightarrow{B_{0}}$ e de $\gamma$, uma vez que o campo magnético ao redor de um determinado núcleo pode ser alterado pelas ligações químicas e pelos núcleos ao redor. Assim, o ambiente químico no qual o núcleo se encontra pode provocar alterações em sua frequência de ressonância. $\mathrm{O}$ efeito do ambiente químico e das ligações químicas na frequência de ressonância dos núcleos é observada em dois fenômenos, o chemical shift ou desvio químico e o acoplamento escalar, acoplamento spin-spin ou acoplamento $J$. Estes dois fenômenos são a base para a espectroscopia por RMN.

\subsubsection{Deslocamento Químico}

O efeito do ambiente químico na frequência de ressonância é chamado de chemical shift ou deslocamento químico. A origem deste fenômeno está na interação de nuvens eletrônicas com o campo magnético externo aplicado $\left(\overrightarrow{B_{0}}\right)$. No caso de átomos isolados, com 
distribuição esférica dos elétrons em torno do núcleo, o campo $B_{0}$ induz uma circulação eletrônica que gera um campo magnético oposto a $B_{0}, B^{\prime}$, dado por

$$
\overrightarrow{B^{\prime}}=-\sigma \overrightarrow{B_{0}}
$$

Assim, o campo ao qual o núcleo é submetido passa a ser dado por:

$$
\vec{B}=\overrightarrow{B^{\prime}}+\overrightarrow{B_{0}}=\overrightarrow{B_{0}}(1-\sigma)
$$

onde $\sigma$ é chamada de proteção magnética. Em átomos isolados, a constante de proteção magnética é dada por:

$$
\sigma=\frac{\mu_{0} e^{2}}{3 m_{e}} \int \rho(r) r d r
$$

em que $e$ é a carga de um elétron, $m_{e}$ a massa de um elétron, $\mu_{0}$ é a permeabilidade magnética no vácuo $\left(\mu_{0}=4 \pi \times 10^{-7} \mathrm{w} / \mathrm{A} \cdot \mathrm{m}\right), \rho(\mathrm{r})$ é a densidade de probabilidade dos elétrons distribuídos no átomo, $\vec{r}$ é o vetor que mede a distância a partir do núcleo e a integração é feita sobre o volume ocupado pelo átomo.

Quando observamos núcleos que fazem parte de moléculas, a mobilidade dos elétrons é restringida. Neste caso, o campo secundário criado não é necessariamente contrário ao campo $B_{0}$ : nas moléculas em que não há elétrons com spins desemparelhados (substâncias diamagnéticas) o campo secundário gerado é orientado contra o campo $B_{0}$, enquanto nas moléculas onde há elétrons com spins desemparelhados (substâncias paramagnéticas ou ferromagnéticas) o campo secundário gerado é orientado a favor do campo $B_{0}$. Isto ocorre pois as substâncias paramagnéticas ou ferromagnéticas possuem um momento magnético permanente que se alinha com o campo magnético externo $\overrightarrow{B_{0}}$. Assim, o campo efetivo ao qual o núcleo nestas substâncias é submetido é a soma do campo $\overrightarrow{B_{0}}$ com o campo intrínseco da substância, de modo que o núcleo sofra a ação de um campo mais intenso que o campo aplicado inicialmente.

A presença de ligações químicas nas moléculas pode fazer com que o campo $\overrightarrow{B^{\prime}}$ gerado tenha direção diferente de $\overrightarrow{B_{0}}$ e intensidades diferentes de acordo com a direção em que $\overrightarrow{B_{0}}$ é aplicado. Assim, a constante $\sigma$ na equação 2.54 é substituída pelo tensor de deslocamento químico, $\tilde{\sigma}$. O tensor deslocamento químico $\tilde{\sigma}$ é constituído por componentes isotrópicas, que não dependem da orientação da molécula em relação ao campo magnético externo, e por componentes anisotrópicas, que por sua vez dependem da orientação da 
molécula em relação ao campo magnético externo. Em amostras sólidas, tanto as componentes isotrópicas como as componentes anisotrópicas de $\tilde{\sigma}$ influenciam nas medidas de RMN, uma vez que no sólido a mobilidade das moléculas é restrita e estas se encontram com uma orientação fixa em relação ao campo magnético $B_{0}$. Em líquidos e gases, a maior mobilidade das moléculas faz com que sua orientação em relação a $B_{0}$ varie continuamente, promediando a zero as componentes anisotrópicas de $\tilde{\sigma}$. Assim, o efeito de deslocamento químico nestas amostras é dado pelo valor médio do tensor, $\sigma$, e a equação 2.54 continua sendo válida. Em espectroscopia de RMN em estado sólido, a técnica de ângulo mágico é utilizada para que se faça uma média das orientações das moléculas em relação ao campo, e então se obtenha medidas próximas do desvio químico médio $\sigma$, desconsiderando-se suas componentes anisotrópicas.

Para cada um dos $i$ átomos presentes em uma molécula, o campo magnético observado será dado pela Equação 2.54. Considerandose que cada átomo se encontre em um ambiente químico diferente, cada um deles apresentará uma constante de proteção magnética diferente, $\sigma_{i}$, e será submetido a um campo magnético resultante diferente, $\vec{B}_{i}$. Uma vez tendo sido alterado o campo magnético, consequentemente se alteram a diferença de energia entre níveis energéticos dos núcleos e a frequência de ressonância. A condição de ressonância passa a ser dada por:

$$
\omega_{i}=\gamma_{i} B_{i z}=\gamma_{i} B_{0}\left(1-\sigma_{i}\right),
$$

considerando-se uma amostra fluida. Assim, cada núcleo apresenta uma frequência de ressonância que varia de acordo com seu ambiente químico:

$$
\omega_{i}=\omega_{0}\left(1-\sigma_{i}\right)
$$

onde $\omega_{0}$ é a frequência básica do espectrômetro para uma determinada espécie química.

$\mathrm{O}$ valor do deslocamento químico varia em função dos diferentes grupos químicos aos quais os núcleos de um mesmo elemento estão ligados. Assim, é possível identificar os componentes químicos de um sistema desconhecido tomando como base certas substâncias adotadas como referência de deslocamentos químicos e calculandose a diferença entre a frequência de ressonância do núcleo em questão e a frequência de ressonância da referência. A frequência de ressonância dos núcleos, de acordo com 2.56, depende do campo externo $B_{0}$ aplicado. Para possibilitar a uniformização das medidas 
realizadas em diferentes campos $B_{0}$, o desvio químico , $\delta$, dificilmente é dado em unidades de frequência, mas sim em ppm, o que torna possível a comparação de medidas realizadas em diferentes campos magnéticos. O cálculo do valor de $\delta$ em ppm é dado por:

$$
\delta=\frac{\left(\nu_{\text {núcleo }}-\nu_{\text {referência }}\right) \cdot 10^{6}}{\nu_{\text {referência }}}
$$

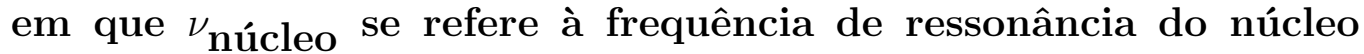

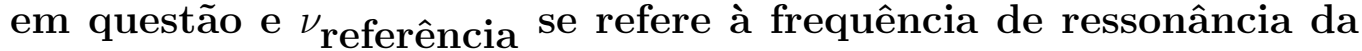
substância adotada como referência de chemical shift.

O composto utilizado como referência deve ser quimicamente inerte e apresentar chemical shift independente de variáveis externas, como temperatura, força iônica, etc, além de apresentar um sinal intenso e bem separado dos demais sinais no espectro de ressonância. Uma substância largamente utilizada como referência de chemical shift é o TMS (tetrametilsilano, figura 2.12-a), cujo deslocamento químico foi referenciado como sendo nulo $(\delta=0)$. Entretanto, o TMS é muito volátil e seu uso é restrito a amostras em solventes orgânicos. Para amostras solúveis em água, frequentemente se utiliza como referência para o chemical shift o TSP (trimetilsilil propionato de sódio, Figura 2.12-b), que também apresenta um único sinal no espectro de RMN em $\delta=0$. Núcleos de diferentes espécies químicas apresentam desvios químicos restritos a diferentes faixas de frequência. Tipicamente, a faixa aproximada de deslocamentos químicos para os átomos de hidrogênio, carbono e fósforo compreende os intervalos de 0 a $10 \mathrm{ppm}, 0$ a $250 \mathrm{ppm}$ e -200 a 120 ppm, respectivamente.
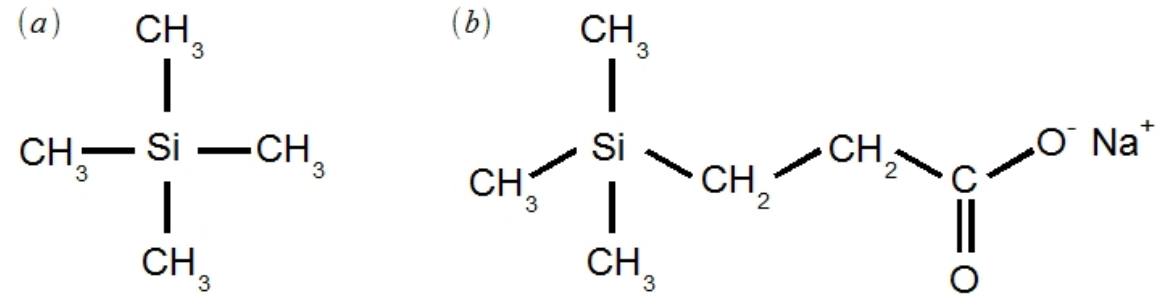

Figura 2.12: Referências de chemical shift. (a)TMS - tetrametilsilano. (b)TSP - trimetilsilil propionato de sódio. 


\subsubsection{Acoplamento spin-spin ou acoplamento J}

Além da frequência de ressonância e da amplitude do sinal, é possível observar o desdobramento (splitting) das linhas de absorção em um espectro de RMN. Este fenômeno ocorre pois a condição de ressonância dos núcleos pode ser alterada devido a interações magnéticas com outros núcleos da amostra. Estas interações podem ocorrer através do espaço (acoplamento dipolar) ou através de ligações químicas (acoplamento escalar). A interação entre dois núcleos A e B de spin $1 / 2, J_{A B}$, é independente do campo $B_{0}$ e pode ser dada pela soma de quatro termos:

$$
J_{A B}=J_{1 A B}+J_{2 A B}+J_{3 A B}+J_{4 A B} .
$$

$J_{1 A B}$ se refere à interação direta dipolo-dipolo, através da qual o campo magnético de um núcleo afeta diretamente outro núcleo, através do espaço. Esta interação é muito intensa, porém tem grande importância apenas para moléculas com pouca mobilidade e com orientação fixa em relação ao campo $B_{0}$, como amostras sólidas. Em amostras líquidas e gasosas, a rápida movimentação das moléculas promedia $J_{1 A B}$ a zero. Os três termos restantes na equação 2.59 têm origem em interações com os elétrons presentes na molécula. $J_{2 A B}$ ocorre pois o momento nuclear do núcleo A interage com as correntes geradas pelos elétrons orbitais submetidos ao campo $B_{0}$, e estes elétrons por sua vez interagem com o momento magnético do núcleo $\mathrm{B}$, e vice-versa. $J_{3 A B}$ tem origem em uma interação de dipolo entre o momento magnético do núcleo $\mathrm{A} \mathrm{e}$ o momento magnético de spin dos elétrons. O dipolo dos elétrons interage com o dipolo magnético do núcleo $\mathrm{B}$ e assim transmite a informação de acoplamento de spin. $J_{4 A B}$ é o termo de contato de Fermi, uma interação entre os momentos magnéticos nucleares e os spins de elétrons nos orbitais $s$. Elétrons em orbitais $s$ têm probabilidade não nula de estar no núcleo, e de transmitir informação do estado de spin nuclear através dos demais elétrons da ligação até atingir outros núcleos. Para o acoplamento próton-próton $\left(J_{H H}\right)$ o termo de contato de Fermi representa cerca de $98 \%$ da magnitude da constante de acoplamento.

Um núcleo isolado com spin igual a $1 / 2$ apresenta apenas dois níveis energéticos, com diferença de energia entre os dois níveis igual a $\Delta E=h \nu$, o que gera uma linha no espectro de RMN na frequência $\nu$. Para um núcleo acoplado a outro de spin $I$, com $2 I+1$ estados de spin, o sinal de RMN observado é um multipleto 
com $2 I+1$ linhas de mesma intensidade separadas pela constante de acoplamento J. Assim, em um sistema com dois núcleos de spin $1 / 2$ acoplados, como por exemplo em uma ligação entre ${ }^{13} \mathrm{C}$ e ${ }^{1} H$, existem quatro estados energéticos possíveis, correspondentes aos quatro estados possíveis de orientação paralela ou antiparalela dos spins nucleares acoplados um em relação ao outro (Figura 2.13).
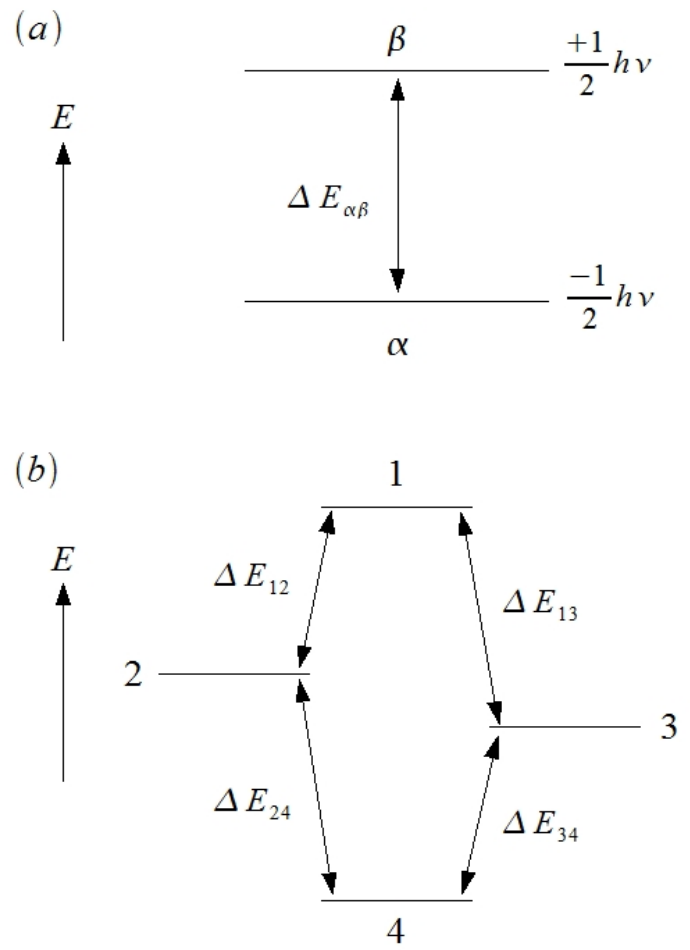

Figura 2.13: Níveis de energia para dois sistemas de spins com núcleos de spin igual a 1/2. (a)Um núcleo magnético isolado apresenta apenas dois níveis de energia, e uma única transição. (b)Dois núcleos acoplados apresentam quatro níveis de energia e quatro transições permitidas.

A constante de acoplamento J, expressa em Hertz $(\mathrm{Hz})$, determina a energia dos estados dos núcleos acoplados. $\mathrm{O}$ valor da constante de acoplamento $\mathrm{J}$ é independente do campo magnético externo $B_{0}$, uma vez que esta se baseia apenas na interação spinspin. Quando $\left|\nu_{A}-\nu_{B}\right|>>J$, observa-se dois dubletos centrados em $\nu_{A}$ e $\nu_{B}$, sendo que a distância entre as linhas dos dubletos vale J. A condição $\left|\nu_{A}-\nu_{B}\right|>>J$ caracteriza os espectros de primeira 
ordem, caso contrário os espectros são chamados de espectros de segunda ordem.

Núcleos que se encontram em um ambiente químico idêntico apresentam mesmo chemical shift e são chamados de núcleos quimicamente equivalentes, enquanto aqueles que experimentam ambiente químico diferente são chamados de núcleos quimicamente não equivalentes e apresentam chemical shift diferentes. Dois núcleos são ditos magneticamente equivalentes quando são quimicamente equivalentes e apresentam mesma constante de acoplamento $\mathrm{J}$ em relação a um terceiro núcleo. $\mathrm{O}$ acoplamento $\mathrm{J}$ não ocorre entre núcleos magneticamente equivalentes. Em espectros de primeira ordem, quando núcleos magneticamente equivalentes estão presentes em um grupo de spins interagentes como o sistema de spins $A X_{n}$, em que há $n$ núcleos magneticamente equivalentes de spin $I$, a linha de absorção do núcleo $A$ no espectro é subdividida em $2 n I+1$ linhas, cada linha correspondendo a uma combinação diferente de spins dos $n$ núcleos acoplados a $A$. A intensidade das linhas geradas assume uma distribuição binomial, e distância entre as linhas é dada pela constante de acoplamento J. Assim, no caso em que há $n=2$ núcleos de spin $1 / 2$ acoplados a $A$, a linha de absorção referente ao núcleo $A$ será subdividida em três, com amplitudes em uma proporção de $1: 2$ : 1 . Quando há mais de dois núcleos magnéticos em uma molécula, o acoplamento ocorre entre cada par, o que gera um padrão de subdivisões sucessivas das linhas de absorção, como observado no espectro da pirimidina (Figura 2.14).

No caso de espectroscopia de ${ }^{1} H$, não se pode observar acoplamento $\mathrm{J}$ entre os dois átomos de hidrogênio diretamente ligados (molécula de hidrogênio) uma vez que eles são magneticamente equivalentes. Pode-se observar acoplamento J entre hidrogênios separados por duas ligações (acoplamento geminal), por três ligações (acoplamento vicinal) ou por mais de três ligações (acoplamento de longo alcance). Quando observamos outros núcleos, como o ${ }^{13} C$, é possível observar o acoplamento através de uma única ligação.

\subsection{O espectrômetro}

O espectrômetro é composto por um magneto, uma fonte de rádiofrequência, uma sonda e um computador. $\mathrm{O}$ magneto produz o campo magnético necessário para os experimentos, em geral está- 


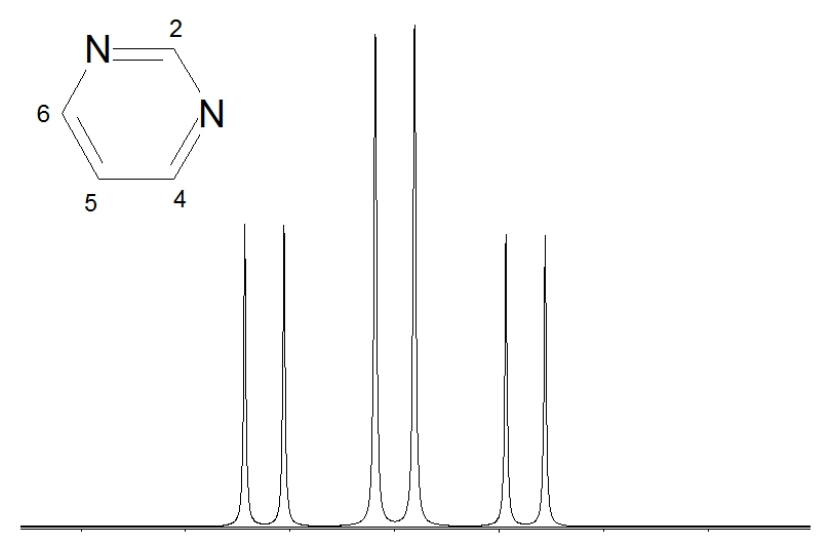

Figura 2.14: Espectro de RMN simulado referente ao próton 5 da pirimidina, mostrando acoplamento com os prótons 4 e 6 (maior valor de constante de acoplamento J) e acoplamento com o próton 2 (menor valor de constante de acoplamento $\mathrm{J}$ ), resultando num tripleto de dubletos.

tico. Existem espectrômetros com magnetos permanentes, eletromagnetos ou magnetos supercondutores, que representam a maioria dos espectrômetros modernos. Um magneto supercondutor é um eletromagneto construído com uma liga metálica que apresenta resistência aproximadamente nula devido ao resfriamento das bobinas por imersão em hélio líquido, a 4,2 K. A bobina e o compartimento com hélio líquido são geralmente envolvidos por um compartimento com nitrogênio líquido $(77,4 \mathrm{~K})$, a fim de se minimizar a troca de calor entre o hélio líquido e o ambiente.

No centro do magneto, na região onde o campo magnético é mais intenso e homogêneo, ficam os sistemas de lock e de shim e o probe, onde se encontram o gerador e o receptor de radiofrequência, além do espaço para a colocação das amostras. O sistema de lock tem o papel de compensar pequenas variações no campo magnético devido a flutuações na temperatura, aproximação de objetos que possam distorcer o campo, etc. O sistema de lock funciona como um segundo espectrômetro, em geral sintonizado na frequência do deutério, que monitora o sinal do deutério e faz pequenas alterações no campo $B_{0}$ para manter sua frequência de ressonân- 
cia constante. O sinal do deutério vem do solvente utilizado na preparação da amostra ou de tubos capilares ou coaxiais contendo solvente deuterado inseridos no tubo porta-amostra. As bobinas de shim têm função de corrigir pequenas distorções no campo $B_{0}$, tornando mais homogêneo o campo magnético na região onde será colocada a amostra.

No probe, além do gerador e do receptor de radiofrequência, encontram-se os circuitos de controle de temperatura, que permitem a realização de experimentos em temperaturas variadas, e o spinner. O spinner é o sistema responsável pela rotação da amostra em torno de seu eixo, o que permite que cada núcleo na amostra experimente um campo magnético médio. Assim, efeitos de inomogeneidade do campo magnético transversal podem ser reduzidos e são observadas linhas mais finas no espectro. A amostra é colocada no interior do probe em tubos porta amostra de vidro, que não apresentam sinal em espectroscopia de RMN. Os experimentos são programados em um computador, onde são configuradas a duração, a largura e a sequência dos pulsos. O computador também recebe o FID (sinal no domínio do tempo) digitalizado e o transforma no espectro (sinal no domínio da frequência) após aplicação da transformada de Fourier.

1

${ }^{1}$ Este capítulo foi escrito com base nas referências [24, 25, 26, 27]. 


\section{Capítulo 3}

\section{A Distrofia Muscular Duchenne}

\subsection{Distrofias Musculares}

Distrofias musculares são um grupo de doenças musculares genéticas caracterizadas por perda progressiva e irreversível de células musculares, o que leva a fraqueza e perda de capacidade motora. A progressão clínica das distrofias musculares apresenta alta variabilidade, ocorrendo desde formas congênitas com progressão rápida e acometimento muscular severo até formas de início tardio e com acometimento muscular brando. Existem pelo menos 30 distrofias musculares diferentes descritas até o momento na literatura [28]. Diversos genes e seus produtos protéicos foram relacionadas com diferentes formas de distrofias. Em geral, as distrofias musculares são causadas por mutações em genes que codificam proteínas musculares sarcolemais, sarcoméricas ou citossólicas, levando a ausência ou perda de função destas proteínas [29].

As distrofias musculares são caracterizadas por repetidos ciclos de degeneração e regeneração muscular com eventual falha na regeneração. Os processos de regeneração muscular são atribuídos a uma população de células presentes no músculo, chamadas células satélite ou células precursoras miogênicas. As células satélites são células mononucleadas que se encontram na periferia das fibras musculares adultas em estado quiescente, mas que na presença de estímulos, como injúria ou maior demanda de atividade muscular, tornam-se ativas e podem fundir-se entre si e formar novas fibras musculares (hiperplasia) ou fundir-se às fibras musculares já existentes (hipertrofia) [30]. Acredita-se que nas distrofias musculares observe-se exaustão das células satélites, o que provocaria as fa- 
lhas na regeneração do tecido muscular lesado. Histologicamente, o músculo distrófico apresenta variação no tamanho das fibras, infiltração por tecido adiposo e conjuntivo e focos de necrose [29].

\subsection{Distrofia Muscular Duchenne}

Entre todas as distrofias musculares, a mais comum é a distrofia muscular Duchenne (DMD), que afeta aproximadamente $1 \mathrm{em}$ cada 3000 recém-nascidos vivos do sexo masculino [31]. A DMD é uma doença recessiva ligada ao $\mathrm{X}$, e foi inicialmente descrita no século XIX $[32,33]$. Os recém-nascidos não apresentam nenhum sinal da doença, e os primeiros sintomas surgem na primeira infância, quando a criança apresenta falta de equilíbrio, quedas frequentes, dificuldades para correr, subir escadas e pular, e hipertrofia da panturrilha, seguidos por fraqueza progressiva principalmente da musculatura proximal. Além do comprometimento da musculatura, cerca de $30 \%$ dos pacientes com DMD apresentam comprometimento do sistema nervoso central com gravidade variável $[34,35]$. Devido à degeneração muscular progressiva, por volta dos dez anos de idade os pacientes perdem a capacidade de deambular, iniciando o uso de cadeiras de rodas. Os pacientes com DMD raramente sobrevivem após os trinta anos, quando complicações cardio-respiratórias são as principais causas de morte [29].

A DMD é causada por mutações no gene que codifica a proteína distrofina, no locus Xp21 [29]. Nos pacientes com DMD, observa-se a ausência de distrofina ou expressão da proteína truncada em conformação não funcional. [36, 37].Mutações no mesmo gene podem levar a uma forma mais benigna de distrofia, a distrofia muscular Becker (DMB), em que a distrofina é observada em menor quantidade ou em conformação pouco funcional. Os pacientes com DMB apresentam fenótipo bastante variável, mas em geral começam a apresentar sintomas por volta dos doze anos, com acometimento muscular semelhante ao observado na DMD, porém com progressão mais lenta. Os pacientes com DMB em geral vão a óbito entre quarenta e cinquenta anos de idade [29].

Os pacientes com DMD apresentam elevado nível de enzimas específicas de células musculares no sangue, como a creatina quinase. Esta elevada concentração de proteínas musculares no soro sanguíneo sinaliza lesão das células musculares com extravasamento de seu conteúdo citoplasmático. A análise histológica mostra padrões 
de músculo distrófico, com focos de necrose e inflamação, invasão do tecido por macrófagos, variação no tamanho das fibras musculares, fibras fendidas e fibras centronucleadas e substituição por tecido conjuntivo e adiposo (Figura 3.1). Tanto os níveis elevados de creatina quinase no soro como os achados histológicos característicos de músculo distrófico podem ser observados antes mesmo do surgimento dos primeiros sintomas e em alguns casos de mulheres portadoras da mutação. Uma vez que os músculos esqueléticos desempenham papel importante no equilíbrio da glicemia atuando como reservatório de substratos para a gliconeogênese, a degeneração muscular observada nos pacientes com DMD desencadeia diversas alterações metabólicas. Os pacientes com DMD apresentam redução na concentração de glicose e aumento na concentração de corpos cetônicos e ácidos graxos livres no soro com o avanço da doença, além de alterações nas concentrações de hormônios associados ao metabolismo energético, como insulina e glucagon [38].
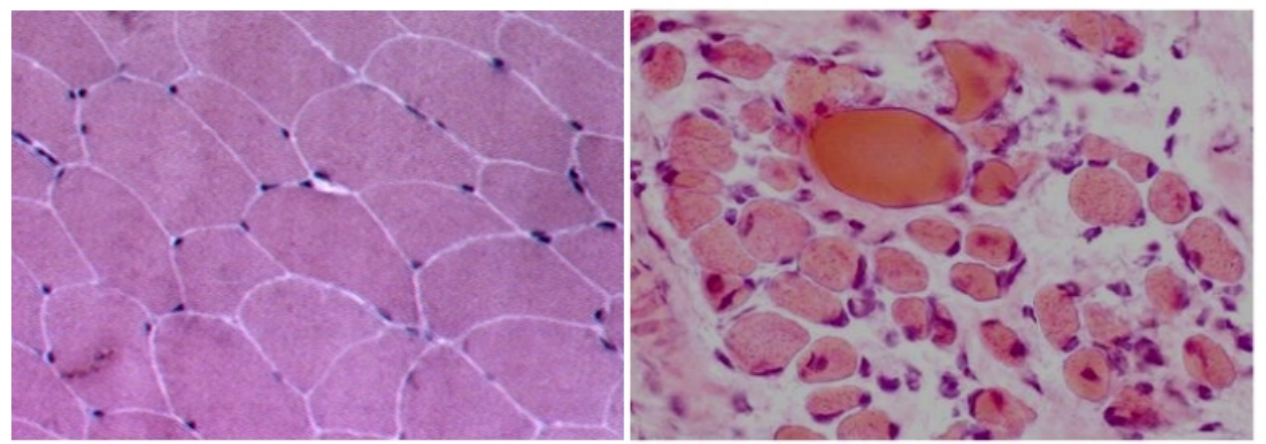

Figura 3.1: Aspecto histopatológico do músculo distrófico de paciente com DMD (à esquerda), comparado com músculo normal (à direita). Aumento de 400 vezes.

O diagnóstico das distrofias musculares se inicia com uma avaliação clinica e neurológica, além de dosagem da creatina-quinase no soro sanguíneo. Quando há suspeita de uma distrofia cujo gene já está bem caracterizado, inicia-se o estudo pela triagem de mutações neste gene. A identificação da mutação confirma o diagnóstico do paciente afetado e permite o aconselhamento genético da família. Quando o diagnóstico molecular não é informativo, a análise histológica de biópsias musculares mostra-se necessária para o correto diagnóstico das distrofias musculares.

Não existe cura para as distrofias musculares até o momento. 
Corticóides podem ser utilizados na tentativa de reduzir a velocidade de progressão da doença, e cuidados especiais no controle de dificuldades respiratórias podem prolongar o tempo de vida dos pacientes. Diferentes abordagens têm sido estudadas para o desenvolvimento de terapias para as distrofias musculares, em especial para a DMD, como a terapia gênica e a terapia celular [39, 40]. Para tais estudos, tem se mostrado cada vez mais importante o estabelecimento de uma metodologia de avaliação dos benefícios da terapia de maneira não invasiva, uma vez que o acompanhamento de benefícios de terapias em geral é feito através de biópsias musculares.

\subsection{O Complexo Distrofina-Glicoproteínas}

A distrofina é uma proteína de $427 \mathrm{kDa}$ presente no citoesqueleto de células musculares esqueléticas e cardíacas, além de células nervosas $[35,41,36]$. Nas fibras musculares, a distrofina é encontrada na face interna da membrana celular, associada a um complexo de proteínas e glicoproteínas transmembrana, o Complexo Distrofina-Glicoproteínas (DGC - Dystrophin-Glicoprotein Complex). O DCG é formado pelos subcomplexos sarcoglicano ( $\alpha$ e $\beta$-SG) e distroglicano ( $\alpha, \beta, \gamma$ e $\delta$-DG), além de distrofina, sintrofinas, distrobrevinas, sarcospan e actina [42]. Acredita-se que a distrofina seja organizada como um dímero anti-paralelo, com um sítio de ligação para a actina no domínio N-terminal e sítios de ligação para proteínas de membrana do DGC em seu domínio C-terminal. A distrofina liga-se ao DGC através da glicoproteína $\beta$-DG, que se encontra ligada às sarcoglicanas e à $\alpha$-DG. As sarcoglicanas são glicoproteínas integrais de membrana altamente associadas, enquanto a $\alpha$-DG possui um sítio de ligação à laminina-2, proteína da matriz extracelular. Assim, o DGC faz a ligação entre o citoesqueleto sarcolemal e a matriz extracelular (Figura 3.2) $[43,44,45,46,47,48,49]$.

O DGC é essencial para a manutenção da estabilidade da fibra muscular e do sarcolema. Sugere-se que o DGC estabilize o sarcolema e proteja as fibras musculares dos danos induzidos pelo estresse mecânico da contração muscular [28]. Além de função mecânica e estrutural, acredita-se que o DGC tenha outras funções, interferindo na agregação e funcionamento de canais iônicos e de receptores para neurotransmissores no sarcolema [50, 51]. A dis- 


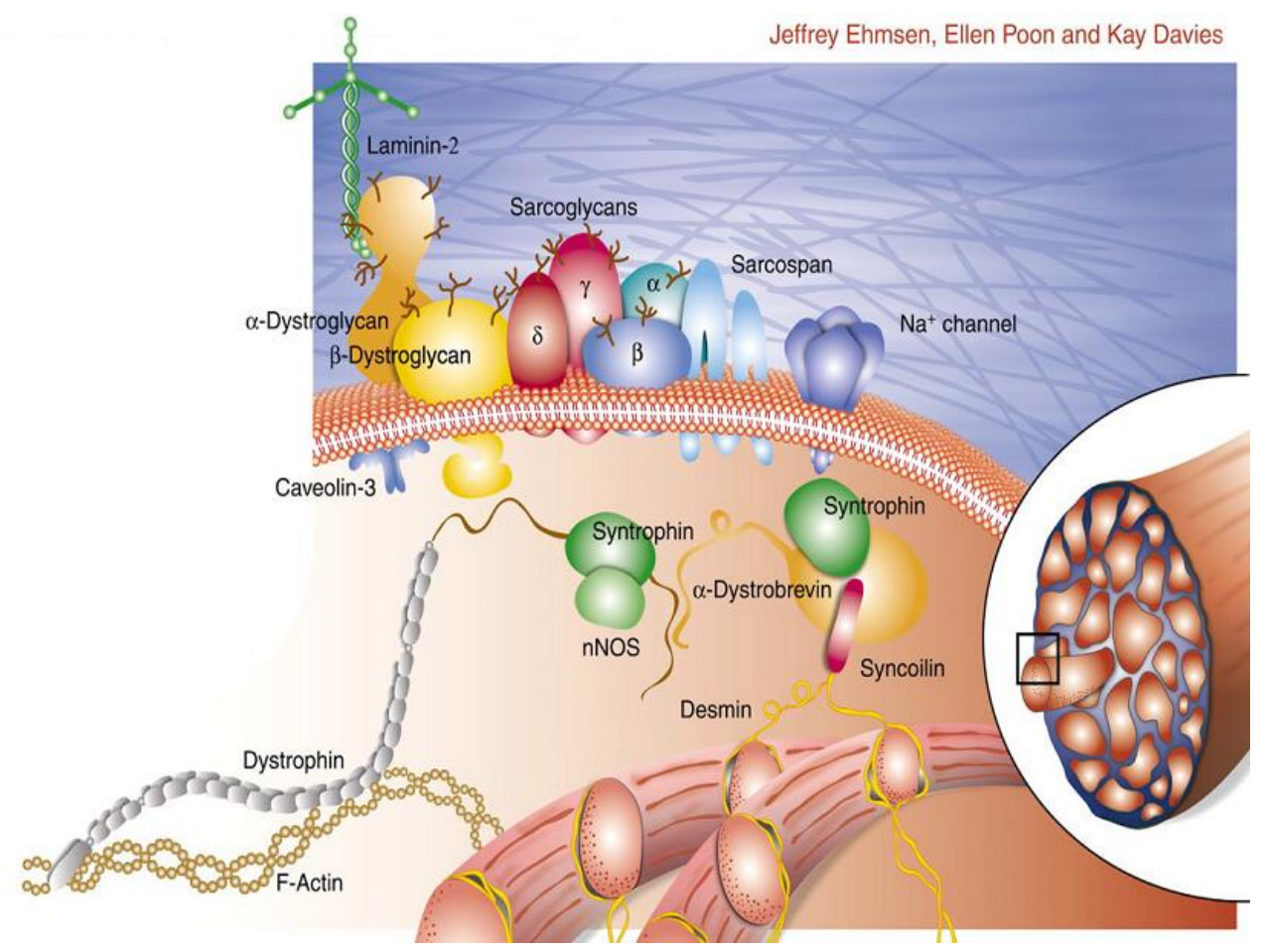

Figura 3.2: Representação gráfica do Complexo Distrofina-Glicoproteínas.

trofina apresenta especial envolvimento na regulação dos canais de $\mathrm{Ca}^{2+}$ da membrana celular $[36,52]$. A ausência da distrofina ou de outros componentes do DGC leva a diferentes formas de distrofias. Na DMD, a ausência da distrofina provoca uma redução secundária nos demais componentes do DGC, e inicia uma cascata de degeneração muscular. Progressivamente as células musculares morrem e são substituídas por tecido adiposo ou tecido conjuntivo. Acredita-se que a ausência de distrofina ou a instabilidade do DGC torne as fibras musculares mais sensível ao estresse mecânico proveniente da atividade muscular, o que levaria à morte celular e degeneração muscular observada nos pacientes. A injúria provocada por esforço muscular é considerada uma propriedade normal de células musculares esqueléticas, e estaria relacionada com a resposta adaptativa do músculo à atividade física [53]. Nos pacientes com DMD, acredita-se que o limiar de tolerância a este estresse mecânico esteja reduzido. Com os repetidos ciclos de degeneração e regeneração as células satélites se esgotariam e o tecido muscular teria sua capacidade de regenerar-se reduzida, o que justificaria a 
substituição por tecido conjuntivo e adiposo.

\subsection{O camundongo $m d x$, modelo animal para a DMD}

O camundongo $m d x$ (X-linked muscular dystrophy) é o modelo animal mais comum para a DMD [54]. A linhagem $m d x$ é isogênica e foi selecionada a partir de uma mutação espontânea observada em camundongos saudáveis da linhagem C57Black/10ScSn. Os camundongos $\boldsymbol{m d x}$ foram identificados por apresentarem elevados índices de creatina quinase e piruvato quinase no sangue, além de apresentarem características de músculos distróficos em análise histológica [55]. Os camundongos $m d x$ apresentam mutação no gene da distrofina, no éxon 23, que provoca a ausência desta proteína em suas células [56]. A ausência da distrofina leva a uma redução secundária das proteínas associadas à distrofina, assim como nos pacientes com DMD [57]. Os camundongos $m d x$, entretanto, apresentam uma distrofia muito mais branda que a encontrada em humanos, são viáveis, se reproduzem e têm expectativa de vida próxima à de um camundongo saudável [55].

Os diferentes grupos musculares dos camundongos $m \boldsymbol{d x}$ apresentam comprometimento em graus variados, sendo que em geral os músculos rápidos são mais afetados por lesões induzidas por estresse mecânico $[58,59]$. Entre os músculos esqueléticos, o mais afetado é o diafragma, que apresenta o padrão de degeneração, necrose e substituição por tecido conjuntivo observado nos músculos dos membros de pacientes com DMD. Em torno de 1 ano e meio de idade, os músculos acessórios da respiração dos camundongos $\boldsymbol{m d x}$ passam a apresentar as mesmas características observadas no diafragma aos 6 meses de idade. A atividade respiratória por unidade de massa é proporcional à massa do animal elevada a $-0,22$ [60]. Assim, quanto menor a massa do animal em questão maior a atividade muscular envolvida na respiração. Uma vez que a ausência de distrofina leva a uma menor resistência das fibras musculares ao estresse mecânico causado pela atividade física, o diafragma seria um músculo mais sensível à ausência desta proteína em animais de pequeno porte devido à sua maior atividade quando comparados a animais de maior massa [60]. O diafragma ainda mostra comprometimento variado de acordo com a região analisada: a região 
crural apresenta-se mais severamente afetada pela distrofia que a região costal [61].

Além do diafragma, músculos dos membros posteriores dos camundongos $m d x$, como o gastrocnêmio, são largamente estudados. Nos camundongos $\boldsymbol{m d x}$, o grupo muscular gastrocnêmio apresenta poucos focos de degeneração-regeneração em análise histológica nas primeiras duas semanas de vida. O número de focos de degeneração-regeneração aumenta progressivamente, atingindo um pico em cerca dois a três meses de idade, quando há numerosos focos de necrose envolvendo número variado de fibras. Entre três e seis meses de idade o processo necrótico diminui progressivamente, com focos necróticos contendo uma ou poucas fibras, além de haver muitas fibras centronucleadas. Após os seis meses de idade, há progressiva variação no calibre das fibras e deposição de fibrilas de colágeno nos gastrocnêmios de camundongos $m d x[62,63]$. Outros músculos dos membros posteriores, como o tibial anterior, o extensor digital longo e o plantar apresentam um padrão semelhante de degeneração-regeneração muscular, porém com início ligeiramente mais tardio [63]. Já os músculos envolvidos na mastigação, como o masseter, são mais brandamente acometidos [64].

Acredita-se que uma redução no processo de necrose seja uma das causas do fenótipo mais brando observado nos camundongos $m d x$ em comparação com os pacientes com DMD [62, 65]. Além disso, o fenótipo mais brando observado nos camundongos $m \boldsymbol{d x}$ tem sido atribuído a uma maior capacidade de regeneração muscular destes animais. Esta hipótese pode ser fundamentada na observação de camundongos $\boldsymbol{m d x}$ irradiados com baixas doses de radiação gama, o que bloqueia os processos de regeneração. Os animais irradiados apresentam lesões musculares semelhantes às observadas em pacientes com DMD em estágio avançado da doença [66, 67]. Há ainda trabalhos na literatura mostrando que após um ciclo de degeneração-regeneração as fibras musculares se tornariam mais resistentes à necrose, e tal fato foi atribuído a uma maior resistência das fibras de menor calibre ao estresse mecânico causado pela contração muscular [68, 69]. 


\subsection{A espectroscopia por RMN no estudo das distrofias musculares com ausência de dis- trofina}

Há diversos trabalhos na literatura em que são estudadas características metabólicas e morfofuncionais em distrofias através de espectroscopia e imageamento por ressonância magnética nuclear (RMN), mas até o momento não existe um protocolo definido para uso clínico $[11,5,14,70,22]$. A RMN é uma técnica promissora por ser não invasiva e segura para uso em medicina, uma vez que não envolve uso de radiação ionizante. Diferentes técnicas de RMN permitem a obtenção de imagens de tecidos moles com alta qualidade e possibilitam a análise metabólica através da espectroscopia.

Espectroscopia por RMN in vivo de fósforo-31 $\left({ }^{31} \mathrm{P}\right)$ tem sido largamente utilizada no estudo do metabolismo muscular energético em diferentes doenças neuromusculares [71, 72]. A espectroscopia por $\mathrm{RMN}$ de ${ }^{31} \mathrm{P}$ tem destaque na análise de fosfatos de alta energia (fosfocreatina, ADP, ATP e proporção de fosfato inorgânico) e de pH. Em pacientes com DMD e DMB, observa-se elevado pH intracelular e elevada razão fósforo inorgânico / fosfocreatina em repouso, o que indica deficiência no metabolismo energético $[19,20]$. Há diversos trabalhos na literatura envolvendo análise metabólica de camundongos $m d x$, tanto in vivo como in vitro, através da espectroscopia por RMN de ${ }^{31} \mathbf{P}$ em diferentes estágios de evolução da doença e do músculo sadio, em condição de repouso e de atividade física intensa $[15,16,17,18]$.

Através da espectroscopia por RMN de hidrogênio $\left({ }^{1} \mathbf{H}\right)$ é possível a identificação e a quantificação de metabólitos de diferentes vias bioquímicas, como glicose, creatina, lipídeos, lactato, acetato, entre outros. Sharma e colaboradores [14] aplicaram a espectroscopia de ${ }^{1} \mathbf{H}$ NMR uni e bi-dimensional ao estudo de extratos de biópsias musculares de pacientes com DMD e observaram alterações nas concentrações de diversos metabólitos em comparação com controles. Foi observada redução nas concentrações de glicose, lactato e aminoácidos gliconeogênicos, como glutamina e alanina. A redução na glicose foi associada à redução na concentração dos substratos para a gliconeogênese (alanina, glutamina) e a anomalias na membrana dos músculos dos pacientes com DMD. Foi observada redução nos níveis de lactato, possivelmente devido a uma menor atividade glicolítica anaeróbica nos pacientes. Esta preferência pelo 
metabolismo oxidativo para a geração de energia nos pacientes com DMD também justificaria a observação de $\alpha$-cetoglutarato, um intermediário do ciclo de Krebs, apenas nos pacientes com DMD. Também foi observada redução nas concentrações de acetato e carnitina, resultados relacionados uma vez que a carnitina é necessária para o transporte de ácidos graxos para o interior da mitocôndria, onde ocorre a $\beta$-oxidação e formação de acetato e propionato. Por fim, foi observada redução nas concentrações de glicerofosforilcolina, fosforilcolina e colina nos pacientes com DMD, o que provocaria uma sequência de alterações que acarretam em modificações na composição dos fosfolipídeos da membrana celular. Tais anomalias na membrana contribuiriam para a doença, uma vez que os fosfolipídeos da membrana têm função estrutural e contribuem na regulação da atividade de enzimas ligadas à membrana.

Griffin e colaboradores realizaram experimentos in vitro em fragmentos de tecido cardíaco de camundongos $m d x$ através de espectroscopia por RMN de ${ }^{1} \mathrm{H}$ em estado sólido em uma e duas dimensões [73], além de análise metabólica de tecidos musculares de camundongos $m d x$, incluindo diafragma e coração [10]. Nestes estudos, foram observados padrões metabólicos distintos em tecido cardíaco, músculos esqueléticos e no cerebelo e córtex cerebral. Foram identificados diversos metabólitos capazes de diferenciar tecidos distróficos e de controle, provenientes de diferentes vias metabólicas, como glicólise, $\beta$-oxidação, metabolismo de lipídeos, osmorregulação e outros. Tais vias metabólicas provavelmente são alteradas pelo rompimento da membrana celular e pelas alterações no influxo de $\mathrm{Ca}^{2+}$, que alteram a osmorregulação e homeostase. Rae e colaboradores [74] observaram elevação na concentração de compostos contendo colina em espectroscopia por $\mathrm{RMN}$ de ${ }^{1} \mathrm{H}$ in vivo do cérebro de pacientes com DMD em comparação com controles. Alterações nas concentrações de compostos contendo colina foram observadas em diversas outras patologias, além de serem observadas em experimentos envolvendo eletroporação de células, o que sugere que o acompanhamento de variações nas concentrações de compostos contendo colina pode permitir o monitoramento de alterações na estabilidade da membrana celular [75]. Griffin e colaboradores [76] ainda observaram através de espectroscopia por RMN de ${ }^{1} \mathrm{H}$ in vitro padrões metabólicos distintos em diafragma e coração de camundongos $\boldsymbol{m d x}$ com expressão variada de utrofina, e em amostras de diafragma de camundongos $m d x$ e de controle com diferentes idades. Neste caso, observou-se redução na concentração 
de creatina e aumento na concentração de taurina com a evolução da doença.

McIntosh e colaboradores [12] observaram diferenças entre músculo sadio e distrófico de diferentes idades além de diferenças em músculos distróficos após tratamento com glicocorticóides através de espectroscopia de ${ }^{1} \mathrm{H}$ RMN ex vivo. Foram observados níveis mais baixos de creatina e de taurina nos camundongos $m \boldsymbol{d x}$ na chamadas fases pré-distrófica (menos de 3 semanas) e distrófica ( 3 a 6 semanas). Os níveis de taurina aumentaram com a estabilização da doença e apresentaram correlação com o número de fibras centronucleadas, característica de regeneração muscular. O diafragma apresentou elevados níveis de lipídeos quando comparado aos músculos dos membros. Após tratamento com glicocorticóides, observou-se elevação nos níveis de taurina e creatina, especialmente nos músculos dos membros. A taurina e a creatina foram identificadas como marcadores consistentes para o processo de regeneração muscular nos camundongos $m d x$, enquanto a taurina foi considerada um bom marcador para a resposta ao tratamento com glicocorticóides, o que permitiu relacionar a taurina a uma maior estabilidade da membrana celular e regeneração das células musculares, como observado em morfometria. O método foi capaz de diferenciar mesmo animais controles de camundongos $\boldsymbol{m d x}$ com menos de três semanas de idade, fase em que dificilmente os tecidos são identificados por histologia. Em outro trabalho, McIntosh e colaboradores mostraram que há correlação entre os níveis de taurina observados em espectroscopia por $\mathrm{RMN}$ de ${ }^{1} \mathrm{H}$ in vitro e ex vivo e a extensão de tecido regenerado em músculo esquelético [13]. A taurina apresenta diversas funções metabólicas, estando envolvida na regeneração muscular, na estabilização de membranas celulares, na homeostase do $\mathrm{Ca}^{2+}$, além de atuar como neurotransmissor [77].

Radda e colaboradores [35] e Tracey e colaboradores [78], entre outros, utilizaram a espectroscopia de $\mathrm{RMN}$ de ${ }^{1} \mathrm{H}$ in vitro e in vivo no estudo do sistema nervoso central de camundongos $m \boldsymbol{d x}$. Cole e colaboradores [79] observaram alterações em espectroscopia por RMN de ${ }^{31} \mathrm{P}$ e ${ }^{1} \mathrm{H}$ compatíveis com anomalias no controle da concentrações iônicas dentro e fora das células musculares de camundongos $m d x$ e em camundongos duplos mutantes com ausência de distrofina e utrofina.

Misra e colaboradores observaram diferenças no valor de $\mathbf{T}_{1}$ entre os músculos de galinhas distróficas e de controle [80]. Walter e colaboradores [23] avaliaram através de imageamento e espectros- 
copia por RMN o tecido muscular de camundongos $\boldsymbol{m d x}$, controles e nockout para $\gamma$-sarcoglicana ( $\gamma$ sg-/-) com e sem terapia gênica. Os autores observaram variações nos tempos de relaxação transversal $\left(\mathrm{T}_{2}\right)$ compatíveis com o nível de degeneração muscular e não relacionadas com o grau de infiltração por tecido adiposo, permitindo uma avaliação não invasiva do grau de inflamação e necrose do tecido, além de observarem melhorias nos músculos tratados com terapia gênica através de imagens com contraste. Há ainda diversos outros trabalhos envolvendo rastreamento de células tronco através de RMN $[81,82]$ e o acompanhamento in vivo da expressão de gene reporters [83].

Considerando a viabilidade da aplicação de métodos espectroscópicos de RMN no estudo de distrofias musculares, este trabalho visa o estabelecimento de uma metodologia padrão para o uso de espectroscopia de $\mathrm{RMN}$ de ${ }^{1} \mathrm{H}$ na avaliação do estágio da doença e de benefícios de possíveis terapias em camundongos $m d x$. 


\section{Capítulo 4}

\section{Procedimentos Experimentais}

\subsection{Animais}

Os animais utilizados foram cedidos pelo biotério de criação e manutenção do Departamento de Patologia da Faculdade de Medicina Veterinária e Zootecnia da USP, em parceria com o Centro de Estudos do Genoma Humano - Instituto de Biociências da USP. Foram utilizados camundongos C57Black-mdx ( $m d x)$ e C57Blackselvagem $(\mathrm{Ctrl})$. Os animais foram mantidos em ambiente controlado, com sistema de ar condicionado central para ventilação e exaustão, iluminação controlada 12 horas claro/12 horas escuro, temperatura mantida em $22^{\circ} \mathrm{C}$, com ração e água à vontade.

Ao todo foram eutanasiados 45 animais em câmara de $\mathrm{CO}_{2}$, sendo 12 camundongos $\boldsymbol{m d x}$ com 3 meses de idade, 11 camundongos Ctrl com 3 meses de idade, 12 camundongos $\boldsymbol{m d x}$ com 6 meses de idade e 10 camundongos $C$ trl com 6 meses de idade. O estudo recebeu autorização do Comitê de Ética em Experimentação Animal do Instituto de Ciências Biomédicas da Universidade de São Paulo.

\subsection{Preparação das Amostras}

Foram coletados os músculos quadríceps femural e diafragma dos animais após eutanásia. Foram coletados os quadríceps bilaterais, sendo que para cada animal um dos quadríceps foi utilizado para o estudo de espectroscopia por RMN e o músculo contralateral foi armazenado para análise histológica. Os diafragmas coletados foram divididos sagitalmente em duas partes, de modo que cada uma delas contivesse tanto parte do diafragma costal como parte 
do diafragma crural. Uma das partes foi reservada para o estudo de espectroscopia por RMN e a outra foi reservada para análise histológica. Os tecidos próprios para ERMN foram congelados em $\mathbf{N}_{2}$ líquido e mantidos a $-70^{\circ} \mathrm{C}$ até sua utilização. Os tecidos próprios para análise histológica foram crioprotegidos com talco, fixados em bloco de cortiça e congelados em $\mathrm{N}_{2}$ líquido. $\mathrm{O}$ material para análise histológica foi mantido em $\mathrm{N}_{2}$ líquido até a sua utilização.

Para a preparação das amostras para espectroscopia por RMN de quadríceps femural, cada músculo foi triturado em $2 \mathrm{ml}$ de solução de água destilada e acetonitrila 1:1, com o uso de um mixer Polytron PT1200. Durante este processo as amostras foram mantidas imersas em gelo. Após homogeneização, as amostras foram centrifugadas em centrífuga refrigerada a $4^{\circ} \mathrm{C}$ a $13200 \mathrm{rpm}$, por ao menos 40 minutos. O sobrenadante foi então liofilizado, por aproximadamente 24 horas, no Laboratório de Liofilização do Instituto de Farmácia e Bioquímica da USP. Após a liofilização, o pó obtido foi pesado e ressuspendido em $0,7 \mathrm{ml}$ de solução de TSP (trimetilsilil propionato de sódio - Sigma) e $\mathrm{D}_{2} \mathrm{O}$ (Sigma) a $10 \mathrm{mM}$. As amostras foram mantidas $\mathrm{a}-70^{\circ} \mathrm{C}$ até a realização dos experimentos de espectroscopia por RMN.

O procedimento de preparação das amostras de diafragma para espectroscopia por RMN foi semelhante. O tecido, em muito menor quantidade quando comparado ao músculo quadríceps femural, foi triturado em apenas $1 \mathrm{ml}$ de solução de água destilada e acetonitrila 1:1, com auxílio de um mixer Polytron PT1200. Depois de homogeneizadas, as amostras foram centrifugadas em centrífuga refrigerada a $4^{\circ} \mathrm{C}$, a $13200 \mathrm{rpm}$, por 160 minutos, com o objetivo de se obter amostras menos turvas que as amostras de quadríceps, o que resultaria em melhores resultados para as medidas de espectroscopia por RMN. O sobrenadante foi então liofilizado e em seguida o pó obtido foi pesado e ressuspendido em solução de TSP e $\mathrm{D}_{2} \mathrm{O}$ a $10 \mathrm{mM}$.

\subsection{Metodologias de Espectroscopia por RMN}

\subsubsection{Medidas de tempo de relaxação longitudinal T1 (spin-rede)}

Uma das formas de se obter espectros de RMN com alta razão sinal-ruído é realizar sucessivas aquisições de sinal e calcular a mé- 
dia das mesmas para gerar o FID. Neste caso, é preciso evitar a condição de saturação da magnetização entre as sucessivas aquisições de sinal. No experimento de RMN, depois de algumas medidas aplicando-se um pulso de $\mathrm{RF}$ de $90^{\circ}$ a magnetização ao longo do eixo $z, M_{z}$, evolui de acordo com a Equação 2.47. A fim de se garantir que a magnetização no eixo $z$ sempre partirá do seu estado de equilíbrio durante o processo cumulativo de medida, é ajustado na sequência de pulso utilizada no experimento de RMN um valor de tempo de repetição (TR) entre a 3 e 5 vezes o valor de $T_{1}$. Para a determinação experimental do valor de $T_{1}$ podem ser utilizadas diferentes sequências de pulso, sendo que neste trabalho foi utilizado o método de inversão-recuperação.

O método de inversão-recuperação consiste na aplicação de um pulso de $180^{\circ}$ que posiciona a magnetização na direção de $-z$ (inversão da magnetização) seguido de um intervalo de tempo variável em que a magnetização tende a voltar à condição inicial, de acordo com a Equação 2.48. Após o intervalo de recuperação $\tau$, um pulso de $90^{\circ}$ é aplicado, posicionando a magnetização no plano transversal e permitindo a obtenção do FID. Quando o tempo de recuperação for zero, a magnetização que se encontrava em $-z$ é excitada e se orienta paralela a $-y$. Nesta condição, observa-se uma linha invertida no espectro de RMN com intensidade negativa máxima. Quando o tempo de recuperação for da ordem de 3 a 5 vezes $T_{1}$, a magnetização terá retornado à posição inicial, na direção de $+z$, e após o pulso de $90^{\circ}$ se posicionará na direção de $+y$, dando origem a uma linha de intensidade positiva máxima no espectro de RMN. Com um gráfico da amplitude da linha de ressonância em função do tempo $\tau$, pode-se ajustar a curva à equação 2.48 e obter o valor de $T_{1}$. Alternativamente, pode-se calcular o valor de $T_{1}$ obtendo-se o tempo exato em que a intensidade do pico de ressonância vale zero, $t_{0}$, e calcular o valor de $T_{1}$ a partir da equação

$$
T_{1}=\frac{t_{0}}{\ln 2}
$$

Para a determinação do tempo de espera a ser utilizado nas sequências de pulsos, foi realizado um experimento de medida de $\mathrm{T}_{1}$ em uma das amostras ( $M d x 36$-diafragma) com o método de inversão-recuperação. A sequência consistia na aplicação de um pulso de $180^{\circ}$ (inversão) seguido por um tempo de recuperação variável e por um pulso de $90^{\circ}$ (Figura 4.1). Foi selecionado o metabólito com maior $\mathrm{T}_{1}$ (taurina, Tabela 4.1) e o valor do tempo 
de espera utilizado nas medidas foi definido como 10 segundos, aproximadamente 3 vezes o valor do maior $T_{1}$. A Figura 4.2 mostra as intensidades dos sinais obtidas nos diferentes valores de tempo de recuperação para os picos de taurina, creatina e lactato.

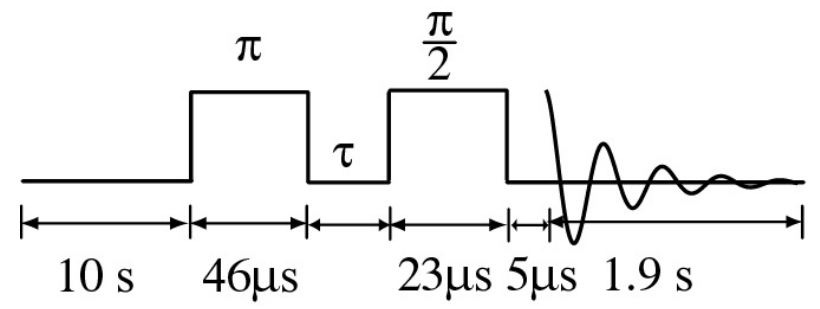

Figura 4.1: Sequência de pulsos utilizada no experimento de inversão-recuperação para determinação do T1.

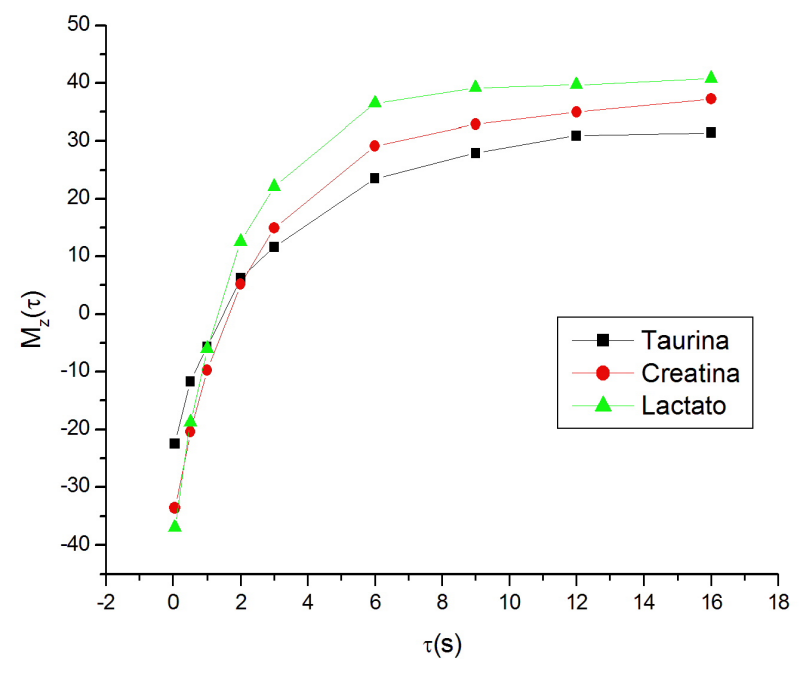

Figura 4.2: Intensidades dos picos de creatina, taurina e lactato em função do tempo de recuperação $\tau$.

\subsubsection{Espectroscopia de alta resolução de ${ }^{1} H$}

As medidas de espectroscopia por RMN de ${ }^{1} H$ foram realizadas à temperatura ambiente (aproximadamente $22^{\circ} \mathrm{C}$ ), em tubos porta- 


\begin{tabular}{|c|c|c|}
\hline Metabólito & Frequência $(\mathrm{ppm})$ & $\mathrm{T} 1 \pm$ Incerteza \\
\hline Creatina & 3,03 & $2,44 \pm 0,09$ \\
\hline Taurina & 3,42 & $2,82 \pm 0,19$ \\
\hline Lactato & 1,30 & $1,94 \pm 0,06$ \\
\hline
\end{tabular}

Tabela 4.1: Valores de T1 observados para cada um dos picos selecionados.

amostra de vidro de $5 \mathrm{~mm}$ de diâmetro externo, em um espectrômetro Varian de $200 \mathrm{MHz}$.

As amostras de quadríceps femural foram submetidas a uma sequência de pulso que consistia num pulso simples de aproximadamente $45^{\circ}$, com tempo de repetição ou espera (d1) de $10 \mathrm{~s}$, duração do pulso de $12 \mu \mathrm{s}$ e tempo de aquisição (at) de 14,8 s (Figura 4.3). Foram realizadas 256 médias por medida, e os espectros continham $64 \mathrm{~K}$ pontos, com janela espectral de $1400 \mathrm{~Hz}$.Para estas medidas, não foi utilizada uma sequência com pulso de $90^{\circ}$ para que fosse evitada a saturação do pré-amplificador do espectrômetro devido ao intenso sinal da água residual.

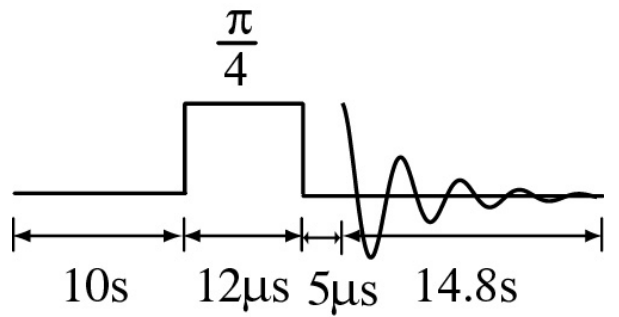

Figura 4.3: Representação esquemática da sequência de $\pi / 4$ usada nas amostras de quadríceps.

As amostras de diafragma foram submetidas a uma sequência de pulso de $90^{\circ}$, uma vez que apresentavam concentração muito menor, não ocorrendo saturação do receptor. A sequência utilizada consistia em um pulso com duração de $24 \mu \mathrm{s}$, tempo de espera (d1) de $10 \mathrm{~s}$, e tempo de aquisição de 14,8 s (Figura 4.4). Os espectros continham $64 \mathrm{~K}$ pontos, e foram coletadas médias suficientes para que a razão sinal/ruído fosse maior ou igual a 60 . 


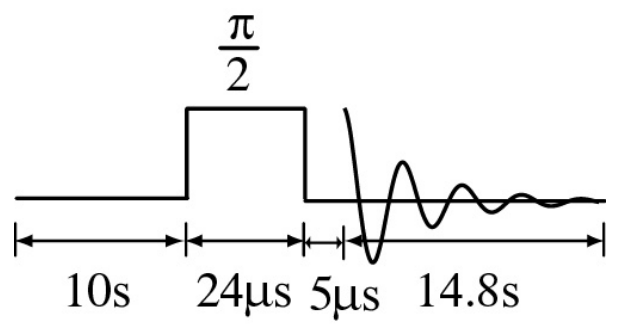

Figura 4.4: Representação esquemática da sequência de $\pi / 2$ usada nas amostras de diafragma.

\subsubsection{Espectroscopia bidimensional de correlação ho- monuclear}

Além das medidas de espectroscopia unidimensional de ${ }^{1} \mathrm{H}$ e ${ }^{13} \mathrm{C}$, foram realizados experimentos de espectroscopia bidimensional de ${ }^{1} \mathrm{H}$. Tais medidas foram realizadas a fim de auxiliar a identificação dos picos observados nos espectros unidimensionais. Os experimentos espectroscopia bidimensional de correlação homonuclear, chamados de experimentos COSY, são caracterizados pela aplicação de um pulso de $90^{\circ}$, seguido de um tempo de evolução variável chamado $t_{1}$ e por um novo pulso, que pode ser de $90^{\circ}$ ou de $45^{\circ}$. No primeiro caso, o experimento é chamado de COSY-90, enquanto no segundo caso o experimento é chamado de COSY-45.

O primeiro pulso aplicado, de $90^{\circ}$, faz com que a magnetização resultante se oriente no plano transversal. Durante o tempo de evolução $t_{1}$ a magnetização no plano transversal evolui sob influência de diversos fatores, entre eles o desvio químico e o acoplamento spin-spin, para em seguida um novo pulso ser aplicado e o sinal ser detectado. O tempo de evolução $t_{1}$ sofre um incremento $\Delta t_{1}$ a cada medida. Aplicando-se a transformada de Fourier aos sinais adquiridos são gerados espectros no domínio de frequência chamado $F_{2}$. Observa-se que a amplitude destes espectros será modulada de acordo com o tempo de evolução $t_{1}$ ao qual cada medida foi submetida. Aplicando-se uma nova transformada de Fourier a este conjunto de espectros modulados pela amplitude temos um sinal no domínio de frequência $F_{1}$, contendo a informação dos mecanismos efetivos durante o tempo $t_{1}$. Nos espectros COSY, os dois eixos de frequência $F_{1}$ e $F_{2}$ contêm informação sobre os desvios químicos. Há picos posicionados sobre a diagonal principal e picos fora da 
mesma, os chamados picos cruzados, que indicam a existência de acoplamento escalar.

Para um sistema de dois núcleos AX, o espectro COSY será composto por sinais sobre a diagonal principal nas coordenadas $\left(\nu_{A}, \nu_{A}\right)$ e $\left(\nu_{X}, \nu_{X}\right)$, e por picos cruzados com as coordenadas $\left(\nu_{A}, \nu_{X}\right)$ e $\left(\nu_{X}, \nu_{A}\right)$. Os picos cruzados correlacionam os picos observados nas frequências $\nu_{A}$ e $\nu_{X}$ nos espectros unidimensionais, e indicam acoplamento escalar entre os núcleos A e X. Assim, os picos cruzados indicam que os picos observados nas frequências correspondentes do espectro unidimensional pertencem à mesma molécula, auxiliando na identificação dos metabólitos presentes nas amostras. Nos experimentos COSY-45 a intensidade dos sinais sobre a diagonal principal é reduzida, o que pode facilitar a interpretação dos resultados. Entretanto, a intensidade dos picos cruzados também é reduzida.

Foram realizados experimentos bidimensionais de correlação homonuclear tanto em parte das amostras de quadríceps femural como em parte das amostras de diafragma, com o objetivo de auxiliar na identificação dos metabólitos contidos nas amostras. Nas amostras de quadríceps foram adquiridos espectros bidimensionais com a sequência COSY90 de 15 amostras (5 amostras de $m d x$ de 3 meses, 3 amostras de $m d x$ de 6 meses, 1 amostra de camundongo de controle de 3 meses e 6 amostras de camundongos de controle de 6 meses) e com a sequência COSY45 de uma amostra (mdx28 - 3 meses). Nas amostras de diafragma, foram adquiridos espectros bidimensionais com a sequência COSY45 de 24 amostras (8 amostras de $m d x$ de 3 meses, 5 amostras de $m d x$ de 6 meses, 8 amostras de camundongos de controle de 3 meses e 3 amostras de camundongos de controle de 6 meses).

Os parâmetros utilizados na sequência COSY90 foram: tempo de aquisição $1,46 \mathrm{~s}, 4 \mathrm{~K}$ pontos, janela espectral de $1400 \mathrm{~Hz}$, primeiro pulso com duração de $20 \mu \mathrm{s}$, segundo pulso com duração de $20 \mu \mathrm{s}$, tempo de espera de $5 \mathrm{~s}, 52$ transientes. Para a segunda dimensão, codificada entre os dois pulsos de $90^{\circ}$, foi utilizada a mesma janela espectral, e o número de incrementos foi 72 . A sequência está representada na Figura 4.5.

Os parâmetros utilizados na sequência COSY45 foram: tempo de aquisição $1,46 \mathrm{~s}, 4 \mathrm{~K}$ pontos, janela espectral de $1400 \mathrm{~Hz}$, duração do primeiro pulso (pw) $20 \mu \mathrm{s}$, duração do segundo pulso (p1) de $10 \mu \mathrm{s}$, tempo de espera de $5 \mathrm{~s}, 44$ transientes. Para a segunda dimensão, codificada entre os dois pulsos de $90^{\circ}$, a janela espec- 


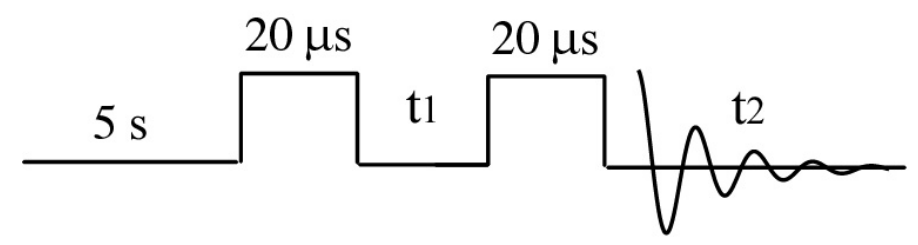

Figura 4.5: Representação esquemática da seqüência COSY-90.

tral foi de $1400 \mathrm{~Hz}$ e o número de incrementos era 64 (número de pontos do sinal na segunda dimensão). A representação esquemática da sequência COSY45 encontra-se na Figura 4.6. A sequência COSY-45 produz um sinal de menor intensidade na diagonal principal, com relação ao sinal dos picos cruzados. Desta maneira, picos próximas à diagonal principal podem ser melhor visualizado. Entretanto, no experimento realizado na amostra de quadríceps, foi observada uma intensidade menor de sinal em todos os picos, o que dificultou a interpretação dos resultados. Desta forma, foi feita a opção de se utilizar a sequência COSY-90 nas demais amostras de quadríceps. Já para as amostras de diafragma optou-se pela sequência COSY45.

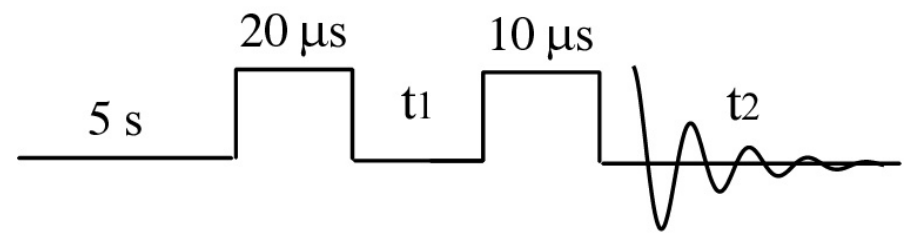

Figura 4.6: Representação esquemática da seqüência COSY-45.

Determinação do pulso $\pi / 2$

Para a determinação da duração do pulso de $\pi / 2$ a ser utilizado nos experimentos bidimensionais, foi programada uma sequência de pulso com 31 diferentes valores de duração de pulso ( $p w$ - pulse width de 0 a $60 \mu \mathrm{s}$, com diferença de $2 \mu \mathrm{s}$, Figura 4.7). A sequência de pulso foi aplicada a uma das amostras ( $M d x 37$-diafragma). A duração do pulso de $\pi / 2$ foi escolhido de modo a maximizar a amplitude do pico de TSP, valor que corresponde a $20 \mu$ A Figura 
4.8 mostra o sinal referente ao TSP após aplicação de pulsos com diferentes durações.

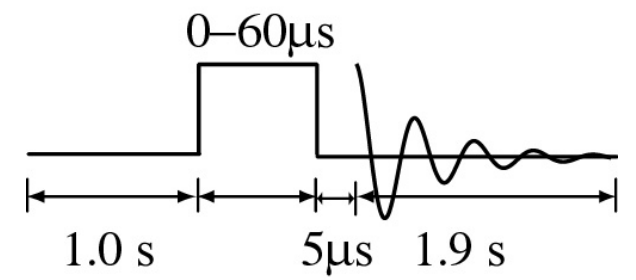

Figura 4.7: Representação esquemática da sequência de pulsos utilizada para a determinação da duração do pulso de $\pi / 2$.

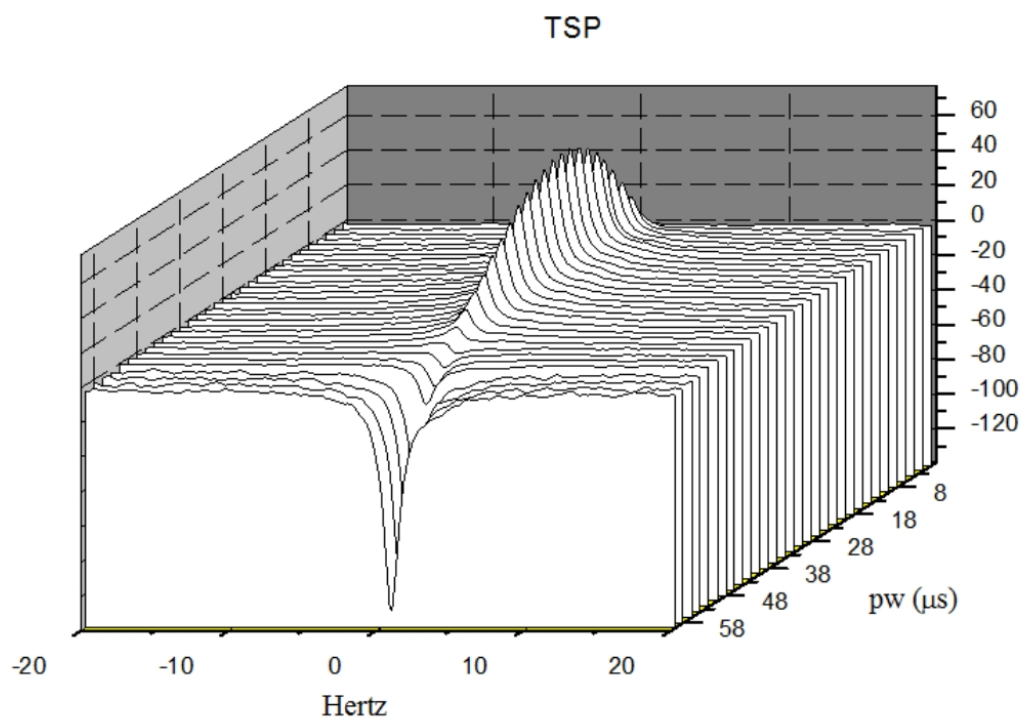

Figura 4.8: Intensidade do pico de TSP para cada valor de duração de pulso (pw) utilizado.

\subsection{Processamento dos dados e análise esta- tística}

Os espectros unidimensionais, após transformada de Fourier, tiveram sua fase ajustada e passaram por correção da linha de base. 
A aquisição e o tratamento dos sinais foram realizados com o software VNMR (Varian), o mesmo empregado na geração dos sinais FID pelo espectrômetro. Os espectros tratados foram exportados e a região do espectro contendo o sinal da água foi excluída (região entre 4,6 e 5,1 ppm). A região excluída não prejudica a análise dos espectros, pois alterações no metabólito possivelmente afetado, o lactato, não foram consideradas confiáveis devido à troca de metabolismo aeróbico para anaeróbico após da eutanásia dos animais. Os espectros foram normalizados pela área do pico de TSP (-0,07 a 0,07 ppm), a fim de se ajustar todos a uma mesma escala vertical, e posteriormente cada espectro foi normalizado pela sua área total, excluindo-se as regiões dos picos de TSP e da água. Esta segunda normalização teve como objetivo eliminar diferenças de concentração entre as amostras. Foram calculadas as integrais dos picos observados com razão sinal/ruído apreciável e as diferenças significativas nos valores encontrados foram identificadas com análise de variância (ANOVA). Tanto a análise de variância como os cálculos de integrais e normalizações foram feitos com o programa Microcal Origin.

Adicionalmente, os valores de integrais foram analisados pelo métodos Principal Component Analysis (PCA), com o uso do software SIMCA-P+11. Em linhas gerais, o método PCA consiste na construção de novas variáveis ortogonais (ou seja, não correlacionadas) a partir de combinações lineares das variáveis originais. As novas variáveis calculadas são chamadas de componentes principais, e são construídas de modo a representar o máximo da informação inicial em um menor número de variáveis. O método PCA é um método de análise estatística capaz de agrupar variáveis com comportamentos semelhantes dentro de uma amostra, e tem aplicação especialmente em casos onde o número elevado de variáveis dificulta a análise tradicional. Para encontrar as componentes principais calculam-se os autovetores da matriz de covariância e os autovalores correspondentes. Toma-se como primeira componente principal (PC1) o autovetor que possuir o maior autovalor associado, e assim consecutivamente até que todos os autovetores sejam ordenados. A porcentagem de informação (variância) contida em cada componente principal é proporcional ao seu autovalor. Assim, a primeira componente principal é o autovetor na direção que contém mais informações a respeito do conjunto de dados original (maior variância). Desta maneira é possível concentrar grande parte da informação inicial em poucas componentes principais, o 
que simplifica a análise e a identificação de padrões. Os elementos dos autovetores são chamados de loadings e representam a contribuição de cada uma das variáveis originais na construção das componentes principais. $\mathrm{O}$ produto escalar dos dados originais pelos autovetores produz os chamados scores. Os gráficos de score mostram as projeções dos dados de cada uma das observações originais da direção das componentes principais selecionadas. No caso em que poucas componentes principais contém grande parte da informação inicial, é possível observar simplificações acuradas dos dados originais em um menor número de dimensões nos gráficos de score das primeiras componentes principais. Nos gráficos de loading correspondentes, pode-se detectar quais são as variáveis responsáveis pelos agrupamentos observados nos gráficos de score (Apêndice A). Após a aplicação do método PCA foram selecionados os gráficos de score mais expressivos para cada comparação entre grupos de animais. Os gráficos de score das duas primeiras componentes não mostraram em todos os casos a melhor separação entre os grupos, apesar de estas serem as duas componentes que contêm a maior porcentagem de variabilidade considerando todos os animais. Isto ocorre pois o método PCA não utiliza como entrada a informação dos grupos aos quais cada animal pertence. Assim, as componentes principais podem representar uma grande variabilidade em um mesmo grupo de animais, não sendo assim capazes de distinguir grupos diferentes.

Para a análise dos gráficos de loading, foram consideradas relevantes as variáveis com valores maiores ou iguais a $50 \%$ do valor máximo obtido para cada uma das componentes principais com diferença significativa entre os grupos comparados. Nos casos em que duas ou mais componentes se mostraram significativas, foram adotadas como variáveis relevantes aquelas que se encontravam no mesmo quadrante do grupo de interesse.

\subsection{Análise Histológica}

O tecido próprio para histologia foi cortado em criostato, em cortes transversais de $8 \mu \mathrm{m}$ de espessura. Os cortes foram dispostos em lâminas cobertas com polilisina e mantidos a $-70^{\circ} \mathrm{C}$ até a sua coloração com Hematoxilina-Eosina (HE). As lâminas selecionadas ficaram em temperatura ambiente por aproximadamente 1 hora antes da coloração. Em seguida foram coradas em hematoxilina 
filtrada por 3 minutos, e lavadas em água corrente por mais 10 minutos. Após a coloração com hematoxilina foi feita a coloração com eosina por 3 minutos, seguida por lavagem em água corrente até que todo o excesso de corante fosse eliminado. Os cortes foram fixados em ácido acético, desidratadas em álcool etílico e xilol e montadas com Bálsamo do Canadá. A preparação das lâminas e a análise histológica foram realizadas no Centro de Estudos do Genoma Humano - Instituto de Biociências da USP. 


\section{Capítulo 5}

\section{Resultados}

Os espectros unidimensionais de ${ }^{1} \mathbf{H}$ das amostras de diafragma e de quadríceps femural foram adquiridos, sendo que o tempo médio de cada medida era de $\mathbf{2}$ horas. Visualmente não foi possível identificar diferenças marcantes entre os grupos de camundongos $\boldsymbol{m d x}$ e controle com três e seis meses tanto para as amostras de quadríceps (Figuras 5.1 e 5.3) como para as amostras de diafragma (Figura 5.2) após o tratamento dos espectros. Esta observação está de acordo com resultados observados na literatura $[76,12]$ e indica que a ausência de distrofina não provoca alterações nos tipos de metabólitos produzidos ou nas vias metabólicas ativas nestes músculos dos camundongos $m d x$. A normalização pela área total se mostrou importante uma vez que as amostras liofilizadas apresentaram grande variação de massa. As amostras liofilizadas de quadríceps apresentaram massas que variavam entre $3,3 \mathrm{mg}$ e $10,8 \mathrm{mg}$, enquanto as amostras liofilizadas de diafragma apresentaram massa entre 0,7 $\mathrm{mg}$ e 1,7 mg. Uma vez que as amostras de diafragma se apresentavam em concentração mais baixa que as amostras de quadríceps, não foi possível observar sinais com razão sinal/ruído apreciável na região do espectro com deslocamento químico maior que o da água nas amostras de diafragma. 
(a)
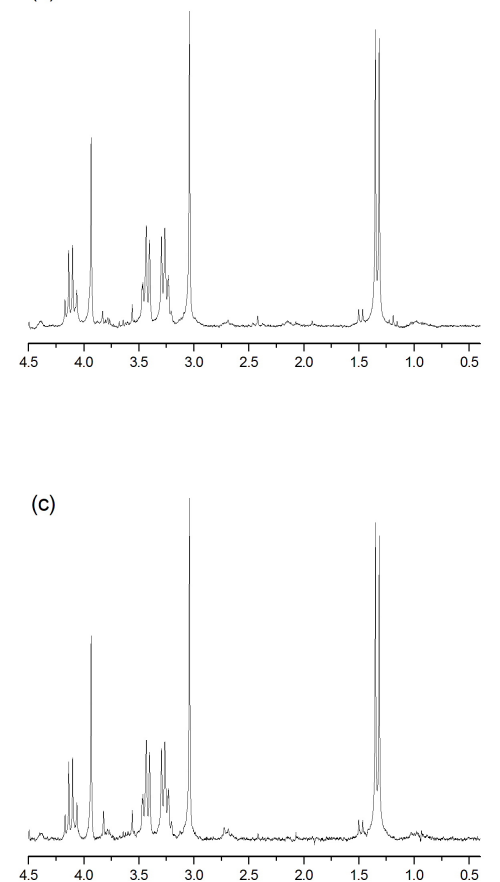

(b)

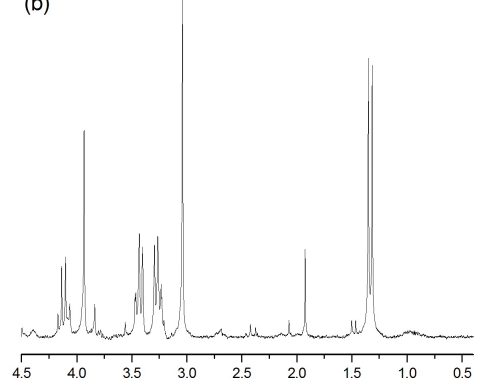

(d)

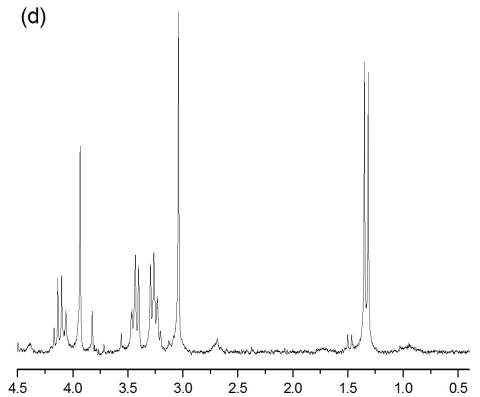

Figura 5.1: Espectros de ${ }^{1} \mathrm{H}$ RMN de amostras de quadríceps de camundongos $m d x$ e de controle com idades diferentes (deslocamentos químicos menores que o da água, de $-0,5$ a 4,6 ppm). (a) $m d x 3$ meses; (b) $m d x 6$ meses; (c) Controle 3 meses; (d) Controle 6 meses. Deslocamentos químicos em ppm. O pico intenso observado em 1.9 ppm no espectro $b$ não foi observado consistentemente elevado nas amostras deste grupo. 

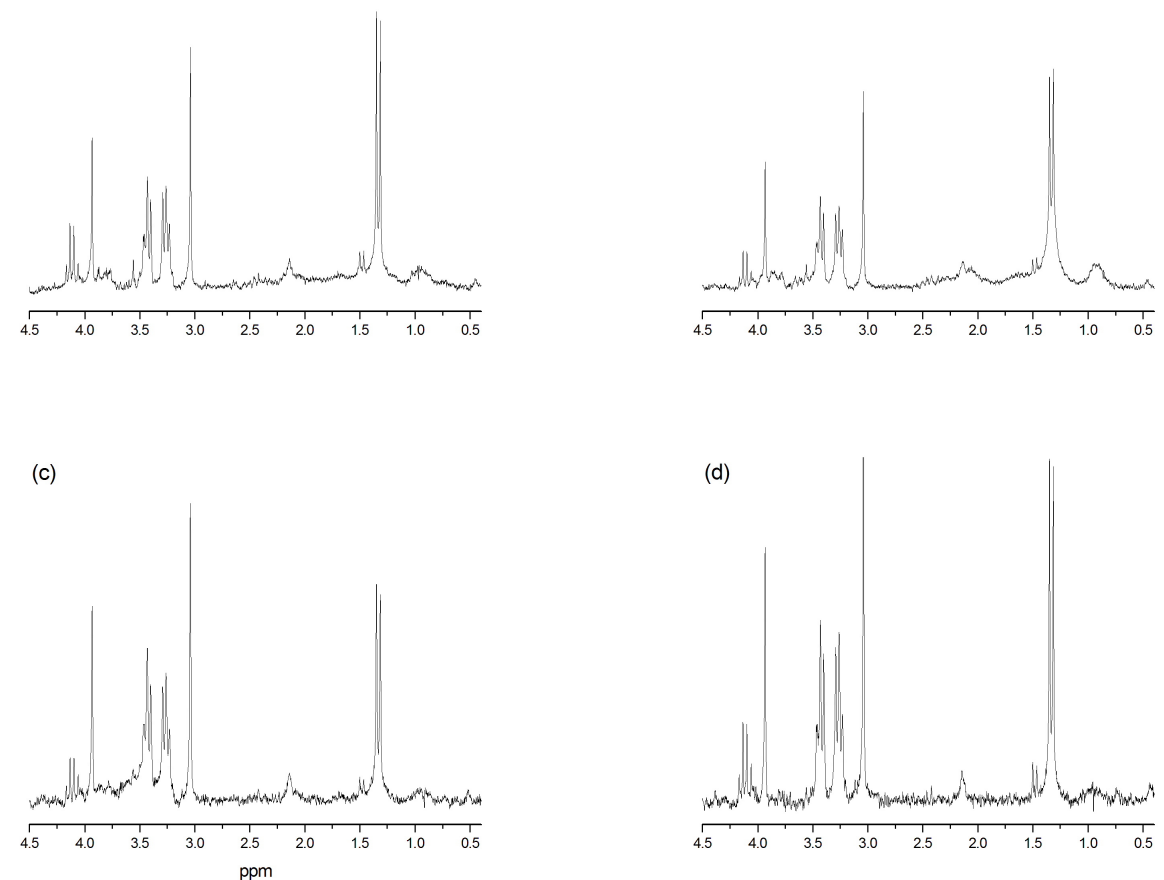

Figura 5.2: Espectros de ${ }^{1} \mathrm{H}$ RMN de amostras de diafragma de camundongos $m d x$ e de controle com idades diferentes (deslocamentos químicos menores que o da água, de $-0,5$ a 4,6 ppm). (a) mdx 3 meses; (b) $m d x 6$ meses; (c) Controle 3 meses; (d) Controle 6 meses. Deslocamentos químicos em ppm. 
(a)

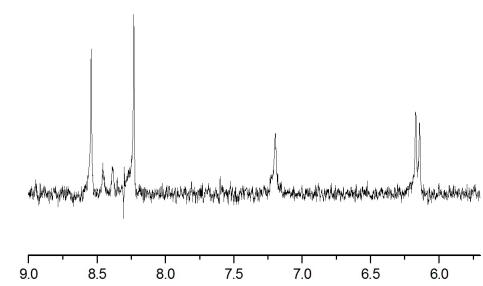

(c)

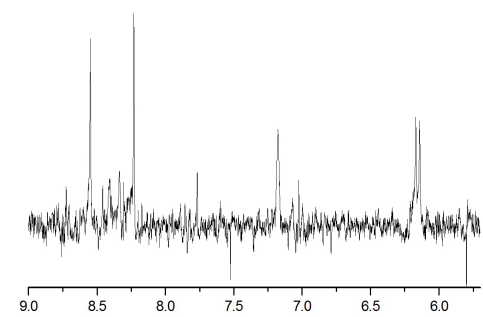

(b)

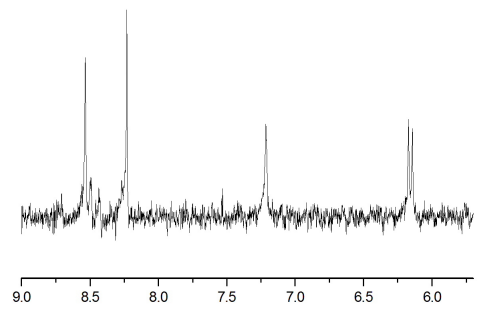

(d)

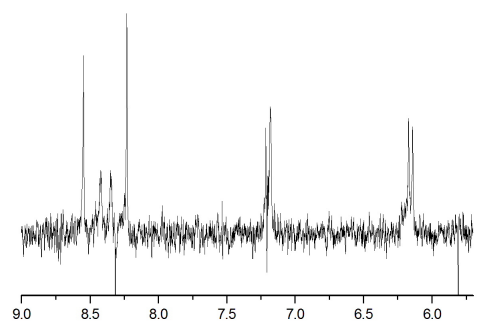

Figura 5.3: Espectros de ${ }^{1} \mathrm{H}$ RMN de amostras de quadríceps de camundongos $m d x$ e de controle com idades diferentes (deslocamentos químicos maiores que o da água, de 5,1 a 9,2 ppm). (a) $m d x 3$ meses; (b) $m d x 6$ meses; (c) Controle 3 meses; (d) Controle 6 meses. Deslocamentos químicos em ppm. 
Nos espectros unidimensionais de ${ }^{1} \mathbf{H}$ foram selecionados vinte e quatro picos observados com razão sinal/ruído apreciável (Tabela 5.1) e as integrais dos mesmos foram calculadas. Foram propostos metabólitos relacionados aos picos observados de acordo com dados de literatura $[10,73,14,85]$ (Figura 5.4) e com auxílio dos espectros bi-dimensionais (Figura 5.5). Os valores das integrais dos picos foram comparados entre os camundongos $m d x$ e os de controle e entre os animais de mesma linhagem com idades diferentes (controle de 3 meses versus controle de 6 meses; $m d x$ de 3 meses versus $m d x$ de 6 meses).

As medidas de ${ }^{1} \mathrm{H}$ RMN das amostras de quadríceps foram feitas antes das medidas das amostras de diafragma, na intenção de se preservar as amostras de diafragma para utilização depois da padronização da metodologia. A sequência de pulsos utilizada nas medidas das amostras de quadríceps não se mostrou a mais apropriada para as amostras de diafragma, que apresentavam concentração muito mais baixa. Uma vez que as sequências de pulsos utilizadas nos diferentes tecidos não foi a mesma não foi possível comparar diretamente os espectros de quadríceps e de diafragma na busca por possíveis diferenças metabólicas entre os dois músculos devido ao grau de afecção pela distrofia.

\subsubsection{Comparação direta das integrais dos picos obser- vados}

Os valores das integrais foram comparados diretamente entre todos os camundongos $m d x$ e todos os camundongos de controle. Nas amostras de quadríceps foi observado um aumento nos picos 2 ( $\beta$-hidroxibutirato, $p \leq 0,001$ ), 3 (isoleucina, $p \leq 0,05), 7$ (glutamato, $p \leq 0,05)$, 8 (glutamina / metionina, $p \leq 0,05$ ), 9 (glutamato, $p \leq 0,05)$ e 11 (glutamina, $p \leq 0,001$ ) nos camundongos $\boldsymbol{m d x}$ em relação aos camundongos de controle. Os camundongos $\boldsymbol{m d x}$ apresentaram uma redução nos picos 1 (lipídios / isoleucina, $p \leq 0,05), \mathbf{1 2}$ (carnosina / metionina, $p \leq 0,001$ ), 18 (glutamato / glicose / glicerol / metionina / glutamina / alanina, $p \leq 0,05), 21$ (AMP/ATP, $p \leq 0,001), 22$ (carnosina, $p \leq 0,01)$ e 23 (AMP/ADP/ATP, $p \leq 0,001)$ em relação aos camundongos de controle (Figura 5.6).

Nas amostras de diafragma os camundongos $m d x$ apresentaram aumento significativo nas integrais dos picos 9 (glutamato, 


\begin{tabular}{|c|c|c|c|}
\hline Pico & Início (ppm) & Término (ppm) & metabólito \\
\hline 1 & 0,776 & 1,095 & lipídios / isoleucina \\
\hline 2 & 1,143 & 1,162 & $\beta$-hidroxibutirato \\
\hline 3 & 1,174 & 1,196 & isoleucina \\
\hline 4 & 1,196 & 1,405 & lactato \\
\hline 5 & 1,445 & 1,518 & alanina \\
\hline 6 & 1,872 & 1,951 & acetato \\
\hline 7 & 2,048 & 2,082 & glutamato \\
\hline 8 & 2,080 & 2,186 & glutamina / metionina \\
\hline 9 & 2,345 & 2,366 & glutamato \\
\hline 10 & 2,366 & 2,386 & glutamato / succinato \\
\hline 11 & 2,407 & 2,434 & glutamina \\
\hline 12 & 2,549 & 2,767 & metionina / carnosina \\
\hline 13 & 3,008 & 3,071 & creatina / carnosina \\
\hline 14 & 3,171 & 3,505 & taurina / carnosina / carnitina \\
\hline 15 & 3,532 & 3,582 & glicina / glicerol \\
\hline 16 & 3,633 & 3,653 & glicerol \\
\hline 17 & 3,690 & 3,749 & glicose / isoleucina \\
\hline 18 & 3,777 & 3,866 & $\begin{array}{l}\text { glutamato / glicose / glicerol / } \\
\text { glutamina / metionina / alanina }\end{array}$ \\
\hline 19 & 3,903 & 3,975 & creatina \\
\hline 20 & 4,015 & 4,191 & lactato / $\beta$-hidroxibutirato \\
\hline 21 & 6,118 & 6,210 & AMP / ATP \\
\hline 22 & 7,092 & 7,266 & carnosina \\
\hline 23 & 8,206 & 8,255 & AMP / ADP / ATP \\
\hline 24 & 8,512 & 8,594 & $\mathrm{AMP} / \mathrm{ADP} / \mathrm{ATP}$ \\
\hline
\end{tabular}

Tabela 5.1: Região de integração dos picos selecionados nos espectros de ${ }^{1} \mathrm{H}-\mathrm{RMN}$ e metabólitos associados. 


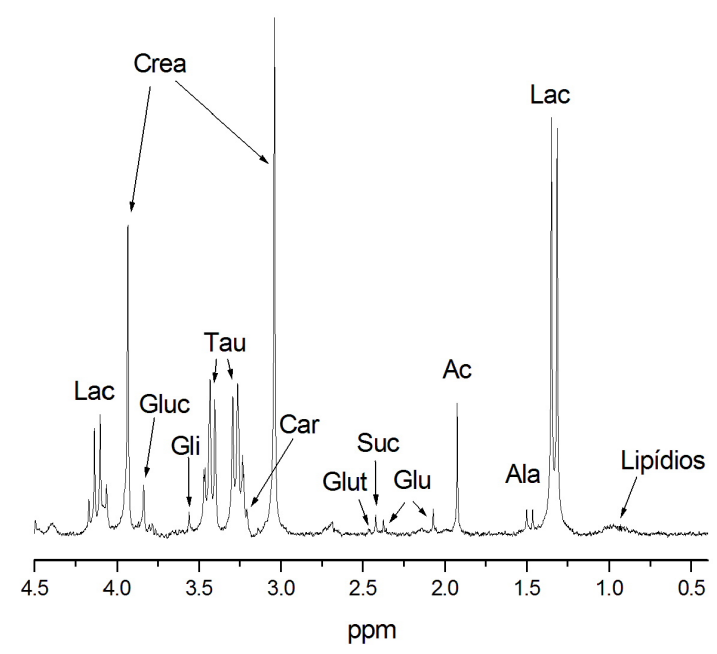

Figura 5.4: Espectro de ${ }^{1} \mathrm{H}$ RMN de camundongos $m d x$ com seis meses de idade mostrando alguns dos picos identificados. Região de deslocamentos químicos menores que o da água (de 0,5 a 4,6 ppm). Lac: lactato, Ala: alanina; Ac: acetato, Glu: glutamato, Suc: succinato, Glut: glutamina, Crea: creatina, Car: carnitina, Tau: taurina, Gli: glicina, Gluc: glicose.

$p \leq 0,01), 10$ (glutamato / succinato, $p \leq 0,001), \mathbf{1 1}$ (glutamina, $p \leq$ 0,001), 15 (glicina, $p \leq 0,05), \mathbf{1 6}$ (glicerol, $p \leq 0,01$ ), 17 (isoleucina / glicose, $p \leq 0,001$ ), $\mathbf{1 8}$ (glutamato / glicose / glicerol / metionina / glutamina / alanina, $p \leq 0,001$ ) e 20 (lactato / $\beta$-hidroxibutirato, $p \leq 0,05)$ em relação aos camundongos de controle. Os camundongos $\boldsymbol{m d x}$ apresentaram redução nos valores de integrais dos picos 13 (creatina / carnosina, $p \leq 0,001)$, 21 (AMP/ADP/ATP, $p \leq 0,05)$, 22 (carnosina, $p \leq 0,01)$ e $23(\mathrm{AMP} / \mathrm{AD} / \mathrm{ATP}, p \leq 0,05)$ (Figura 5.6).

Além da comparação entre todos os camundongos $m d x$ e todos os camundongos de controle, foi feita separadamente a comparação entre os camundongos $m d x$ de 3 meses e os camundongos de controle de mesma idade e a comparação entre os camundongos $\boldsymbol{m d x}$ com 6 meses e os camundongos de controle com idade correspondente.

Para as amostras de quadríceps, os camundongos $m d x$ de 3 meses apresentaram elevação nos valores das integrais dos picos 2 ( $\beta$-hidroxibutirato, $p \leq 0,05$ ), 3 (isoleucina, $p \leq 0,05$ ) , 7 (glutamato, 


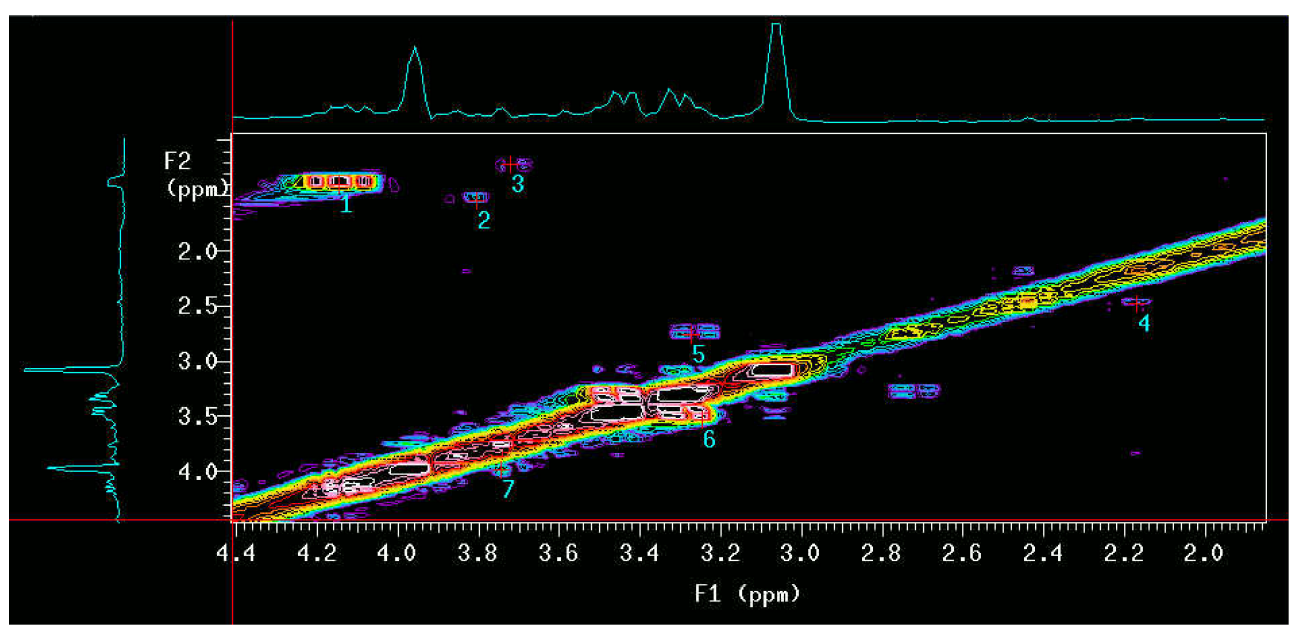

Figura 5.5: Espectro bi-dimensional de amostra de quadríceps de camundongo $m d x$ com 6 meses de idade. 1: lactato, 2: alanina, 3: isoleucina, 4: glutamina, 5: carnosina, 6: taurina, 7: glicose.
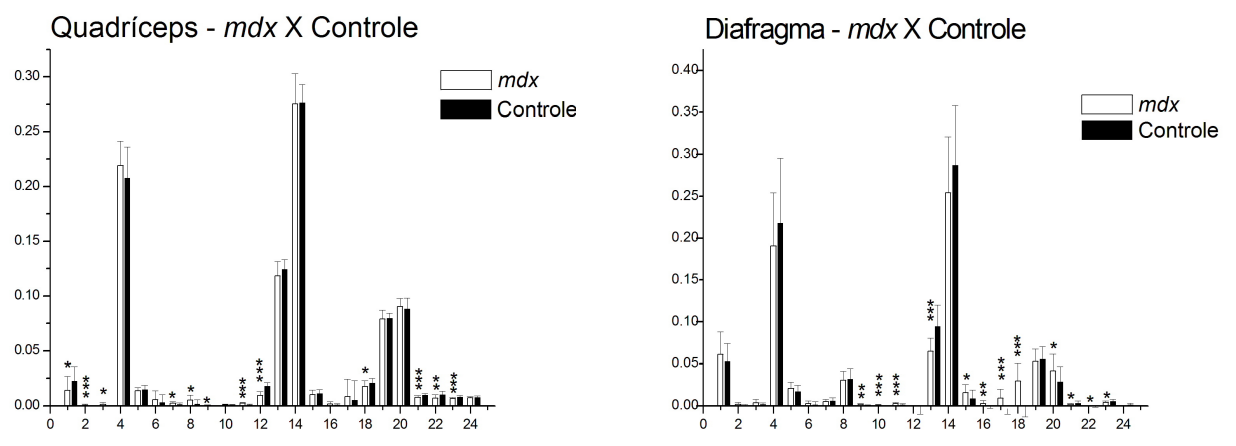

Figura 5.6: Médias \pm desvio padrão dos valores de integral dos picos observados nas amostras de quadríceps (à esquerda) e diafragma (à direita) de camundongos $m d x$ e de controle. As diferenças significativas estão destacadas com asteriscos. $*: p \leq 0,05$, $* *: p \leq 0,01, * * *: p \leq 0,001$. 
$p \leq 0,01), \mathbf{9}$ (glutamato, $p \leq 0,05), \mathbf{1 1}$ (glutamina, $p \leq 0,05)$ e 17 (isoleucina / glicose, $p \leq 0,05)$ quando comparados aos camundongos de controle de mesma idade. Os camundongos $m d x$ de 3 meses apresentaram redução nos valores das integrais dos picos 12 (carnosina / metionina, $p \leq 0,001$ ), $\mathbf{1 3}$ (creatina / carnosina, $p \leq 0,01, \mathbf{1 9}$ (creatina, $p \leq 0,05), 21$ (AMP/ATP, $p \leq 0,001), 22$ (carnosina, $p \leq 0,01$ ), 23 (AMP/ADP/AMP, $p \leq 0,001)$ e 24 (AMP/ADP/AMP, $p \leq 0,01)$ quando comparados aos camundongos de controle de mesma idade. Já para as amostras de diafragma, os camundongos $\boldsymbol{m d x}$ apresentaram elevação nos valores das integrais dos picos 17 (isoleucina / glicose, $p \leq 0,05)$ e $\mathbf{1 8}$ (glutamato / glicose / glicerol / metionina / glutamina / alanina, $p \leq 0,01$ ), e redução no pico 21 (AMP/ATP, $p \leq 0,01$ ) (Figura 5.7).
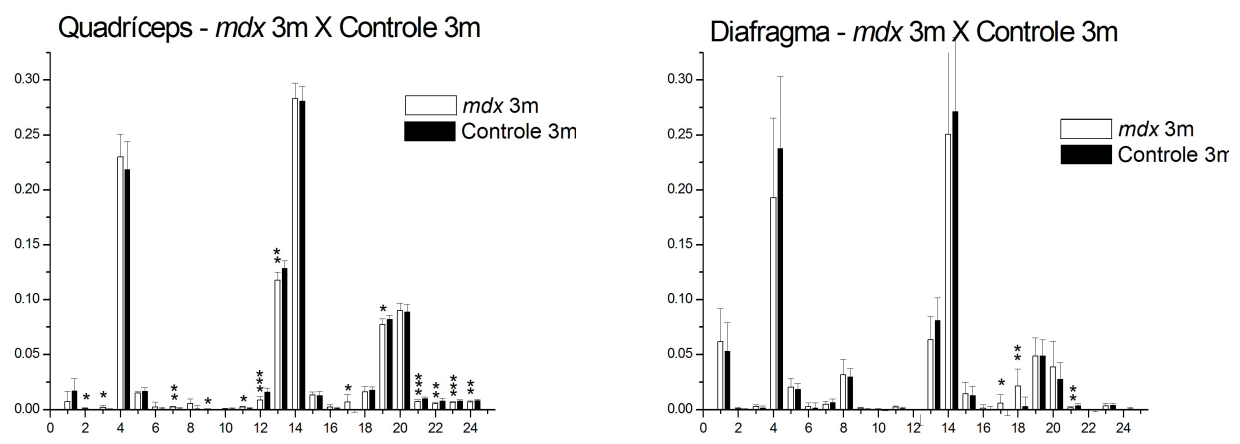

Figura 5.7: Médias \pm desvio padrão dos valores de integral dos picos observados nas amostras de quadríceps (à esquerda) e diafragma (à direita) de camundongos $m d x$ e de controle com 3 meses de idade. As diferenças significativas estão destacadas com asteriscos. $*: p \leq 0,05, * *: p \leq 0,01, * * *: p \leq 0,001$.

Na comparação entre camundongos $m d x$ com 6 meses e os camundongos de controle de mesma idade, para as amostras de quadríceps foi possível observar aumento nos valores das integrais dos picos 2 ( $\beta$-hidroxibutirato, $p \leq 0,05)$ e 11 (glutamina, $p \leq 0,05$ ), e redução nos valores das integrais dos picos 1 (lipídios / isoleucina, $p \leq 0,001$ ), 12 (carnosina / metionina, $p \leq 0,001$ ), 18 (glutamato / glicose / glicerol / metionina / glutamina / alanina, $p \leq 0,05)$, 21 (AMP/ATP, $p \leq 0,05)$ e 22 (carnosina, $p \leq 0,05)$ em relação aos valores observados para os camundongos de controle. Para as amostras de diafragma, os camundongos $\boldsymbol{m d x}$ apresentaram aumento nos valores das integrais dos picos 9 (glutamato, $p \leq 0,01$ ), 
10 (glutamato / succinato, $p \leq 0,001$ ), 11 (glutamina, $p \leq 0,01$ ), 15 (glicina, $p \leq 0,01$ ), 16 (glicerol, $p \leq 0,001$ ), 17 (isoleucina / glicose, $p \leq 0,001$ ) e $\mathbf{1 8}$ (glutamato / glicose / glicerol / metionina / glutamina / alanina, $p \leq 0,001)$, e redução nos valores das integrais dos picos 13 (creatina / carnosina, $p \leq 0,001$ ) e 23 (AMP/ADP/ATP, $p \leq 0,01)$ em relação aos valores obtidos para os camundongos de controle de mesma idade (Figura 5.8).
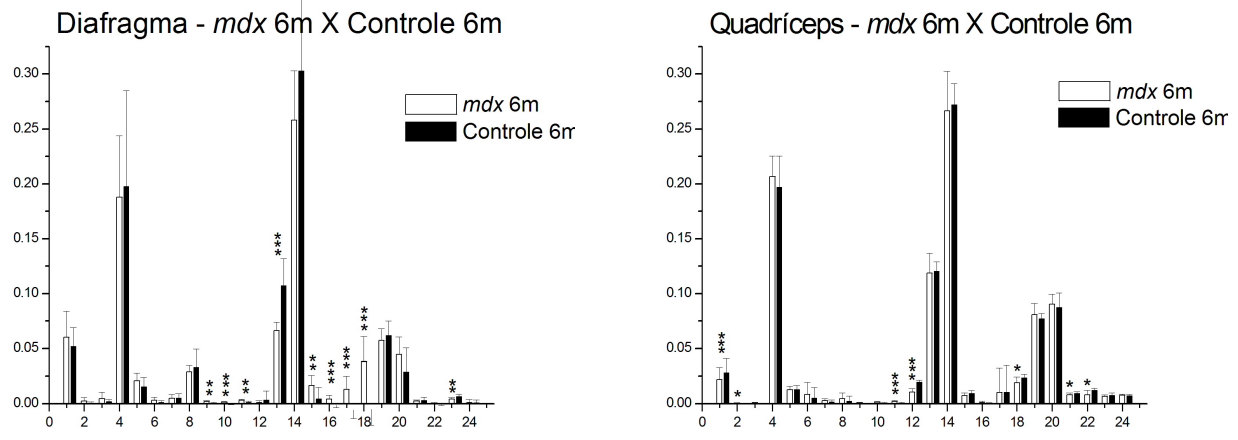

Figura 5.8: Médias \pm desvio padrão dos valores de integral dos picos observados nas amostras de quadríceps (à esquerda) e diafragma (à direita) de camundongos $m d x$ e de controle com 6 meses de idade. As diferenças significativas estão destacadas com asteriscos. $*: p \leq 0,05, * *: p \leq 0,01, * * *: p \leq 0,001$.

Foram comparadas as integrais dos picos observados entre os camundongos de controle com 3 e 6 meses de idade a fim de se observar possíveis alterações metabólicas provocadas pelo avanço da idade. Nas amostras de quadríceps observou-se nos camundongos com 3 meses de idade um aumento nos valores das integrais dos picos 5 (alanina, $p \leq 0,05), \mathbf{1 1}$ (glutamina, $p \leq 0,001$ ), 13 (creatina / carnosina $p \leq 0,05), 15$ (glicina, $p \leq 0,05)$, 16 (glicerol, $p \leq 0,05$ ) e 19 (creatina / glicose, $p \leq 0,05$ ) em relação aos camundongos de controle com 6 meses de idade. Os camundongos de 3 meses de idade apresentaram redução nos valores das integrais dos picos 12 (carnosina / metionina, $p \leq 0,05$ ), 18 (glutamato / glicose / glicerol / metionina / glutamina / alanina, $p \leq 0,001$ ) e 22 (carnosina, $p \leq 0,001$ ) (Figura 5.9). Na comparação entre as amostras de diafragma de camundongos de controle idades diferentes foi observada redução nos valores das integrais dos picos 13 (creatina / carnosina, $p \leq 0,05), 19$ (creatina / glicose, $p \leq 0,05)$ e 23 (AMP/ADP/ATP, $p \leq 0,01)$ nos camundongos de 3 meses de idade em relação aos 
camundongos com 6 meses de idade (Figura 5.9).
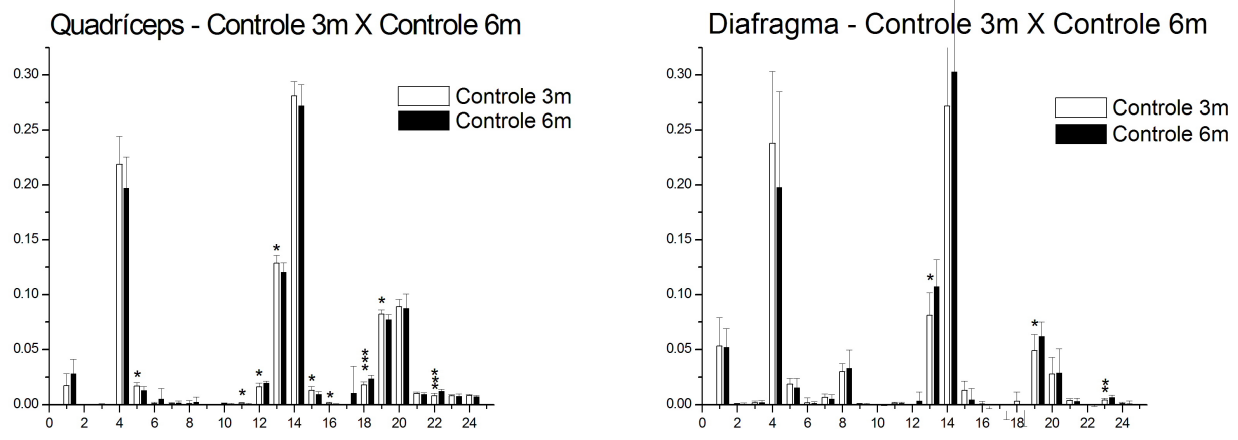

Figura 5.9: Médias \pm desvio padrão dos valores de integral dos picos observados nas amostras de quadríceps (à esquerda) e de diafragma (à direita) de camundongos de controle com 3 e 6 meses de idade. As diferenças significativas estão destacadas com asteriscos. $*: p \leq 0,05, * *: p \leq 0,01, * * *: p \leq 0,001$.

Os valores de integrais dos picos observados também foram comparados entre os camundongos $m d x$ com idades diferentes. Para as amostras de quadríceps, os camundongos $m d x$ com 3 meses de idade apresentaram aumento nos valores das integrais dos picos 2 ( $\beta$-hidroxibutirato, $p \leq 0,05), 4$ (lactato, $p \leq 0,01$ ), 5 (alanina, $p \leq 0,05)$ e 15 (glicina, $p \leq 0,001$ ). Os picos 1 (lipídios / isoleucina) e 24 (AMP/ADP/ATP) apresentaram-se reduzidos $(p \leq 0,01$, $p \leq 0,05$ respectivamente) nos camundongos $\boldsymbol{m d x}$ com 3 meses de idade em relação aos camundongos $m d x \operatorname{com} 6$ meses de idade (Figura 5.10). Na comparação entre os camundongos $m d x$ de diferentes idades para as amostras de diafragma observou-se redução nos valores das integrais do pico 10 (glutamato / succinato, $p \leq 0,01$ ) nos animais com 3 meses de idade em relação aos animais com 6 meses de idade (Figura 5.10). Os demais picos não apresentaram diferença significativa.

\subsubsection{Análise das Componentes Principais (PCA)}

A aplicação do método PCA simplificou a obtenção de resultados sem que houvesse perda de qualidade dos mesmos. Na comparação entre todos os camundongos $m d x$ e todos os de controle, foi possível observar uma boa separação dos grupos tanto para as amostras de quadríceps como para as amostras de diafragma. Nas 

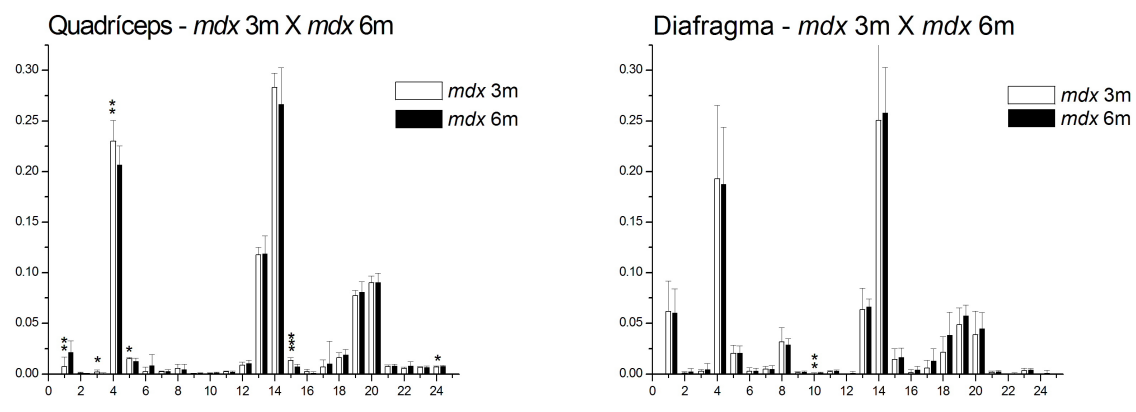

Figura 5.10: Médias \pm desvio padrão dos valores de integral dos picos observados nas amostras de quadríceps (à esquerda) e diafragma (à direita) de camundongos $m d x \operatorname{com} 3 \mathrm{e}$ 6 meses de idade. As diferenças significativas estão destacadas com asteriscos. $*: p \leq 0,05$, $* *: p \leq 0,01, * * *: p \leq 0,001$.

amostras de quadríceps, $62,9 \%$ da informação inicial estava contida nas quatro primeiras componentes principais. Dentre estas quatro componentes principais, a primeira (PC1) e a terceira componentes (PC3) apresentaram a melhor distinção entre os camundongos doentes e os de controle. Assim, foi analisado o gráfico de score com as projeções nas direções destas duas componentes principais (Figura 5.11), que apresentou um agrupamento dos camundongos $m d x$ no segundo quadrante, enquanto os camundongos de controle se apresentaram agrupados no quarto quadrante.

Além dos gráficos de score, o software SIMCA-P+11 gera os gráficos de loading, em que é possível verificar os pesos das variáveis iniciais na construção das componentes principais. Assim, é possível identificar as variáveis iniciais responsáveis pelos agrupamentos observados nos gráficos de score. No gráfico de loading para a comparação entre camundongos $m d x$ e de controle para as amostras de quadríceps foi possível identificar que os camundongos $m d x$ apresentaram aumento nos valores de integrais dos picos $7 \mathrm{e}$ 9, correspondentes ao glutamato, e 8 e 11, correspondentes à glutamina. Os camundongos $m d x$ apresentaram redução dos valores das integrais dos picos 12 (carnosina / metionina), 21 (AMP/ATP), 22 (carnosina), 23 (AMP/ADP/ATP) e 14 (taurina / carnosina / carnitina) (Figura5.12).

Para as amostras de diafragma, $70,1 \%$ da informação inicial estava contida nas cinco primeiras componentes principais. Entre elas, a primeira e a segunda componentes principais (PC1 e PC2) 


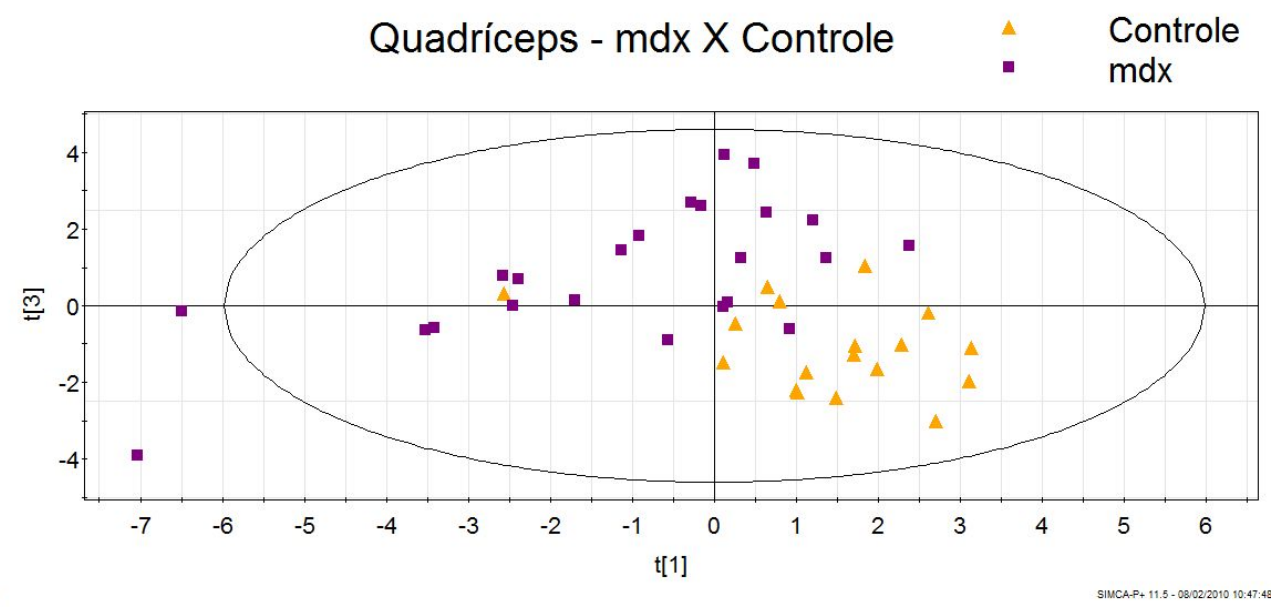

Figura 5.11: Gráfico de score para as componentes principais PC1 e PC3 mostrando as projeções das observações na direção destas componentes (t1 e t3) na comparação entre camundongos $m d x$ e de controle para as amostras de quadríceps.

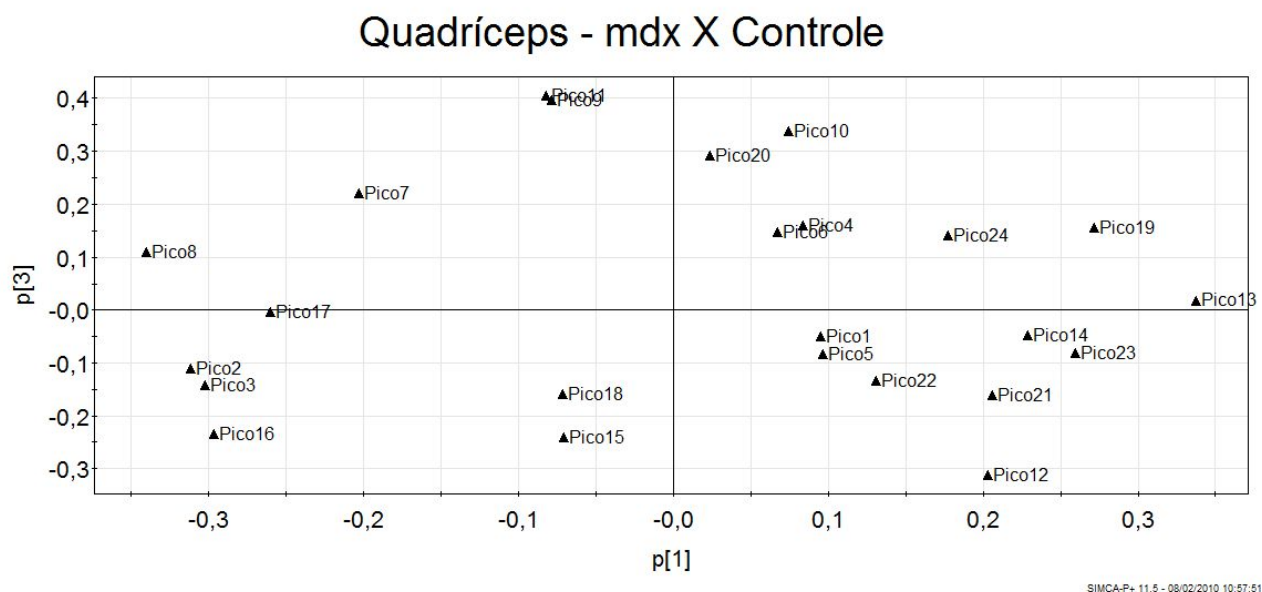

Figura 5.12: Gráfico de loading mostrando as contribuições de cada uma das variáveis originais na construção das componentes principais PC1 e PC3 (p1 e p3) na comparação entre camundongos $m d x$ e de controle para as amostras de quadríceps. 
apresentaram a melhor distinção entre os camundongos $m d x$ e os de controle. O gráfico de score de PC1XPC2 (Figura 5.13) mostra que os animais doentes se agruparam em torno do segundo quadrante enquanto os animais sadios se agruparam em torno do quarto quadrante.

O gráfico de loading correspondente mostrou que nas amostras de diafragma os camundongos $m d x$ apresentaram aumento nos valores das integrais dos picos 9 (glutamato), 10 (glutamato / succinato), 11 (glutamina), 16 (glicerol), 17 (isoleucina / glicose) e 18 (glutamato / glicose / glicerol / metionina / glutamina / alanina), e redução nos valores das integrais dos picos 13 (creatina / carnosina), 21 (AMP/ATP) e 23 (AMP/ADP/ATP) (Figura 5.14).

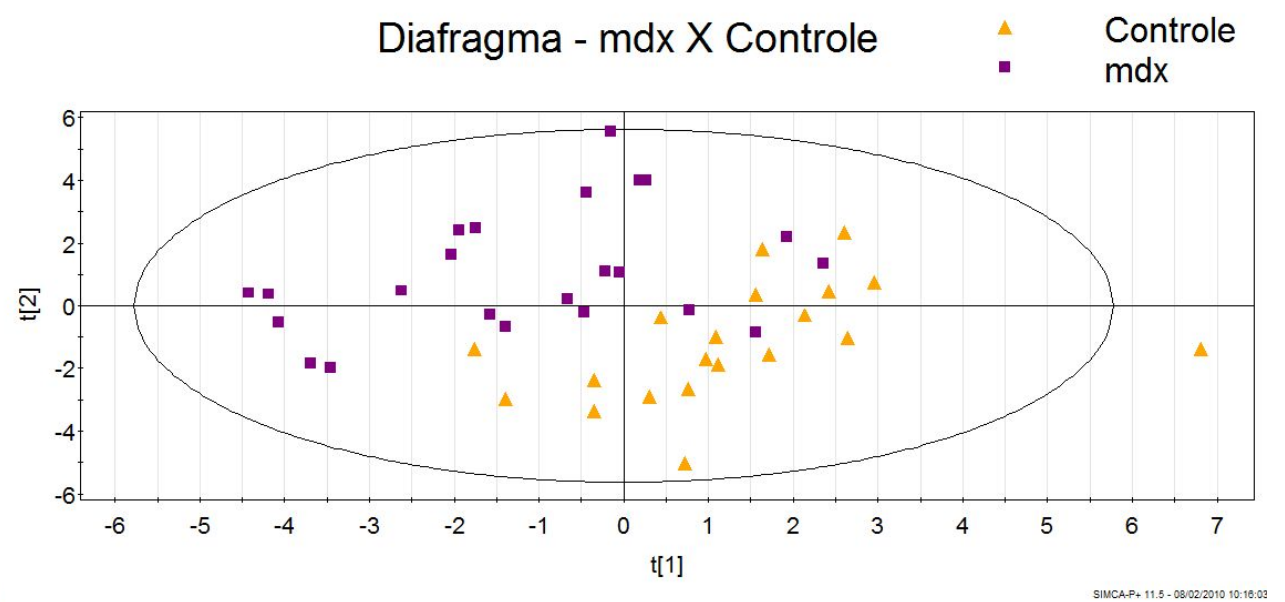

Figura 5.13: Gráfico de score para as componentes principais PC1 e PC2 na comparação entre camundongos $m d x$ e de controle para as amostras de diafragma mostrando as projeções das observações na direção destas componentes (t1 e t2).

O método de análise dos resultados pelas componentes principais se mostrou apropriado na distinção entre animais doentes e sadios tanto para as amostras de quadríceps como para as de diafragma. Adicionalmente foram comparados os camundongos $\boldsymbol{m d x}$ com 3 meses de idade com os camundongos de controle de mesma idade, e o mesmo foi feito com os animais de 6 meses de idade. Assim, pretendia-se caracterizar se o método era capaz de diferenciar animais em estágios diferentes da doença dos animais sadios de mesma idade.

Na comparação entre camundongos $m d x \operatorname{com} 3$ meses e os ca- 


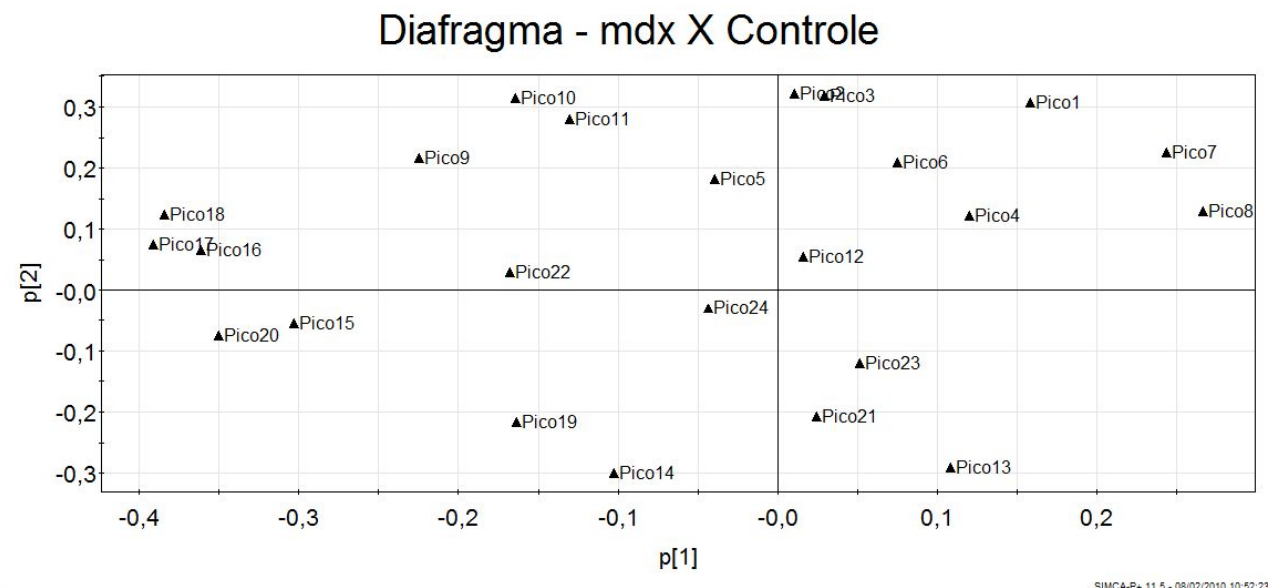

Figura 5.14: Gráfico de loading mostrando as contribuições de cada uma das variáveis originais na construção das componentes principais PC1 e PC2 (p1 e p2) na comparação entre camundongos $m d x$ e de controle para as amostras de diafragma.

mundongos de controle com mesma idade, para as amostras de quadríceps, as quatro primeiras componentes principais puderam representar 70,9\% da informação inicial. Entre estas, a primeira e a segunda componentes principais apresentaram a melhor distinção entre os dois grupos de animais. No gráfico de score de PC1XPC2 foi possível identificar um agrupamento dos camundongos $m d x$ em torno do segundo quadrante, enquanto os camundongos de controle com 3 meses se agruparam no quarto quadrante (Figura 5.15). No gráfico de loading observou-se que os camundongos $m d x$ com 3 meses de idade apresentaram valores elevados para as integrais dos picos 7 e 9, referentes ao glutamato, e dos pi$\cos 8$ e 11, referentes à glutamina, enquanto apresentaram valores reduzidos para as integrais dos picos 12 (carnosina / metionina), 13 (creatina / carnosina), 19 (creatina), 21 (AMP/ATP), 22 (carnosina), 23 (AMP/ADP/ATP) e 24 (AMP/ADP/ATP).

Para a comparação entre as amostras de diafragma dos camundongos doentes e sadios com 3 meses de idade, foi possível condensar $67,2 \%$ da informação nas quatro primeiras componentes principais. Apenas a terceira componente principal pode diferenciar de maneira apreciável os dois grupos de animais. No gráfico de score os camundongos $m d x$ com 3 meses de idade se agruparam em torno do primeiro quadrante, enquanto os camundongos de con- 


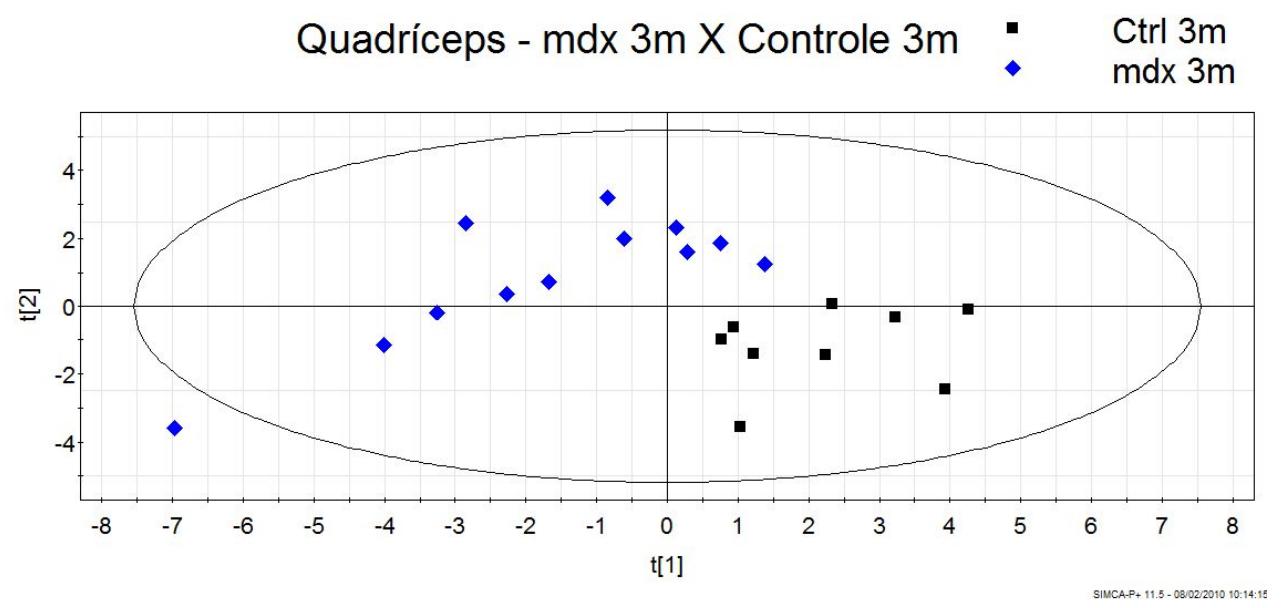

Figura 5.15: Gráfico de score para as componentes principais PC1 e PC2 na comparação entre camundongos $m d x$ com 3 meses e camundongos de controle de mesma idade para as amostras de quadríceps.

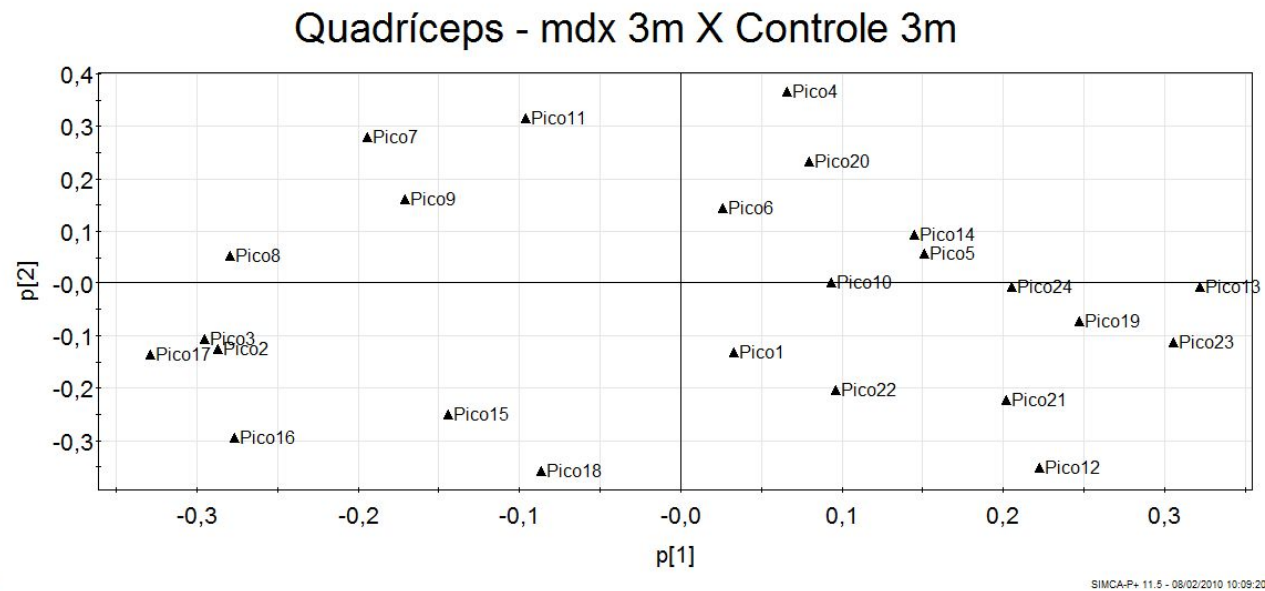

Figura 5.16: Gráfico de loading mostrando as contribuições de cada uma das variáveis originais na construção das componentes principais PC2 e PC3 (p2 e p3) na comparação entre camundongos $m d x$ com 3 meses e camundongos de controle com a mesma idade para as amostras de quadríceps. 
trole de mesma idade se agruparam em torno do terceiro quadrante (Figura 5.17). No gráfico de loading observou-se que os camundongos $\boldsymbol{m d x}$ apresentam aumento nos valores das integrais dos picos 2 ( $\beta$-hidroxibutirato), 3 (isoleucina), 6 (acetato), 9 (glutamato), 10 (glutamato / succinato), 12 (carnosina / metionina), 17 (isoleucina / glicose) e 18 (glutamato / glicose / glicerol / metionina / glutamina / alanina). Nas amostras de camundongos $m d x$ de 3 meses observou-se redução nos picos 4(lactato), 13 (creatina / carnosina), 14 (taurina / carnitina / carnosina), 19 (creatina), 21 (AMP/ATP) e 23 (AMP/ADP/ATP) (Figura 5.18).

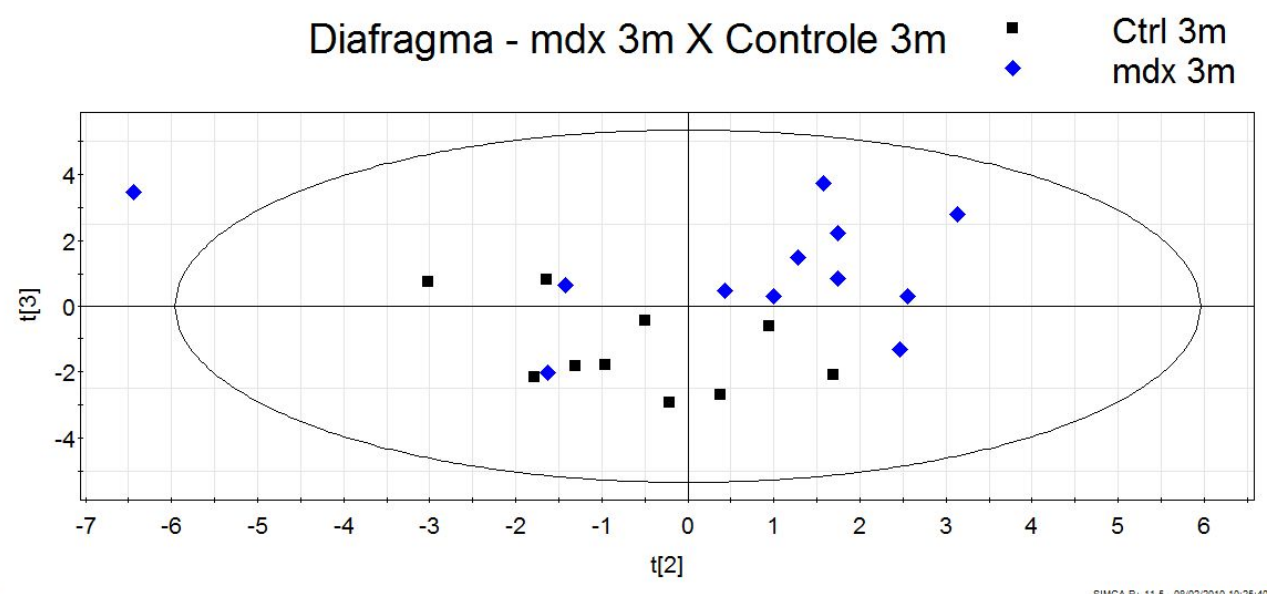

Figura 5.17: Gráfico de score para as componentes principais PC2 e PC3 na comparação entre camundongos $m d x$ e de controle com 3 meses de idade para as amostras de diafragma.

Para as amostras de quadríceps, na comparação entre os camundongos $m d x$ com 6 meses de idade e os camundongos de controle de mesma idade, foi possível concentrar $64 \%$ da informação inicial em quatro componentes principais. A primeira e a segunda componentes principais foram as que melhor diferenciaram os dois grupos de animais. No gráfico de score destas componentes foi possível observar separação dos dois grupos de animais, sendo que os camundongos $m d x$ com 6 meses de idade se agruparam no hemisfério superior, em torno do primeiro quadrante, e os camundongos de controle de mesma idade se agruparam no quarto quadrante (Figura 5.19). No gráfico de loading, foi possível observar que os camundongos $m d x$ de 6 meses de idade apresentam elevação nos valores das integrais dos picos 4 (lactato), 9 (glutamato), 10 (glu- 


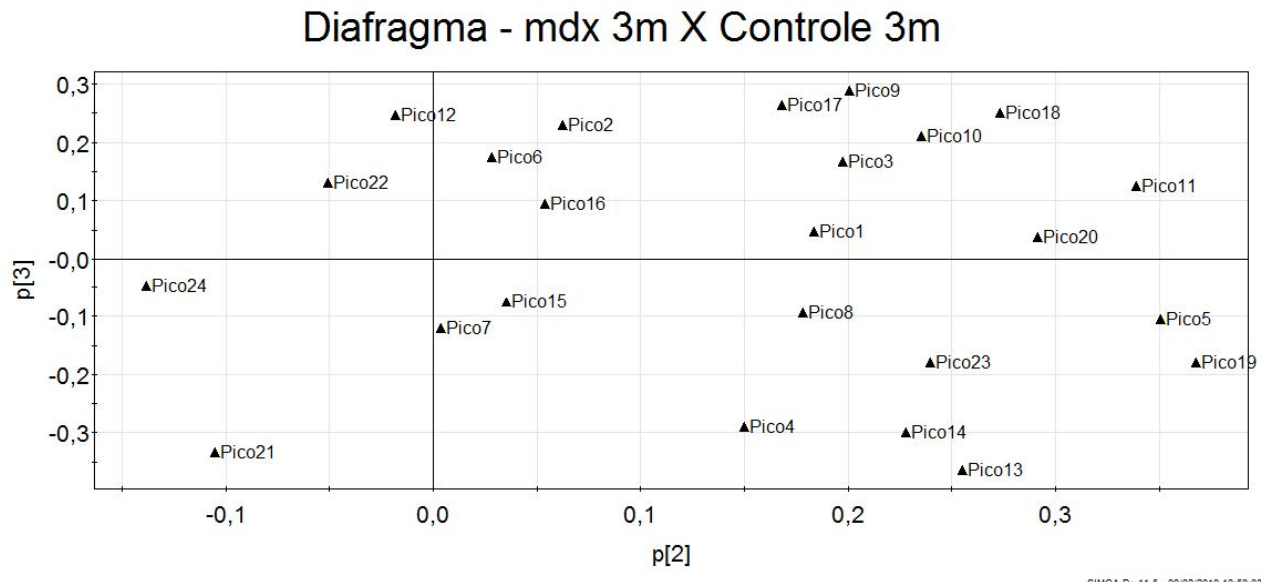

Figura 5.18: Gráfico de loading mostrando as contribuições de cada uma das variáveis originais na construção das componentes principais PC2 e PC3 (p2 e p3) na comparação entre camundongos $m d x$ com 3 meses e camundongos de controle com a mesma idade para as amostras de diafragma.

tamato / succinato), 11 (glutamina), 19 (creatina), 20 (lactato/ $\beta$ hidroxibutirato) e 24 (AMP/ADP/ATP) em comparação aos camundongos de controle de mesma idade. Os camundongos $m \boldsymbol{d x}$ de 6 meses apresentaram redução nos valores das integrais dos picos 1 (lipídios / isoleucina), 12 (carnosina / metionina), 15 (glicina), 18 (glutamato / glicose / glicerol / metionina / glutamina / alanina), 21 (AMP/ATP), 22 (carnosina) e 23 (AMP/ADP/ATP) (Figura 5.20).

Para as amostras de diafragma, na comparação entre camundongos $\boldsymbol{m d x}$ com 6 meses e os camundongos de controle de mesma idade, foi possível concentrar $65,3 \%$ da informação inicial em quatro componentes principais. A primeira e a segunda componentes principais foram as que melhor diferenciaram os dois grupos de animais.No gráfico de score foi possível observar boa separação entre os grupos, sendo que os camundongos $m d x$ se agruparam em torno do segundo quadrante e os camundongos de controle se agruparam em torno do quarto quadrante (Figura 5.21). No gráfico de loading observa-se que os camundongos mdx com 6 meses de idade apresentam aumento nos valores das integrais dos picos 5 (alanina), 6 (acetato), 9 (glutamato), 10 (glutamato / succinato), 15 (glicina), 16 (glicerol), 17 (isoleucina / glicose), 18 (glutamato / glicose / glicerol / metionina / glutamina / alanina), 20 (lactato 


\section{Quadríceps - mdx 6m X Controle 6m $\quad \Delta \quad$ Ctrl 6m $\mathrm{mdx} 6 \mathrm{~m}$}

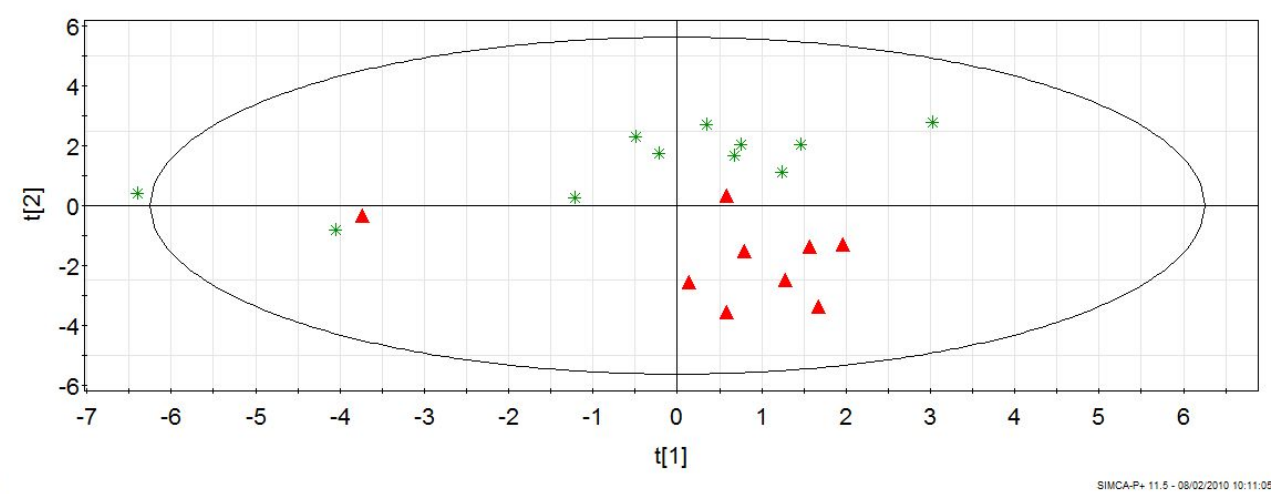

Figura 5.19: Gráfico de score para as componentes principais PC1 e PC2 na comparação entre camundongos $m d x$ e de controle com 6 meses de idade para as amostras de quadríceps.

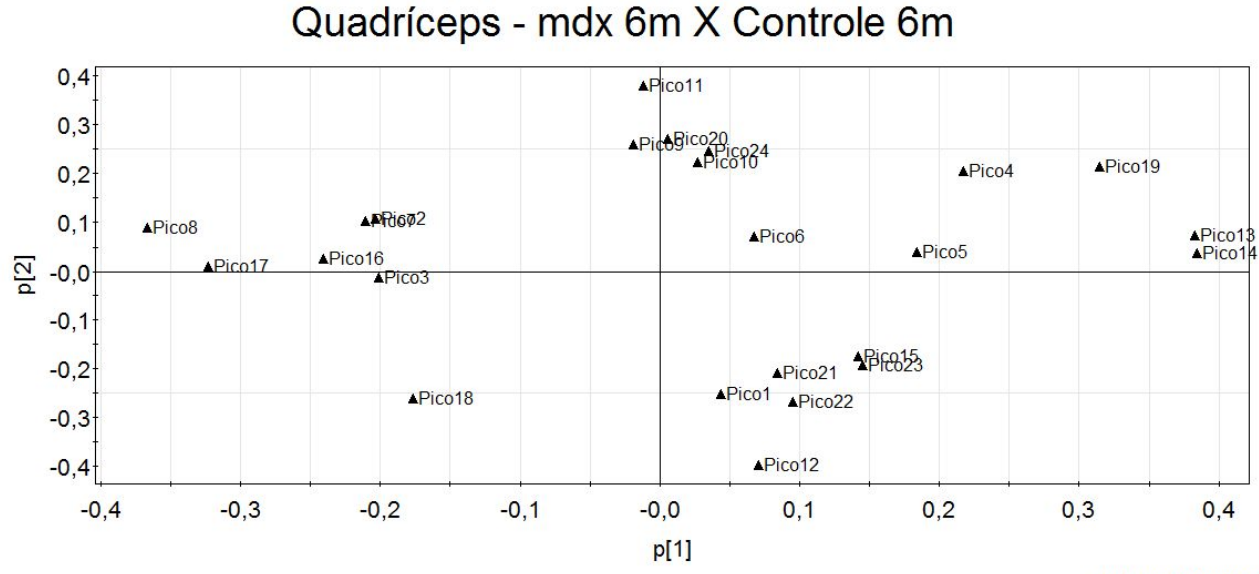

Figura 5.20: Gráfico de loading mostrando as contribuições de cada uma das variáveis originais na construção das componentes principais PC1 e PC2 (p1 e p2) na comparação entre camundongos $m d x$ com 6 meses e camundongos de controle com a mesma idade para as amostras de quadríceps. 
/ $\beta$-hidroxibutirato) e 22 (carnosina) em relação aos camundongos de controle de mesma idade. Os camundongos $\boldsymbol{m d x}$ apresentaram redução nos valores das integrais dos picos 8 (glutamina / metionina), 12 (carnosina / metionina), 13 (creatina / carnosina) e 23 (AMP/ADP/ATP).

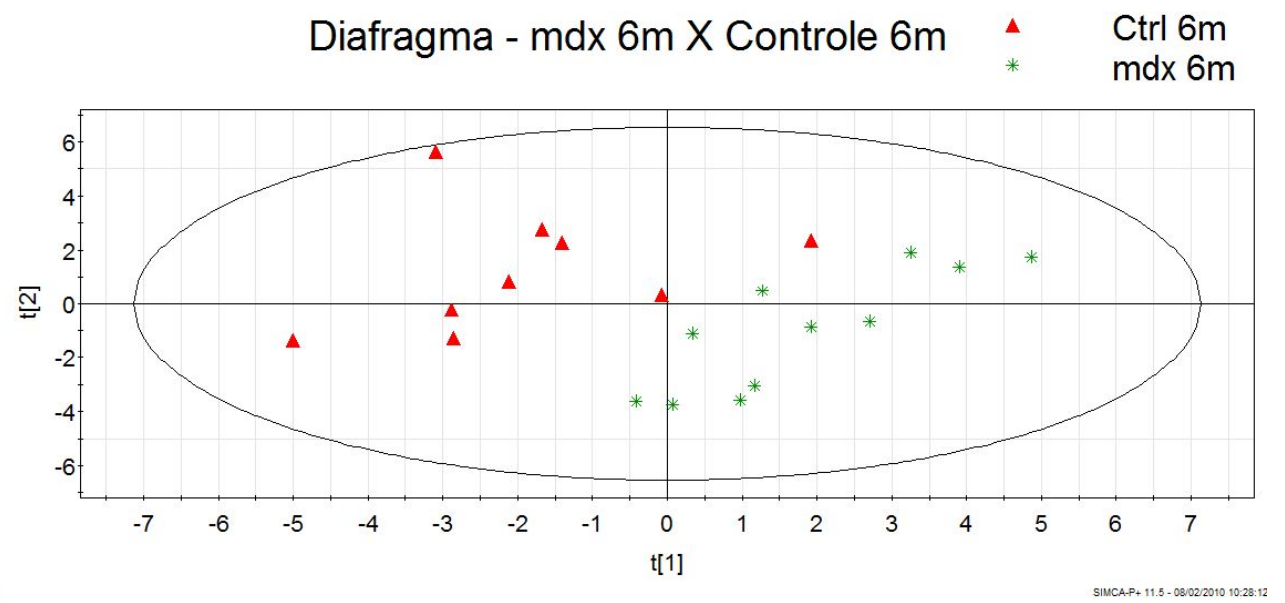

Figura 5.21: Gráfico de score para as componentes principais PC1 e PC2 na comparação entre camundongos $m d x$ e de controle com 6 meses de idade para as amostras de diafragma.

O método PCA se mostrou capaz de diferenciar camundongos $\boldsymbol{m} \boldsymbol{d x}$ dos camundongos de controle em diferentes idades. Adicionalmente, foram comparados os camundongos de controle com idades diferentes, a fim de se acompanhar possíveis alterações metabólicas ocasionadas pelo avanço da idade, e os camundongos $m d x$ com idades diferentes, a fim de se observar possíveis diferenças na evolução da distrofia em comparação às alterações observadas com o envelhecimento normal. Na comparação entre os camundongos de controle de idades diferentes, e $65,4 \%$ da informação inicial pode ser representada em quatro componentes principais. O gráfico de scores da primeira componente principal (PC1) contra a segunda (PC2) mostrou distinção entre os camundongos de controle com idades diferentes, agrupando os camundongos com 3 meses de idade no terceiro quadrante, enquanto os camundongos com 6 meses de idade se agruparam no primeiro quadrante (Figura 5.23).

No gráfico de loading correspondente observa-se que os camundongos de controle com 3 meses de idade apresentam aumento nos valores das integrais dos picos 4 (lactato), 5 (alanina), 10 (glu- 


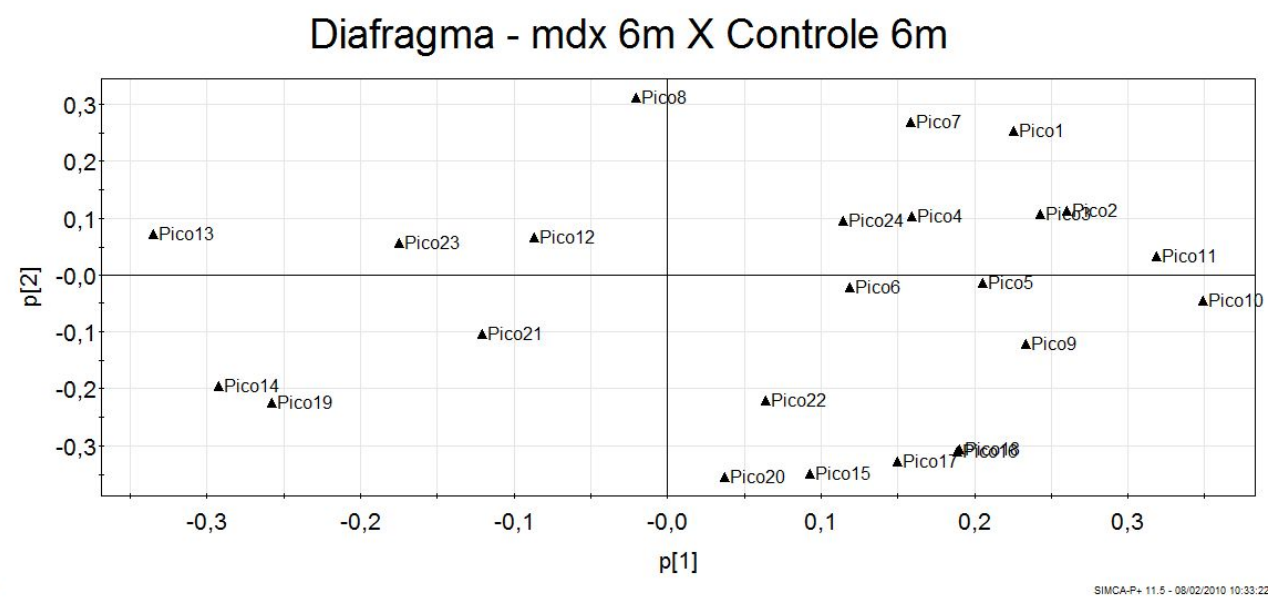

Figura 5.22: Gráfico de loading mostrando as contribuições de cada uma das variáveis originais na construção das componentes principais PC1 e PC2 (p1 e p2)na comparação entre amostras de diafragma de camundongos $m d x$ com 3 meses e camundongos de controle com a mesma idade.

tamato / succinato), 11 (glutamina), 13 (creatina / carnosina), 14 (taurina / carnitina / carnosina), 15 (glicina), 16 (glicerol), 19 (creatina) e 24 (AMP/ADP/ATP). Já os camundongos de controle com 6 meses de idade apresentaram aumento nos valores das integrais dos picos 1 (lipídios / isoleucina), 7 (glutamato), 8 (glutamina / metionina), 9 (glutamato), 17 (glicose / isoleucina), 18 (glutamato / glicose / glicerol / metionina / glutamina / alanina) e 22 (carnosina) (Figura 5.24).

Para as amostras de diafragma, na comparação entre camundongos de controle com idades diferentes $70,9 \%$ da informação inicial estava contida nas quatro primeiras componentes principais.Em nenhum dos gráficos de score analisados foi possível caracterizar uma separação entre os grupos de animais sadios com 3 e 6 meses de idade. O gráfico de score das duas primeiras componentes está ilustrado na Figura 5.25.

$\mathrm{Na}$ comparação entre camundongos $\boldsymbol{m d x}$ de idades diferentes, para as amostras de quadríceps, $69,1 \%$ da informação original pode ser explicada com apenas quatro componentes principais.Foi possível observar uma distinção entre os dois grupos de animais doentes no gráfico de score das duas primeiras componentes principais (Figura 5.26), e através do gráfico de loading observou-se que os camundongos $m d x$ com 6 meses de idade apresentam aumento nos 


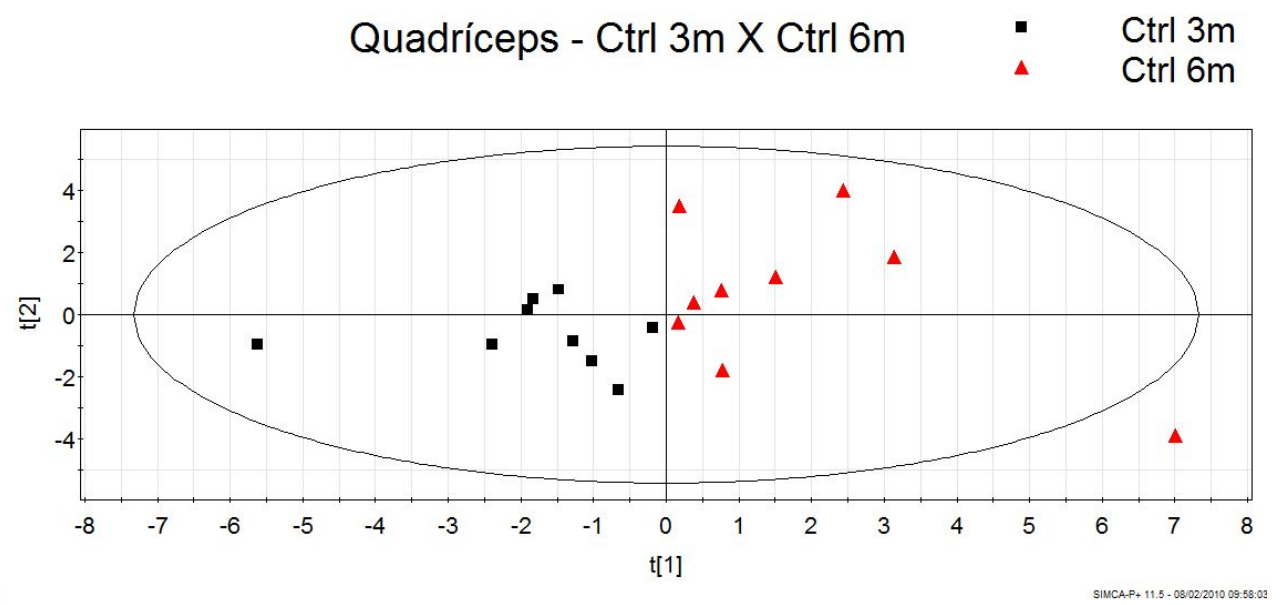

Figura 5.23: Gráfico de score para as componentes principais PC1 e PC2 na comparação entre camundongos de controle com 3 e 6 meses para as amostras de quadríceps.

\section{Quadríceps - Controle 3m X Controle 6m}

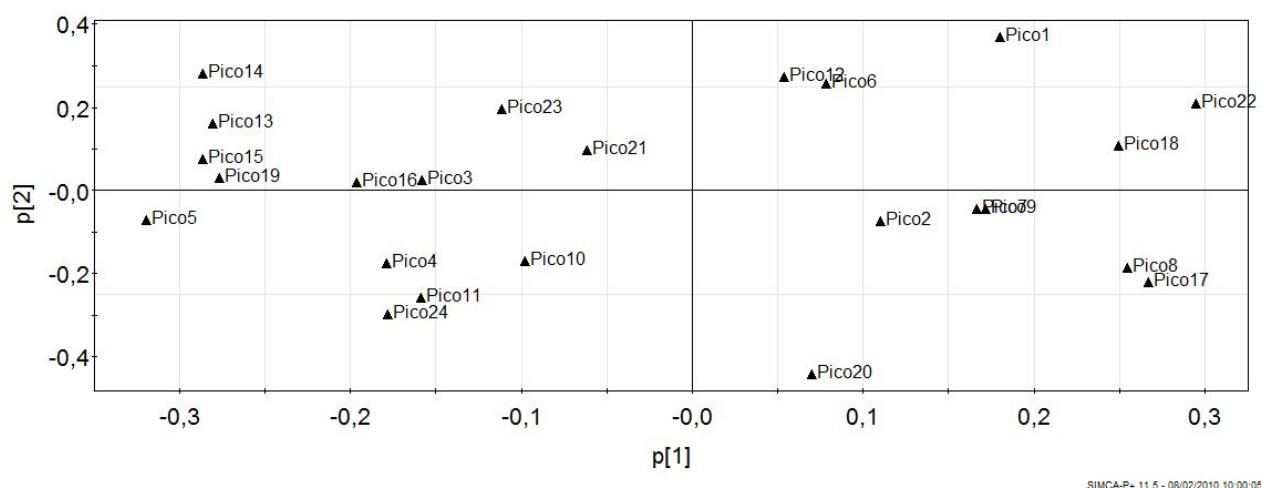

Figura 5.24: Gráfico de loading mostrando as contribuições de cada uma das variáveis originais na construção das componentes principais PC1 e PC2 (p1 e p2) na comparação entre camundongos de controle com 3 e 6 meses de idade para as amostras de quadríceps. 


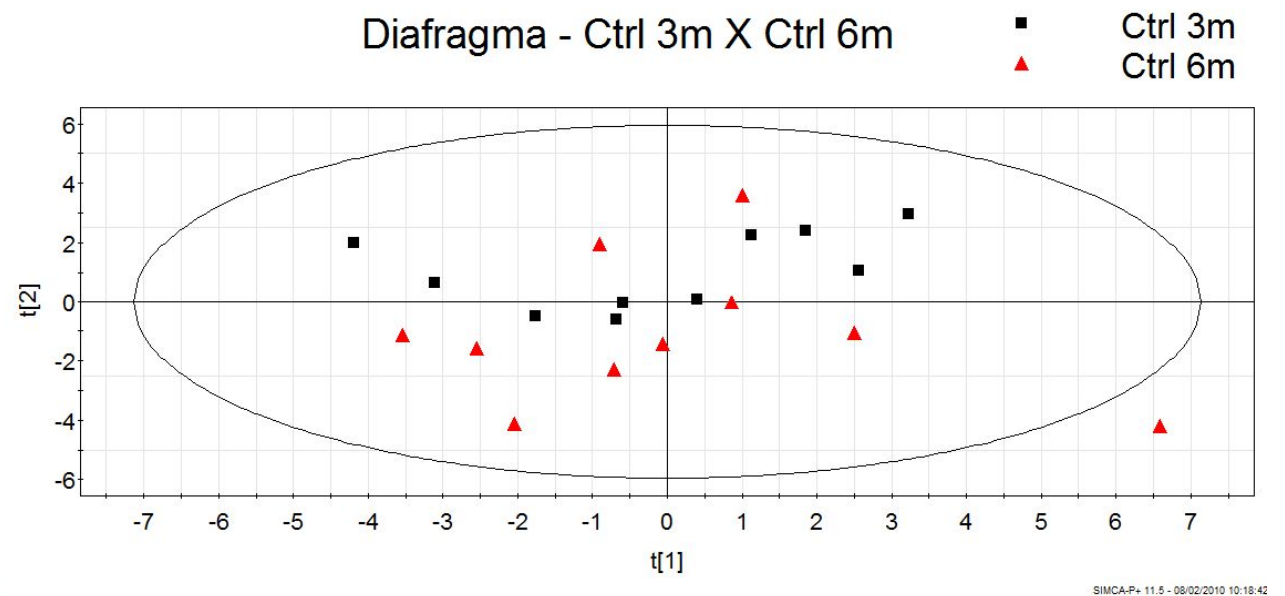

Figura 5.25: Gráfico de score para as componentes principais PC1 e PC2 na comparação entre camundongos de controle com 3 e 6 meses de idade para as amostras de diafragma.

valores das integrais dos picos 1 (lipídios / isoleucina), 7 (glutamato), 8 (glutamina/metionina), 9 (glutamato), 10 (glutamato / succinato), 12 (carnosina / metionina), 18 (glutamato / glicose / glicerol / metionina / glutamina / alanina) e 21 (AMP/ATP) (Figura 5.27).

Para as amostras de diafragma, na comparação entre camundongos $\boldsymbol{m d x}$ de diferentes idades, $69,7 \%$ da informação inicial pode ser descrita em apenas quatro componentes principais. Não foi possível observar distinção clara entre os camundongos $\boldsymbol{m d x}$ de 3 e de 6 meses nos gráficos de score (Figura 5.28). Tal resultado era esperado, uma vez que aos 3 meses de idade o diafragma dos camundongos $m d x$ apresenta um grau de afecção semelhante ao observado nos camundongos $m d x$ com 6 meses de idade. 


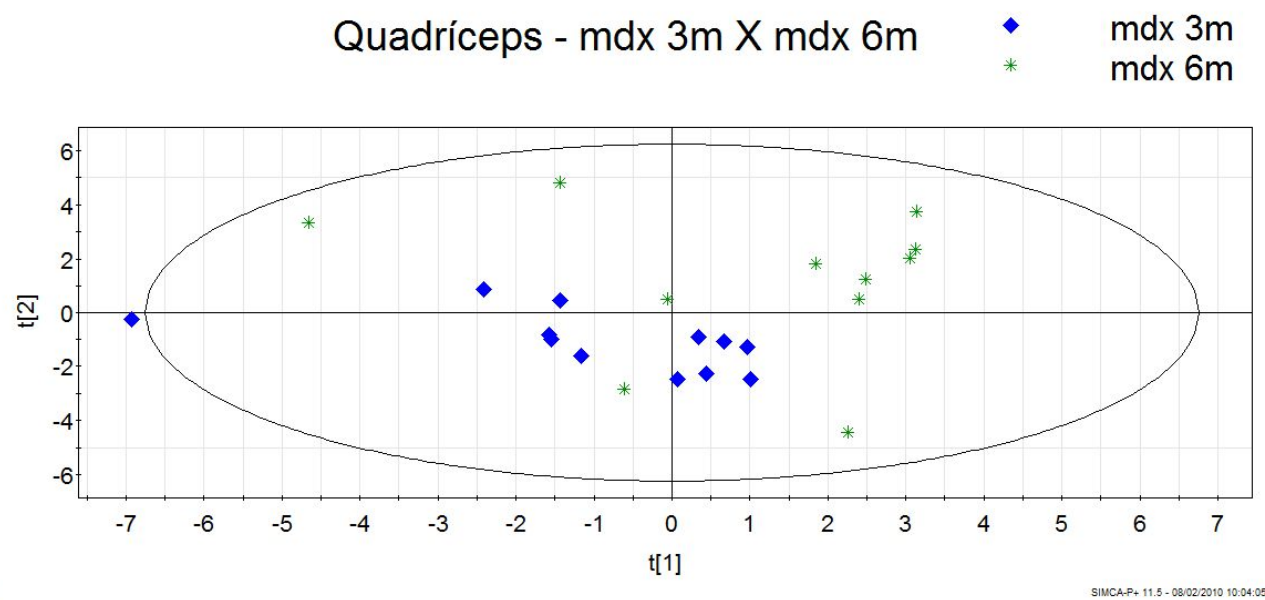

Figura 5.26: Gráfico de score para as componentes principais PC1 e PC2 na comparação entre camundongos $m d x$ com 3 e 6 meses de idade para as amostras de quadríceps.

\section{Quadríceps - mdx 3m X mdx 6m}

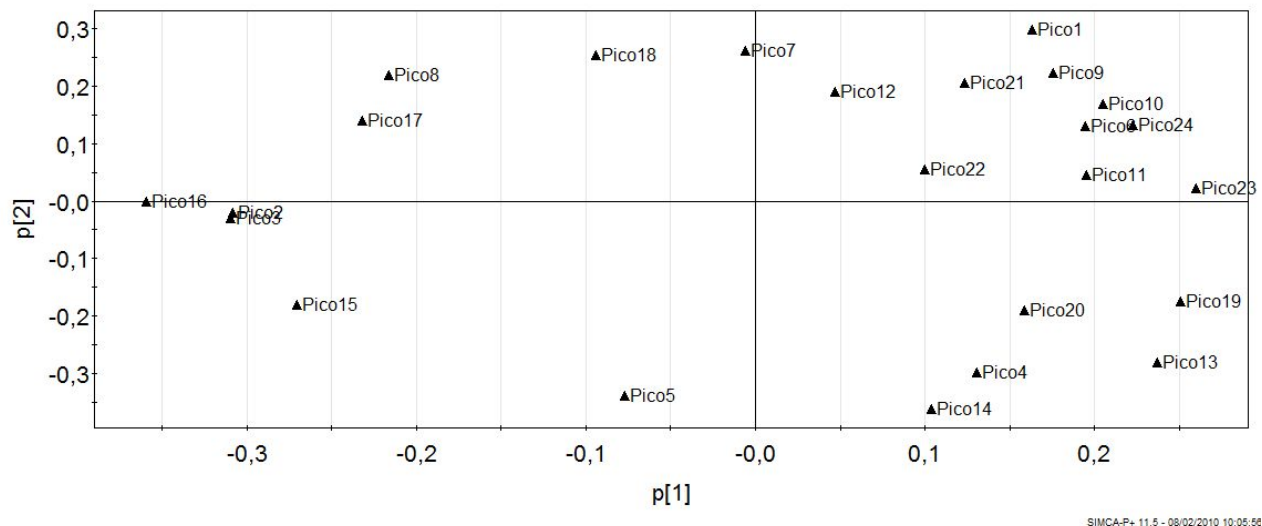

Figura 5.27: Gráfico de loading mostrando as contribuições de cada uma das variáveis originais na construção das componentes principais PC1 e PC2 (p1 e p2) na comparação entre camundongos $m d x$ com 3 e 6 meses de idade para as amostras de quadríceps. 


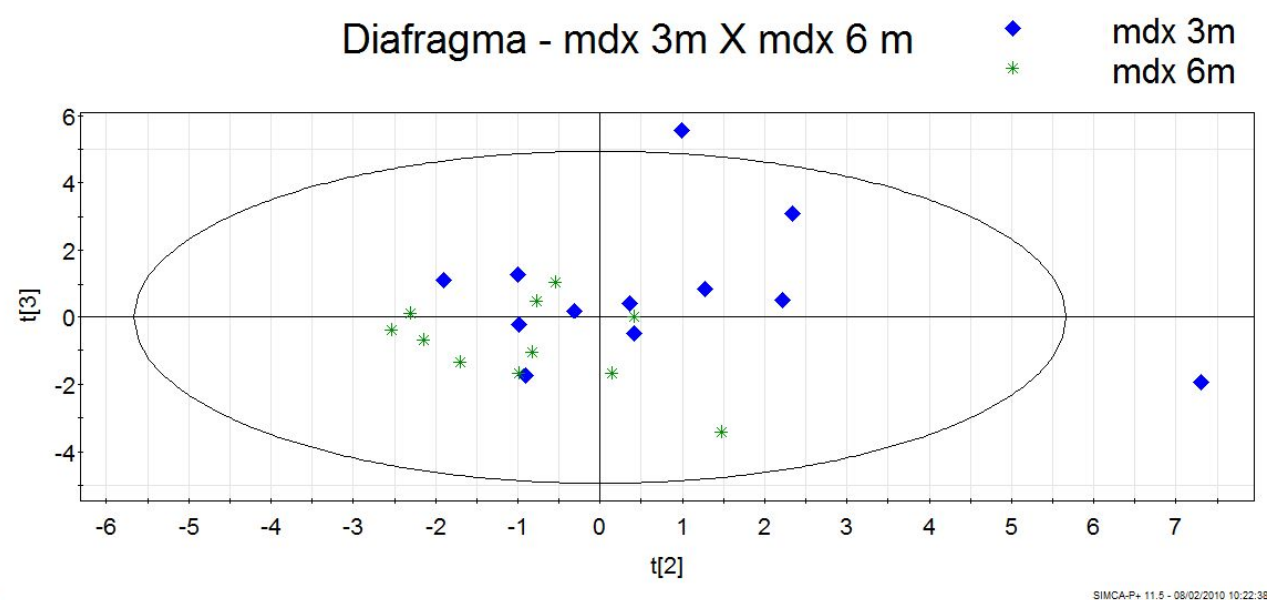

Figura 5.28: Gráfico de score para as componentes principais PC2 e PC3 na comparação entre camundongos $m d x$ com 3 e 6 meses de idade para as amostras de diafragma.

\subsubsection{Resultados Gerais}

Os resultados da comparação direta entre os valores das integrais dos picos e os resultados obtidos através do método PCA na comparação entre camundongos $m d x$ e de controle em diferentes idades encontram-se resumidos na Tabela 5.2. Os resultados para as comparações entre camundongos de mesmas linhagens de idades diferentes encontram-se na Tabela 5.3. 


\begin{tabular}{|c|c|c|}
\hline & Quadríceps & Diafragma \\
\hline$m d x$ X Controle & 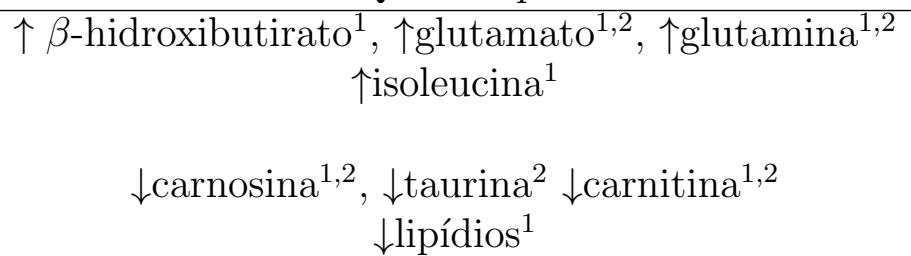 & $\begin{array}{c}\text { }_{\text {glutamato }}^{1,2}, \uparrow \text { glutamina }^{1,2}, \uparrow \text { succinato }^{1,2} \\
\uparrow \text { glicina }^{1}, \uparrow \text { glicerol }^{1,2} \\
\downarrow \text { creatina }^{1,2}, \downarrow \text { carnosina }^{1,2}\end{array}$ \\
\hline$m d x 3 \mathrm{~m} X$ Controle $3 \mathrm{~m}$ & $\begin{array}{c}\uparrow \beta \text {-hidroxibutirato }{ }^{1}, \uparrow \text { glutamato }^{1,2}, \uparrow \text { glutamina }^{1,2} \\
\uparrow \text { isoleucina }^{1} \\
\downarrow \text { creatina }^{1,2}, \downarrow \text { carnosina }^{1,2}, \downarrow \text { metionina }^{1,2}\end{array}$ & 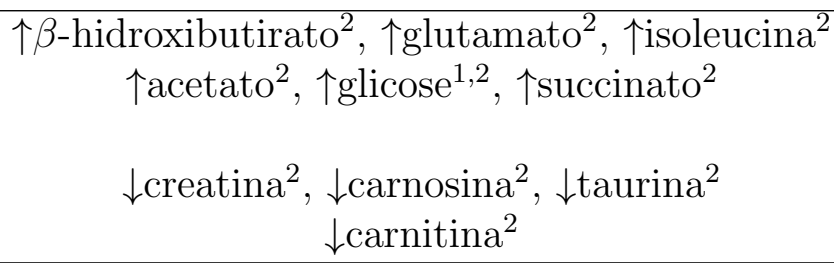 \\
\hline$m d x 6 \mathrm{~m}$ X Controle $6 \mathrm{~m}$ & $\begin{array}{c}\uparrow \beta \text {-hidroxibutirato }{ }^{1,2}, \uparrow \text { glutamato }^{2}, \uparrow \text { glutamina } \\
\uparrow \text { creatina }^{2}, \uparrow \text { succinato }^{2} \\
\downarrow_{\text {carnosina }^{1,2},}, \downarrow \text { metionina }^{1,2}, \downarrow \text { glicina }^{2} \\
\downarrow \text { lipídios }^{1,2}\end{array}$ & 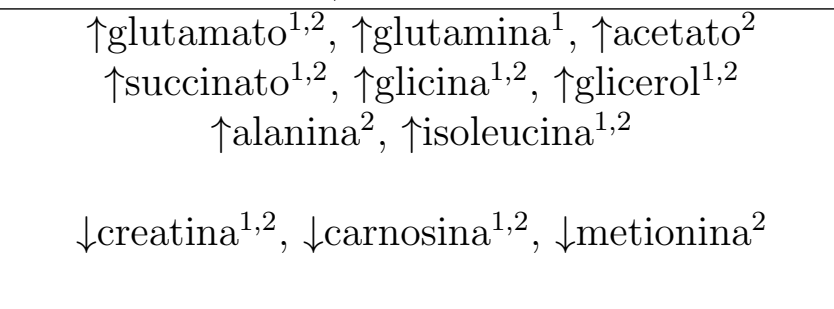 \\
\hline
\end{tabular}

Tabela 5.2: Metabólitos alterados na comparação entre todos os camundongos $m d x$ e os camundongos de controle, e entre os camundongos de linhagens diferentes com 3 ou 6 meses de idade. $\uparrow$ refere-se aos metabólitos observados aumentados nos camundongos $m d x$ e $\downarrow$ refere-se aos metabólitos observados em concentração reduzida nos animais doentes. ${ }^{1}$ refere-se a alterações observadas por comparação direta entre as integrais dos metabólitos e ${ }^{2}$ refere-se a alterações observadas através do método PCA. 


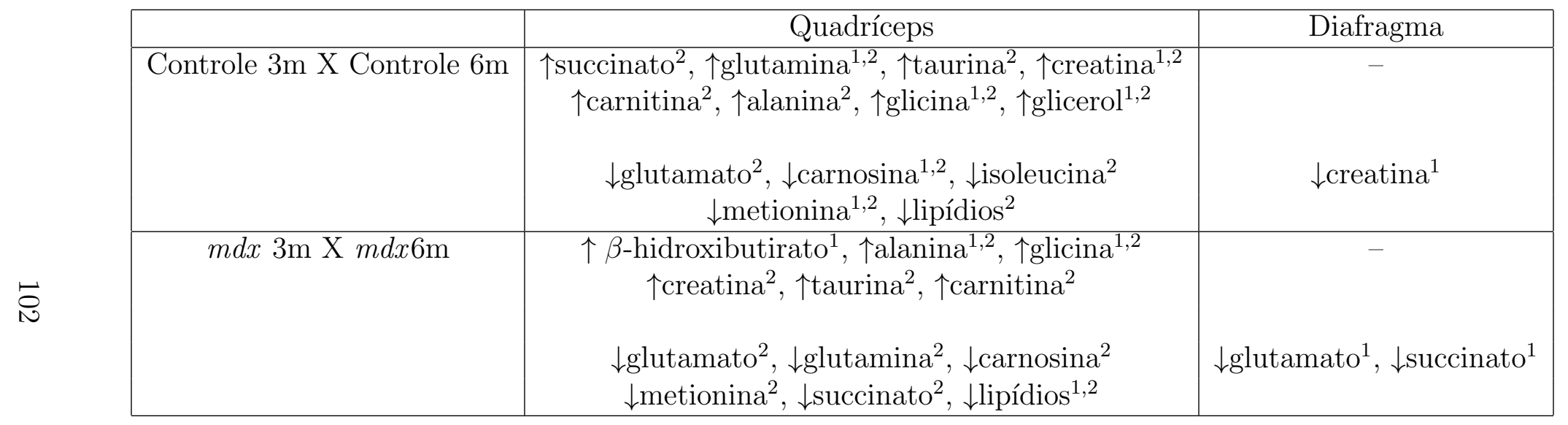

Tabela 5.3: Metabólitos alterados na comparação entre camundongos de controle de 3 meses e camundongos de controle de 6 meses e entre camundongos $m d x$ com 3 e 6 meses de idade. $\uparrow$ refere-se aos metabólitos observados aumentados nos camundongos $m d x$ ou de controle com 3 meses $\downarrow$ refere-se aos metabólitos observados em concentração reduzida nos animais desta idade. ${ }^{1}$ refere-se a alterações observadas por comparação direta entre as integrais dos metabólitos e ${ }^{2}$ refere-se a alterações observadas através do método PCA. 


\subsubsection{Análise Histológica}

A análise histológica permitiu a visualização do padrão distrófico já conhecido para os camundongos $\boldsymbol{m d x}$. Foram observados focos de degeneração/regeneração, fibras centronucleadas, variação no calibre das fibras e infiltração por tecido conjuntivo tanto nas amostras de quadríceps como nas amostras de diafragma dos camundongos $m d x$, enquanto os camundongos de controle apresentaram o padrão de músculo sadio, com pouca variação no diâmetro das fibras musculares, núcleos periféricos e pouco ou nenhum preenchimento por tecido conjuntivo (Figura 5.29). 

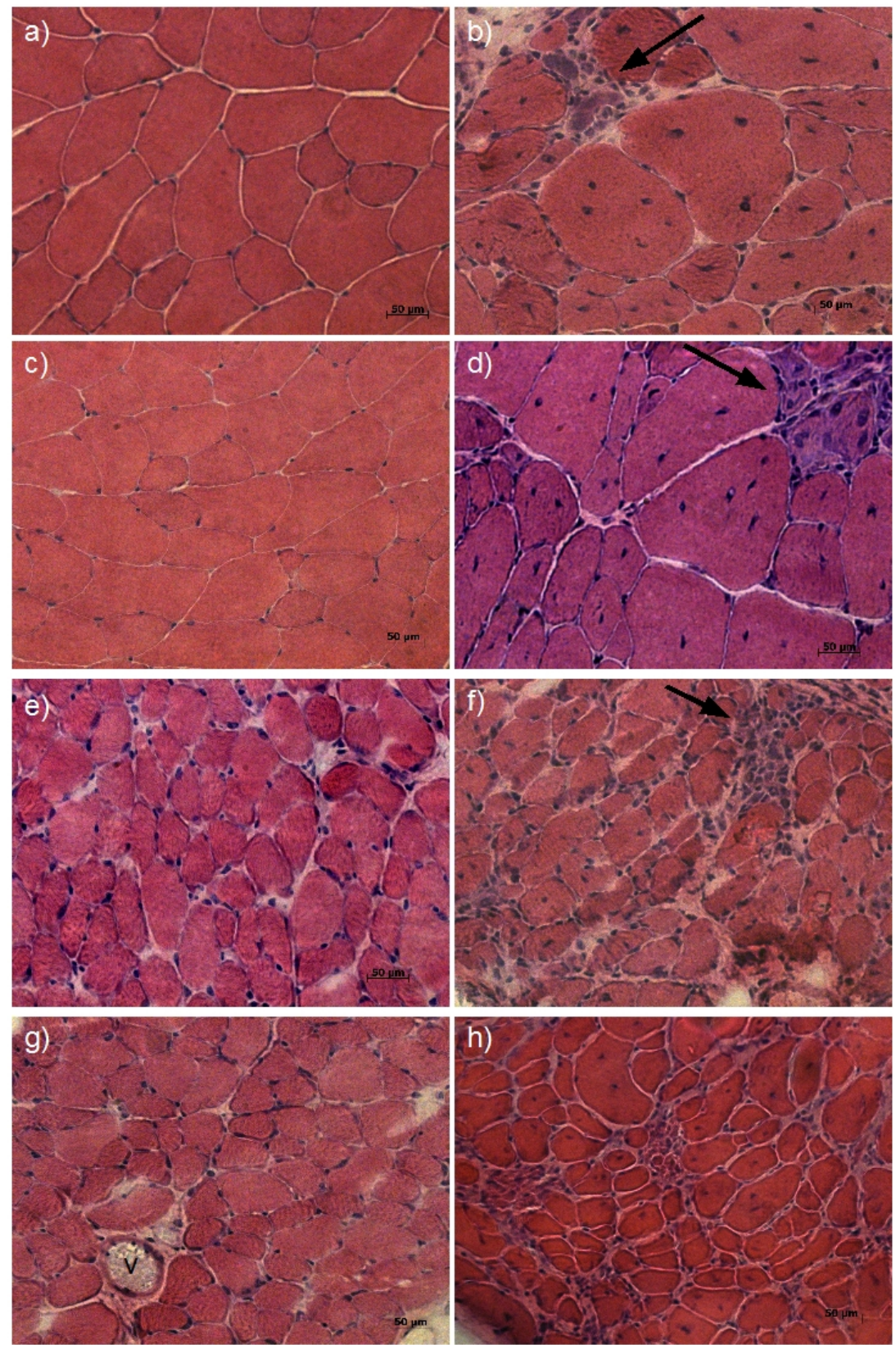

Figura 5.29: Aspecto histopatológico dos músculos quadríceps e diafragma de camundongos sadios e distróficos com idades diferentes, em aumento de 400 vezes. a) Quadríceps de camundongo sadio de 3 meses. b) Quadríceps de camundongo $m d x$ de 3 meses. c) Quadríceps de camundongo sadio de 6 meses. d) Quadríceps de camundongo $m d x$ de 6 meses. e) Diafragma de camundongo sadio de 3 meses. $f$ ) Diafragma de camundongo $m d x$ de 3 meses. g) Diafragma de camundongo sadio de 6 meses. g) Diafragma de camundongo $m d x$ de 6 meses. A setas indicam focos de degeneração e de regeneração muscular, e V indica um vaso sanguíneo. 


\section{Capítulo 6}

\section{Discussão}

Através da espectroscopia de ${ }^{1} \mathrm{H}$ RMN foi possível observar diferenças entre os camundongos doentes e de controle, inclusive quando separados por idades. Também foi possível identificar distinções entre os camundongos de controle com idades diferentes e entre camundongos $\boldsymbol{m d x}$ em estágios diferentes da doença para as amostras de quadríceps. Tais distinções foram possíveis apenas quando foram comparados os valores das integrais dos picos, uma vez que visualmente não houve diferença entre os espectros para amostras de classes diferentes.

A análise dos espectros bi-dimensionais permitiu a identificação de metabólitos com picos sobrepostos, entretanto alguns picos não puderam ser identificados com precisão. O pico 18 mostrou ser uma superposição de picos referentes a vários metabólitos, o que comprometeu a análise de alterações no mesmo. Alterações nos picos 21, 23 e 24 também se mostraram de difícil interpretação, uma vez que com os dados obtidos não é possível distinguir se os picos se referem a AMP (adenosina monofosfato), ADP (adenosina difosfato) ou ATP (adenosina trifosfato), e portanto não foi possível detectar alteração nas proporções entre estas três moléculas. A realização de experimentos de espectroscopia de ${ }^{31} \mathbf{P}$ seria de grande valor para uma melhor avaliação de alterações nestes metabólitos. Alterações nos valores dos picos correspondentes ao lactato não foram consideradas confiáveis, uma vez que após a retirada dos tecidos o metabolismo energético muda de aeróbico a anaeróbico, o que poderia provocar alterações nos níveis de lactato devido ao tempo entre a coleta do tecido e o congelamento do mesmo.

$\mathrm{Na}$ comparação entre todos os camundongos $m d x$ e os sadios, tanto para as amostras de diafragma como para as amostras de qua- 
dríceps, e nas comparações entre camundongos $m d x$ e de controle de idades diferentes, para as duas análises diferentes, observou-se consistentemente elevação dos níveis de glutamato e glutamina e redução dos níveis de carnosina nos camundongos $m d x$. A elevação nos níveis de glutamato também foi relatada por Griffin e colaboradores [10] em amostras de diafragma. O glutamato e a glutamina são dois dos vinte aminoácidos proteinogênicos existentes, e a elevação dos níveis dos mesmos poderia estar relacionada à necessidade de reposição proteica devido à atividade de regeneração muscular observada nos camundongos $m d x$. Já a redução nos níveis de carnosina nunca havia sido relatada na literatura através de espectroscopia por RMN. A carnosina é um dipeptídeo composto por alanina e histidina, com atividade antioxidante e de supressão de diferentes processos metabólicos, inclusive de processos ocorridos com o envelhecimento natural. A carnosina destaca-se como inibidora da enzima histidina descarboxilase [86], que catalisa a reação de produção de histamina a partir do aminoácido histidina. A redução dos níveis de carnosina permitiria uma maior atividade da enzima histidina descarboxilase e uma maior produção de histamina, presente em processos inflamatórios como os observados nos músculos de camundongos $\boldsymbol{m d x}$.

Na comparação entre os camundongos $m d x$ e os de controle para as amostras de quadríceps, com o método PCA, e na comparação entre amostras de diafragma de camundongos $m d x$ de 3 meses e camundongos de controle com a mesma idade foi identificada uma redução no pico relativo à taurina / carnitina nos camundongos $m d x$. Em estudo semelhante, McIntoshi e colaboradores [12] observaram através de espectroscopia de ${ }^{1} \mathrm{H}$ RMN ex vivo redução nos níveis de taurina em músculos de camundongos $m d x$ com menos de 3 semanas quando comparados a camundongos de controle de mesma idade. Entretanto, camundongos $m d x$ com idade entre 3 e 6 semanas teriam níveis maiores de taurina que os camundongos $m d x$ com menos de 3 semanas, e camundongos com mais de 6 semanas teriam níveis de taurina maiores que os camundongos de controle com a mesma idade. Camerino e colaboradores [87] observaram por HPLC (High Performance Liquid Chromatography) que camundongos $m \boldsymbol{m} \boldsymbol{d x} \operatorname{com} 6$ meses de idade apresentavam níveis de taurina menores que os camundongos de controle nos músculos dos membros, no coração e no cérebro, enquanto apresentavam níveis elevados de taurina no plasma. Assim, propôs-se que nos camundongos $m d x$ apresentariam uma alteração no transporte da 
taurina para o interior das células. Sugere-se que a taurina tenha ação osmorregulatória, ajudando a manter os níveis de $C a^{2+}$ no interior da célula e assim ajudando a manter a integridade da membrana celular, ou que atue como um possível estabilizador de grupos polares na superfície da membrana celular e de proteínas, atuando como um estabilizador de membrana. A redução nos níveis de taurina observada nos camundongos $m d x$ com 3 e 6 meses de idade pode estar relacionada a uma menor atividade de regeneração nos camundongos neste estágio da doença.

Um aumento dos valores de concentração de $\beta$-hidroxibutirato nos camundongos $\boldsymbol{m d x}$ foi observado através da comparação direta dos valores das integrais dos picos para as amostras de quadríceps. Alterações na concentração do $\beta$-hidroxibutirato, um corpo cetônico produzido na $\beta$-oxidação de lipídios, pode indicar uma predominância do metabolismo de lipídios por $\beta$-oxidação nestes animais, o que justificaria a redução na concentração de lipídios observada. $\mathrm{O}$ aumento nas concentrações de $\beta$-hidroxibutirato é compatível com dados obtidos por Griffin e colaboradores [10], que observaram um aumento deste metabólito em tecido cardíaco de camundongos $m d x$. A redução na concentração de lipídios foi observada apenas no quadríceps, que não sofre intensa substituição das fibras musculares por tecido conjuntivo ou adiposo.

Na comparação entre camundongos $m d x$ e de controle destacase ainda a diferença nos níveis de creatina, que se encontraram reduzidos em todos os camundongos distróficos nas amostras de diafragma e nas amostras de quadríceps dos camundongos mdx com 3 meses de idade. Tal resultado está de acordo com estudo feito em biópsia muscular de pacientes com DMD [14] e estudo em extratos aquosos de sóleo de camundongos $m d x$ [10]. A creatina é sintetizada principalmente no fígado e carregada para as células musculares pela corrente sanguínea. McClure e colaboradores [88] observaram que os camundongos $m d x$ poderiam produzir creatina nas células musculares em maior quantidade que os camundongos de controle devido a uma regulação positiva dos genes GAMT e AGAT, envolvidos na síntese de creatina. As células musculares dos camundongos $m \boldsymbol{m} \boldsymbol{d x}$ perdem diversos elementos do citoplasma, como a creatina e a creatinoquinase, devido ao rompimento da membrana celular observado nos animais distróficos, além de apresentarem dificuldades para captar a creatina da corrente sanguínea possivelmente devido às anomalias da membrana celular. Entretanto, a produção de creatina pela célula muscular 
dos camundongos $m \boldsymbol{m} \boldsymbol{x}$ compensaria em parte a sua perda, o que justifica o fato de os camundongos $m d x$ apresentarem uma redução menor nos níveis de creatina quando comparados aos pacientes com DMD, que chegam a apresentar até $20 \%$ dos níveis de creatina observados em controles humanos [14] enquanto os camundongos $\boldsymbol{m d x}$ apresentam cerca de $80 \%$ dos níveis encontrados em camundongos de controle $[15,4,89]$. Maiores níveis de creatina compensariam o déficit energético observado em pacientes com DMD, mas não observado nos camundongos $m d x$. Manter a capacidade energética da célula muscular é essencial para o bom funcionamento da mesma, pois diversos processos essenciais, como a ação de bombas de cálcio e a manutenção dos potenciais de membrana, são dependentes de ATP. Assim, a regulação positiva da via de produção de creatina nos camundongos os ajudaria a manter a integridade das fibras musculares.

Na comparação entre as amostras de quadríceps de camundongos de controle com idades diferentes foram identificadas diversas alterações metabólicas, como a observação de que os camundongos mais jovens apresentavam elevação nos níveis dos aminoácidos alanina, glutamina e glicina, de creatina e de glicerol para os dois métodos de análise (comparação direta das integrais dos picos e PCA), além de elevação nos níveis de lactato e taurina visualizada com o método PCA. Já os camundongos de controle com 6 meses de idade apresentaram elevação nos níveis de carnosina e metionina em comparação com os camundongos de controle mais jovens, observada nos dois métodos de análise, além de elevação nos níveis de lipídios e glutamato, observadas através do método PCA nas amostras de quadríceps. Alterações semelhantes foram observadas na comparação entre camundongos $\boldsymbol{m d x}$ com idades diferentes para as amostras de quadríceps. Os camundongos $\boldsymbol{m d x}$ mais jovens apresentaram elevação nos níveis de lactato, alanina e glicina nos dois métodos de análise, além de aumento nos níveis de creatina e taurina observado com o método PCA e dos níveis de $\beta$-hidroxibutirato observada pela comparação direta entre os valores das integrais dos picos. Já as amostras de quadríceps dos camundongos $m d x$ com 6 meses de idade apresentaram elevação nos níveis de lipídios, observada em ambos os métodos de análise, além de elevação dos níveis de glutamato, metionina e carnosina quando comparados aos camundongos $m d x$ de 3 meses. Assim, as únicas diferenças encontradas entre as alterações metabólicas provocadas pelo envelhecimento nos camundongos de controle e pela 
evolução da distrofia nos camundongos $m d x$ foram a elevação de glutamina e glicerol nos animais de controle com 3 meses, que não foi observada nos camundongos $m d x$ de mesma idade, e a elevação do $\beta$-hidroxibutirato nos camundongos $m d x$ em estágio menos avançado da doença, que não foi observada nos camundongos de controle com 3 meses de idade. A glutamina, que se apresenta em maior quantidade nos camundongos $\boldsymbol{m d x}$ nas comparações com os camundongos de controle de idade correspondente, parece estar elevada constantemente, o que justificaria o fato de não haver diferenças entre os níveis de glutamina nos animais doentes com idades diferentes. A glutamina tem função proteinogênica e gliconeogênica, e uma maior quantidade deste aminoácido nos músculos de camundongos $m d x$ os ajudaria no processo de regeneração muscular além de ser uma forma alternativa de suprimento energético. O glicerol é um componente de triglicerídeos e fosfolipídeos, enquanto o $\beta$-hidroxibutirato é um corpo cetônico, formado com a oxidação de ácidos graxos. As diferenças observadas com a evolução da doença nos camundongos $m d x$ ou com o envelhecimento natural nestes dois metabólitos podem indicar a ocorrência de alterações no metabolismo de lipídios nos camundongos $m \boldsymbol{m d x}$.

Entre as alterações metabólicas ocorridas com a idade tanto nos camundongos $m d x$ como nos de controle destacam-se os maiores níveis de taurina observados nos camundongos mais jovens das duas linhagens para as amostras de quadríceps.Este resultado está de acordo com dados de Camerino e colaboradores [87], que observaram por HPLC redução nos níveis de taurina com o avanço da idade em ratos sadios.

A análise com o método PCA não identificou diferenças no padrão metabólico observado nos diafragmas de camundongos de controle com o avanço da idade. Nas amostras de diafragma de camundongos $m d x$ com idades diferentes foi identificado um possível aumento nos níveis de succinato. Entretanto, o método PCA não identificou alterações no padrão metabólico das amostras de diafragma dos camundongos distróficos em estágios diferentes da doença, do mesmo modo como nos camundongos de controle. Tal resultado era esperado, uma vez que aos 3 meses de idade os diafragmas dos camundongos $m d x$ apresentam um nível de afecção semelhante ao observado nos diafragmas de animais de 6 meses de idade (Figura 5.29, (f) e $(h)$ ).

Há na literatura trabalhos semelhantes a este, porém algumas falhas foram observadas nos mesmos. Neste estudo foi feita a ten- 
tativa de corrigir tais falhas. Mc Intosh e colaboradores [13], em estudo de espectroscopia de ${ }^{1} \mathrm{H}$ RMN de extratos em ácido perclórico de tibial anterior e diafragma de camundongos $m d x$ e de controle, observaram redução em todos os picos analisados nos camundongos $\boldsymbol{m d x}$ quando comparados aos camundongos de controle para as amostras de diafragma (animais com 5 semanas de idade). Tal observação pode ser atribuída a erros no tratamento dos dados, uma vez que não houve nenhum tipo de correção das intensidades observadas nos espectros com o intuito de se poder comparar amostras em diferentes concentrações. Assim, as amostras de diafragma de camundongos de controle, muito mais preservadas que as amostras de diafragma dos camundongos $m d x$, apresentariam uma maior concentração de todos os metabólitos, como foi observado. Já as amostras de tibial anterior não apresentaram grandes discrepâncias entre os camundongos distróficos e sadios, uma vez que na idade dos camundongos utilizados no estudo ( 5 semanas) este músculo não sofreu grande afecção pela doença. Sharma e colaboradores [14], em estudo de RMN em extração com ácido perclórico de biópsias de quadríceps de pacientes com DMD, também não aplicaram nenhuma correção dos espectros pela massa/quantidade de material utilizado. Neste trabalho foi observado que os pacientes apresentavam redução de substrato e produto de glicólise (lactato, glicose), aminoácidos (glutamato, glutamina e alanina), e outros metabólitos (glicerofosforilcolina, fosforilcolina, carnitina, colina, creatina e acetato). Nenhum metabólito se apresentou elevado nos pacientes com DMD, o que pode indicar que houve erro no tratamento dos dados obtidos.

Griffin e colaboradores publicaram diversos artigos com análise de metabólitos através de métodos de análise multivariada, como PCA, de espectros de ${ }^{1} \mathrm{H}$ RMN de camundongos $m d x[10,76,73]$. Em todos os casos, os espectros eram normalizados pela área total, como um meio de se tentar compensar diferenças nas concentrações das amostras provenientes de diferenças na massa de tecido coletada ou de alterações nas proporções entre tecido muscular e tecido adiposo ou conjuntivo. Entretanto, para análise dos resultados os espectros foram seccionados, gerando cerca de 200 trechos que foram tratados como variáveis. Um número de variáveis tão grande pede que haja um número de amostras maior ou igual para que os resultados sejam confiáveis, mas foram utilizados menos de dez animais por grupo.

Neste trabalho, os espectros foram normalizados pela área total 
para correção de diferenças nas concentrações das amostras. Foram utilizadas as integrais dos picos observados nos espectros como variáveis de entrada para o PCA para que se reduzisse o número de variáveis analisadas, atingindo um número de variáveis compatível com o número de amostras estudadas. Uma vez que foram utilizadas apenas regiões com sinal, os valores das integrais dos picos foram normalizados para mesma variância. Assim, os picos com relativamente baixa intensidade seriam tratados com a mesma importância que os picos mais intensos. Tanto o método PCA como a comparação direta dos valores das integrais dos picos se mostraram capazes de diferenciar camundongos doentes e controles com idades diferentes, além de permitirem a observação de diferenças provenientes do avanço da doença nas amostras de quadríceps de camundongos $\boldsymbol{m d x}$ e provenientes do envelhecimento normal nas amostras de quadríceps de camundongos de controle. As diferenças observadas não são diretamente provocadas pela ausência de distrofina, mas sim alterações secundárias de várias vias metabólicas provocadas possivelmente por alterações na membrana celular e pelo influxo de cálcio nas fibras musculares. 


\section{Capítulo 7}

\section{Conclusões e Perspectivas}

Neste trabalho foram adquiridos espectros por $\mathrm{RMN}$ de ${ }^{1} \mathrm{H}$ de extratos aquosos de quadríceps e diafragma de camundongos $m d x$, modelos para a Distrofia Muscular Duchenne, com 3 e 6 meses de idade. Foram selecionados os picos observados nos espectros e as respectivas integrais foram calculadas. Este trabalho permitiu concluir que o uso da espectroscopia por RMN de ${ }^{1} \mathrm{H}$ em extratos de músculo de camundongos $m d x$, associado à comparação direta das integrais dos picos observados ou ao método PCA, permitem a distinção entre amostras de diafragma e quadríceps de camundongos doentes e sadios e entre diferentes estágios de evolução da doença ou do envelhecimento normal em amostras de quadríceps. Pode-se dizer que o método PCA se mostrou bastante apropriado para a análise de diferenças metabólicas observadas em camundongos $\boldsymbol{m d x}$ e de controle, pois permite a simplificação da informação em um menor número de variáveis, além de possibilitar a identificação dos metabólitos responsáveis por possíveis diferenças.

Os aminoácidos glutamato e glutamina se mostraram consistentemente elevados nos camundongos $m d x$. O aumento nos níveis destes aminoácidos já foi relatado em trabalhos anteriores e pode estar relacionado à intensa atividade de regeneração muscular observada nos camundogos $\boldsymbol{m d x}$. Outras alterações metabólicas foram observadas, envolvendo alterações nos níveis de creatina, taurina e aminoácidos, e tais observações foram compatíveis com dados da literatura. Neste estudo, foram feitas correções de problemas observados em trabalhos anteriores semelhantes, como a correção dos resultados de amostras com concentrações diferentes e o uso das integrais dos picos como variáveis de entrada para o método PCA.

Adicionalmente, o dipeptídeo carnosina foi consistentemente ob- 
servado em níveis reduzidos nos camundongos distróficos, alteração ainda não descrita na literatura. A carnosina é um conhecido inibidor da enzima histidina descarboxilase, responsável pela síntese de histamina a partir de histidina. Uma vez que a histamina está intimamente relacionada ao processo inflamatório, a redução nos níveis de carnosina observada nos camundongos $m d x$ pode estar envolvida no intenso processo inflamatório observado nos músculos dos camundongos $m d x$. Novas pesquisas devem ser feitas no sentido de se caracterizar melhor tais alterações nos níveis de carnosina nos músculos dos camundongos $m d x$ e seus efeitos na evolução da doença e na aplicação de possíveis terapias.

Estes resultados formam a base para futuros trabalhos envolvendo aplicação de RMN no estudo da distrofia em camundongos e em pacientes. Diferentes métodos de análise dos resultados podem ser testados, inclusive métodos de modelagem para caracterização dos estágios da doença. A aplicação da espectroscopia por RMN de ${ }^{1} \mathrm{H}$ in vivo, tanto em modelos animais como em pacientes, seria de grande valor para que se possa aplicar a técnica no acompanhamento de pacientes e de possíveis tratamentos. Adicionalmente, tem grande importância a realização de estudos envolvendo espectroscopia por $\mathrm{RMN}$ de ${ }^{31} \mathrm{P}$ in vivo na avaliação de alterações no metabolismo energético de modelos animais e pacientes distróficos. Além da espectroscopia in vivo, a espectroscopia in vitro de amostras de sangue de pacientes pode ser uma alternativa viável e menos invasiva que as atuais biópsias musculares para o acompanhamento da doença e de terapias. A RMN tem um grande potencial para aplicações em medicina, em especial aplicações no estudo de doenças neuromusculares genéticas, permitindo a caracterização de alterações metabólicas in vivo e in vitro, a visualização de imagens de alta qualidade de tecidos moles, além de recentemente estar em desenvolvimento o chamado imageamento molecular, que permite entre outras coisas o rastreamento de células tronco e o acompanhamento de terapia gênica in vivo. Adicionalmente, a RMN é um método muito seguro para aplicações em medicina por não envolver o uso de radiação ionizante. Assim, há um grande campo aberto para novas pesquisas envolvendo o estudo de distrofias musculares com o uso de RMN. 


\section{Apêndice A}

\section{Principal Component Analysis}

O método de análise chamado Análise de Componentes Principais (PCA - Principal Component Analysis) permite a redução da dimensionalidade de um conjunto de dados constituído por um grande número de variáveis relacionadas entre si, mantendo o máximo possível da variação observada no conjunto de dados original. Para isso, o método cria novas variáveis não correlacionadas, as componentes principais (PC - Principal Component), de modo que um número menor destas novas variáveis contenha a maior parte da informação contida no conjunto de dados inicial.

Suponha que $\mathrm{x}$ seja um vetor com $p$ variáveis randômicas, e que as variâncias e a estrutura de correlação e covariância entre as $p$ varáveis sejam de interesse. A menos que o número de variáveis $p$ seja pequeno ou que a estrutura de correlação e covariância seja muito simples, interpretar as $p$ variâncias e as $\frac{1}{2} p(p-1)$ correlações ou covariâncias costuma ser uma tarefa bastante complexa. Um alternativa a esta interpretação seria analisar um número de variáveis menor que $p$ que preservasse a maior parte da informação contida nas variâncias, correlações e covariâncias iniciais. O método PCA é um método eficiente para que o número de variáveis a ser analisado seja reduzido.

Apesar de o método PCA não ignorar correlações e covariâncias, ele se concentra nas variâncias do conjunto de dados inicial. O primeiro passo para a aplicação do método é observar a função linear $\mathrm{a}_{1}{ }^{\prime} \mathrm{x}$ dos elementos de $\mathrm{x}$ com máxima variância, onde $\mathrm{a}_{1}$ é um vetor de $p$ constantes, $a_{11}, a_{12}, \cdots, a_{1 p}$, e $\mathbf{a}_{1}{ }^{\prime}$ é a transposta de $\mathbf{a}_{\mathbf{1}}$, de 
modo que

$$
\mathbf{a}_{\mathbf{1}}{ }^{\prime} \mathbf{x}=a_{11} x_{1}+a_{12} x_{2}+\cdots+a_{1 p} x_{p}=\sum_{j=1}^{p} a_{1 j} x_{j} .
$$

Pode-se encontrar uma segunda função linear $\mathrm{a}_{2}{ }^{\prime} \mathrm{x}$, não correlacionada com a função $\mathrm{a}_{1} \mathrm{x}$ e com variância máxima, e assim por diante até que no $k$-ésimo passo a função $a_{k}{ }^{\prime} \mathbf{x}$ é encontrada de modo que apresente máxima variância e seja não correlacionada com $\mathbf{a}_{1}{ }^{\prime} \mathbf{x}, \mathbf{a}_{2}{ }^{\prime} \mathbf{x}, \cdots, \mathbf{a}_{\mathbf{k}-1}{ }^{\prime} \mathbf{x}$. A $k$-ésima variável encontrada será a $k$ ésima componente principal. Podem ser encontradas até $p$ componentes principais, mas se espera a maior parte da variação de $\mathrm{x}$ esteja contida nas $m$ primeiras componentes principais, e que tenhamos $m$ muito menor que $p$.

Para se encontrar as componentes principais, parte-se de $\Sigma$, a matriz de covariância de $\mathrm{x}$, o conjunto de dados inicial. Os elementos de $\Sigma, \sigma_{i j}$, em que $i \neq j$ são dados pela correlação entre $x_{i}$ e $x_{j}$, e os elementos $\sigma_{i j}$ em que $i=j$ são dados pela covariância dos $i$ elementos de $\mathrm{x}$ :

$$
\begin{aligned}
\boldsymbol{\Sigma} & =\left(\begin{array}{cccc}
\sigma_{11} & \sigma_{12} & \cdots & \sigma_{1 p} \\
\vdots & \vdots & \ddots & \vdots \\
\sigma_{p 1} & \sigma_{p 2} & \cdots & \sigma_{p p}
\end{array}\right) \\
\sigma_{i i} & =E\left(\left(x_{i}-\mu_{x_{i}}\right)^{2}\right) \\
\sigma_{i j} & =E\left(\left(x_{i}-\mu_{x_{i}}\right)\left(x_{j}-\mu x_{j}\right)\right)
\end{aligned}
$$

onde $E$ representa o valor esperado e $\mu_{x_{i}}$ é o valor médio da variável $x_{i}$.

A $k$-ésima componente principal, para $k=1,2, \cdots, p$, será tal que $z_{k}=\mathbf{a}_{\mathbf{k}}{ }^{\prime} \mathbf{x}$, onde $\mathbf{a}_{\mathbf{k}}$ é um autovetor de $\Sigma$ correspondente ao $k$-ésimo autovalor, $\lambda_{k}$. Se $\mathbf{a}_{\mathbf{k}}$ for escolhido de modo a ter comprimento unitário $\left(\mathbf{a}_{\mathbf{k}}{ }^{\prime} \mathbf{a}_{\mathbf{k}}=1\right)$, temos que $\operatorname{var}\left(z_{k}\right)=\lambda_{k}$, onde $\operatorname{var}\left(z_{k}\right)$ corresponde à variância de $z_{k}$. A primeira componente principal, $\mathbf{a}_{1} \mathrm{x}$ será tal que o vetor $\mathbf{a}_{\mathbf{1}}$ maximize $\operatorname{var}\left[\mathbf{a}_{\mathbf{1}}{ }^{\prime} \mathbf{x}\right]=\mathbf{a}_{1}^{\prime} \Sigma \mathbf{a}_{\mathbf{1}}$. Para maximizar $\mathbf{a}_{1}^{\prime} \Sigma \mathbf{a}_{\mathbf{1}}$ sujeito à normalização $\mathbf{a}_{1}^{\prime} \mathbf{a}_{1}=1$, o método padrão é usar a técnica de multiplicadores de Lagrange. Deve-se maximizar

$$
\mathbf{a}_{1}{ }^{\prime} \Sigma \mathbf{a}_{\mathbf{1}}-\lambda\left(\mathbf{a}_{\mathbf{1}}^{\prime} \mathbf{a}_{\mathbf{1}}-1\right)
$$

onde $\lambda$ é um multiplicador de Lagrange. Diferenciando A.3 com relação a $\mathrm{a}_{1}$, temos

$$
\Sigma \mathbf{a}_{1}-\lambda \mathbf{a}_{1}=0
$$


ou

$$
\left(\Sigma-\lambda \mathbf{I}_{\mathbf{p}}\right) \mathbf{a}_{\mathbf{1}}=0
$$

em que $\mathbf{I}_{\mathbf{p}}$ é a matriz identidade $p \times p$. Assim, $\lambda$ é um autovalor de $\Sigma$ e $\mathbf{a}_{1}$ é o autovetor correspondente. Para decidir quais dos $p$ autovetores deverão ser utilizados para que $\mathbf{a}_{1}^{\prime} \mathbf{x}$ tenha a maior variância possível, note que a quantidade a ser maximizada é

$$
\mathbf{a}_{1}^{\prime} \Sigma \mathbf{a}_{1}=\mathbf{a}_{1}^{\prime} \lambda \mathbf{a}_{1}=\lambda \mathbf{a}_{1}^{\prime} \mathbf{a}_{1}=\lambda
$$

o que significa que $\lambda$ deve ser o maior possível. Assim, $\mathrm{a}_{1}$ é o autovetor correspondente ao maior autovalor de $\Sigma$, e $\operatorname{var}\left(\mathbf{a}_{1}^{\prime} \mathbf{x}\right)=\mathbf{a}_{1}^{\prime} \Sigma \mathbf{a}_{1}=\lambda_{1}$ é o seu maior autovalor. A segunda componente principal, $\mathrm{a}_{2}^{\prime} \mathrm{x}$ é construída a partir do autovetor $\mathrm{a}_{2}$ e do autovalor correspondente, $\lambda_{2}$, o segundo maior autovalor de $\Sigma$, e o mesmo vale para as demais componentes principais. $\mathrm{O}$ autovetor $\mathrm{a}_{\mathrm{k}}$ é o vetor de coeficientes ou loadings para a $k$-ésima componente principal [90]. 


\section{Referências Bibliográficas}

[1] Amthor, H., Egelhof, T., McKinnell, I., Ladd, M.E., Janssen, I., Weber, J., Sinn, H., Schrenk, H.H., Forsting, M., Voit, T., Straub, V. (2004). "Albumin targeting of damaged muscle fibres in the $m d x$ mouse can be monitored by MRI.'Neuromuscular Disorders, 14(12): 791-796.

[2] Dunn, J.F., Zaim-Wadghiri, Y. (1999). "Quantitative magnetic resonance imaging of the $m d x$ mouse model of Duchenne muscular dystrophy."Muscle Nerve, 22(10): 1367-1371.

[3] Kobayashi, M., Nakamura, A., Hasegawa, D., Fujita, M., Orima, H., Takeda, S. (2009). "Evaluation of dystrophic dog pathology by fat-supressed T2-weighted imaging."Muscle Nerve, 40(5): 815-826.

[4] McIntosh, L.M., Baker, R.E., Anderson, J.E. (1998). "Magnetic resonance imaging of regenerating and dystrophic mouse muscle.'Biochemistry and Cell Biology, 76(2-3): 532541.

[5] Schneider-Gold, C., Beer, M., Köstler, H., Buchner, S., Sandstede, J., Hahn, D., Toyka, K.V. (2004). "Cardiac and skeletal muscle involvement in myotonic dystrophy type 2 (DM2): a quantitative 31P-MRS and MRI study."Muscle Nerve, 30(5): 636-644.

[6] Straub, V., Donahue, K.M., Allamand, V., Davisson, R.L., Kim, Y.R., Campbell, K.P. (2000). "Contrast agent-enhanced magnetic resonance imaging of skeletal muscle damage in animal models of muscular dystrophy."Magnetic Resonance in Medicine, 44(4): 655-659.

[7] Tardif-deGéry, S., Vilquin, J., Carlier, P., Raynaud, J.S., Wary, C., Schwartz, K., Leroy-Willig, A. (2000). "Muscular 
transverse relaxation time measurement by magnetic resonance imaging at 4 Tesla in normal and dystrophic dy/dy and $\mathrm{dy}(2 \mathrm{j}) / \mathrm{dy}(2 \mathrm{j})$ mice."Neuromuscular Disorders, 10(7): 507513.

[8] Thibaud, J.L., Monnet, A., Bertoldi, D., Barthélémy, I., Blot, S., Carlier, P.G. (2007). "Characterization of dystrophic muscle in golden retriever muscular dystrophy dogs by nuclear magnetic resonance imaging."Neuromuscular Disorders, 17: 575-584.

[9] Gillet, B., Doan, B.T., Verre-Serrie, C., Barbere, B., Berenger, G., Morin, S., Koenig, J., Peres, M., Sebille, A., Beloeil, J.C. (1993). "In vivo $2 \mathrm{D} 1 \mathrm{H}$ NMR of $m d x$ mouse muscle and myoblast cells during fusion: evidence for a characteristic signal of long chain fatty acids."Neuromuscular Disorders, 3(5-6): 433-438.

[10] Griffin, J.L., Williams, H.J., Sang, E., Clarke, K., Rae, C., Nicholson, J.K. (2001) "Metabolic Profiling of Genetic Disorders: A Multitissue 1H Nuclear Magnetic Resonance Spectroscopic and Pattern Recognition Study into Dystrophic Tissue"Analytical Biochemistry, 293: 16-21.

[11] Hsieh, T.J., Jaw, T.S., Chuang, H.Y., Jong, Y.J., Liu, C.G., Li, C.W. (2009). "Muscle metabolism in Duchenne muscular dystrophy assessed by in vivo proton magnetic resonance spectroscopy."Journal of Computer Assisted Tomography, 33(1): 150-154.

[12] McIntosh, L., Granberg, K.E., Brière, K.M., Anderson, J.E. (1998). "Nuclear magnetic resonance spectroscopy study of muscle growth, $\boldsymbol{m d x}$ dystrophy and glucocorticoid treatments: correlation with repair."NMR in Biomedicine, 11(1): 1-10.

[13] McIntosh, L.M., Garret, K.L., Rudnicki, M.A., Anderson, J.E. (1998). "Regeneration and myogenic cell proliferation correlate with taurine levels in dystrophin and MyoDdeficient muscles."The Anatomical Record, 252(2): 311-324.

[14] Sharma, U., Atri, S., Sharma, M.C., Sarkar, C., Jagannathan, N.R. (2003). "Skeletal muscle metabolism in Duchenne mus- 
cular dystrophy (DMD): an in-vitro proton NMR spectroscopy study."Magnetic Resonance Imaging, 21(2): 145-153.

[15] Dunn, J.F., Tracey, I., Radda, G.K. (1992). "A 31P-NMR study of muscle exercise metabolism in $m d x$ mice: evidence for abnormal pH regulation."Journal of the Neurological Sciences, 113(1): 108-113.

[16] Dunn, J.F., Frostick, S., Brown, G., Radda, G.K. (1991). "Energy status of cells lacking dystrophin: an in vivo/in vitro study of $m d x$ mouse skeletal muscle."Biochimica and Biophysica Acta, 1096: 115-120.

[17] Goudemant, J.F., Deconinck, N., Tinsley, J.M., Demeure, R., Robert, A., Davies, K.E., Gillis, J.M. (1998). "Expression of truncated utrophin improves pH recovery in exercising muscles of dystrophic $m d x$ mice: a $31 P$ NMR study."Neuromuscular Disorders, 8(6): 371-379.

[18] Heerschap, A., Bergman, A.H., van Vaals, J.J., Wirtz, P., Loermans, H.M., Veerkamp, J.H. (1988). "Alterations in relative phosphocreatine concentrations in preclinical mouse muscular dystrophy revealed by in vivo NMR."NMR in Biomedicine, 1(1): 27-31.

[19] Kemp, G.J., Taylor, D.J., Dunn, J.F., Frostick, S.P., Radda, G.K. (1998). "Celular energetics of dystrophic muscle."Journal of the Neurological Sciences, 116: 201-206.

[20] Youkin, D.P., Berman, P., Sladky, J., Chee, C., Bank, W., Chance, B. (1987). ${ }^{" 31} \mathrm{P}$ NMR studies in Duchenne muscular dystrophy: age related metabolic changes.'Neurology, 37: 165-169.

[21] Sharma, U., Atri, S., Sharma, M.C., Sarkar, C., Jagannathan, N.R. (2003). "Biochemical characterization of muscle tissue of limb girdle muscular dystrophy: an $1 \mathrm{H}$ and 13C NMR study."NMR in Biomedicine, 16(4): 213-223.

[22] Srivastava, N.K., Pradhan, S., Mittal, B., Gowda, G.A. (2009). "High resolution NMR based analysis of serum lipids in Duchenne muscular dystrophy patients and its possible diagnostic significance."NMR in Biomedicine, Sep 28. 
[23] Walter, G., Cordier, L., Bloy, D., Sweeney, H.L (2005). "Noninvasive monitoring of gene correction in dystrophic muscle."Magnetic Resonance in Medicine, 54(6): 1369-1376.

[24] De Graaf, R.A. (1998). "In vivo NMR Spectroscopy: Principles and Techniques", Wiley.

[25] Gil, V. M. S., Geraldes, C. F. G. C. (1987). "Ressonância Magnética Nuclear: Fundamentos, Métodos e Aplicações". Lisboa, Fundação Calouste Gulbenkian.

[26] Straughan, B.P., Walker, S. (1976). "Spectroscopy", Vol I. Londres, Chapman and Hall Ltda.

[27] Günther, H. (1994). "NMR Spectroscopy: Basic Principles, Concepts, and Applications in Chemistry", 2nd Ed., Wiley.

[28] Vainzof, M., Zatz, M. (2003). "Protein defects in neuromuscular diseases.'Brazilian Journal of Medical and Biological Research, 36(5): 543-555.

[29] Zatz, M. (2001). "Distrofias musculares Progressivas. Doenças Genéticas em pediatria."G. Carakushansky. Rio de Janeiro, Guanabara Koogan.

[30] Hawke, T. J., Garry, D. J. (2001). "Myogenic satellite cells: physiology to molecular biology."Journal of Applied Physiology, 91: 534-551.

[31] Emery, A.E. (2002). "The muscular dystrophies."Lancet, 359: 687-95.

[32] Meryon, E. (1852). "On granular and fatty degeneration of the voluntary muscles."Medical-Chirurgical Trans. (London) 35: 73 .

[33] Duchenne, G. B. (1868). "Recherches sur la paralysie musculaire pseudo-hypertrophique ou paralysie myosclerosique."Arch. Gen. Med., 11, 5, 178, 305, 421, 552.

[34] Anderson, J.L., Head, S.I., Rae, C., Morley, J.W. (2002). "Brain function in Duchenne muscular dystrophy."Brain, 125: 4-13. 
[35] Tracey, I., Dunn, J.F., Parkes, H.G., Radda, G.K. (1996). "An in vivo and in vitro ${ }^{1} \mathrm{H}$-magnetic resonance spectroscopy study of $\boldsymbol{m d x}$ mouse brain: Abnormal development or neural necrosis?"Journal of the Neurological Sciences, 141: 13-18.

[36] Hoffman, E. P., Brown Jr, R. H., Kunkel, L. M. (1987). "Dystrophin: the protein product of the Duchenne muscular dystrophy locus."Cell, 51: 919-928.

[37] Yoshida, M., Osawa, E. (1990). "Gilcoprotein complex anchoring dystrophin to sarcolemma."Journal of Biochemistry, 108: $748-752$.

[38] Nishio, H., Wada, H., Matsuo, T., Horikawa, H., Takahashi, K., Nakajima, T., Matsuo, M., Nakamura, H. (1990). "Glucose, free fatty acid and ketone body metabolism in Duchenne muscular dystrophy."Brain \& Development, 12: 390-402.

[39] Chakkalakal, J. V., Thompson, J., Parks, R. J., Jasmin, B. J. (2005). "Molecular, cellular and pharmacological therapies for Duchenne/Becher muscular dystrophies."The FASEB Journal, 19: 880-891.

[40] Hoffman, E.P. Dressman, D. (2001). "Molecular pathophysiology and targetd therapeutics for muscular dystrophy."Trends in Pharmacological Sciences, 22: 465-470.

[41] Nudel,U., Zuk, D., Einat, P., Zeelon, E., Levy, Z., Neuman, S., Yaffe, D. (1989). "Duchenne muscular dystrophy gene product is not identical in muscle and brain."Nature, 337: 76-78.

[42] Watkins, S.C., Cullen, M.J., Hoffman, E.P., Billington, L. (2000). "Plasma membrane cytoskeleton of muscle: a fine structural analysis"Microscopy Research and Technique, 48(3-4): 131-141.

[43] Ervasti, J. M., Campbell, K. P. (1993). "A role for the dystrophin-glycoprotein complex as a transmembrane linker between laminin and actin."Journal of Cell Biology, 122(4): 809-823.

[44] Campbell, K. P., Stull, J. T. (2003). "Skeletal muscle basement membrane-sarcolemma-cytoskeleton interaction minireview series."The Journal of Biolical Chemistry, 278(15): 12599-12600. 
[45] Evarsti, J.M., Campbell, K.P. (1991) "Membrane Organization of the Dystrophyn-Glicoprotein Complex."Cell 06, 11211131.

[46] Ozawa, E., Yoshida, M., et al. (1995). "Dystrophin-associated proteins in muscular dystrophy."Human Molecular Genetics, 4 Spec No: 1711-6.

[47] Straub, V., Campbell, K. P. (1997). "Muscular dystrophies and the dystrophin-glycoprotein complex."Current Opinion in Neurology, 10: 168-175.

[48] Cohn, R. D., Campbell, K. P. (2000). "Molecular basis of muscular dystrophies."Muscle Nerve, 23(10): 1456 - 1471.

[49] Rando, T. A. (2001). "The dystrophin-glycoprotein complex, cellular signaling, and the regulation of cell survival in the muscular dystrophies."Muscle Nerve, 24(12): 1575-1594.

[50] Hack, A.A., Groh, M.E., McNally, E.M. (2000). "Sarcoglicans in muscular dystrophy."Microscopy Research and Technique, 48: 167-180.

[51] Carlson, C.G. (1998). "The dystrophinopathies: an alternative to structural hypothesis."Neurobiology of Disease, 5(1): 3-15.

[52] Fong, P., Turner, P.R., Denetclaw, W.F., Steinhardt, R.A. (1990). "Increased activity of calcium channels of myotubes of Duchenne human and $m d x$ mouse origin."Science, 250: 673676.

[53] Kasper, C.E., White, T.P., Maxwell, L.C. (1990). "Running during recovery from hindlimb suspension induces transient muscle injury."Journal of Applied Physiology, 68: 533-539.

[54] Vainzof, M., Ayub-Guerrieri, D., Onofre, P.C., Martins, P.C., Lopes, V.F., Zilberztajn, D., Maia, L.S., Sell, K., Yamamoto, L.U. (2008). "Animal models for genetic neuromuscular diseases."Journal of Molecular Neurosciensce, 34(3): 241-248.

[55] Bulfield, G., Siller, W.G., Wight, P.A.L., Moore, K.J. (1984). "X chromossome-linked muscular dystrophy $(m d x)$ in the mouse."Proceedings of the National Academy of Sciences of the United States of America, 81: 1189-1182. 
[56] Sicinski, P., Geng, Y., Ryder-Cook, A.S., Barnard, E.A., Darlison, M.G., Barnard, P.J. (1989). "The molecular basis of muscular dystrophy in the $m d x$ mouse: a point mutation."Science, 244: 1578-1580.

[57] Ohlendieck, K., Campbell, K. P. (1991). "Dystrophinassociated proteins are greatly reduced in skeletal muscle from $m d x$ mice."The Journal of Cell Biology, 115(6): 168594.

[58] Moens, P., Baatsen, P.H.W., Marechal, G. (1993). "Increased susceptibillity od EDL muscles from $\boldsymbol{m d x}$ mice to damage induced by contractions with strech."Journal of Muscle Research and Cell Motility, 14: 446-451.

[59] Vilquin, J.T., Brussee, V., Asselin, I., Kinoshita, I., Gingras, M., Tremblay, J.P. (1998). "Evidence of $m d x$ mouse skeletal muscle fragility in vivo by eccentric running exercise."Muscle \& Nerve, 21: 567-576.

[60] Stedman, H.H., Sweeney, H.L., Shrager, J.B., Maguire, H.C., Panettieri, R.A., Petrof, B., Narusawa, M., Leferovich, J.M., Sladky, J.T., Kelly, A.M. (1991). "The $m d x$ mouse diaphragm reproduces the degenerative changes of Duchenne muscular dystrophy." Nature, 352: 536-539.

[61] Anderson, J.E., Garret, K., Moor, A., McIntosh, L., Penner, K. (1998). "Dystrophy and myogenesis in $m d x$ diaphragm muscle."Muscle \& Nerve, 21(9): 1153-1165

[62] Roig, M., Roma, J., Fargas, A., Munell, F. (2004). "Longitudinal pathologic study of the gastrocnemius muscle group in $m d x$ mice."Acta Neuropathologica, 107: 27-34.

[63] Pastoret, C. e Sebille, A. (1995). " $m d x$ mice show progressive weakness and muscle deterioration with age."Journal of the Neurological Sciences, 129(2): 97-105.

[64] Muller, J., Vayssiere, N., Royuela, M., Leger, M.E., Muller, A., Bacou, F., Pons, F., Hugon, G., Mornet, D. (2001). "Comparative evolution of muscular dystrophy in diaphragm, gastrocnemius and masseter muscles from old male $m \boldsymbol{d x}$ mice."Journal of Muscle Research and Cell Motility, 22: 133139. 
[65] Pastoret, C., Sebille, A. (1995). "Age related differences in regeneration of dystrophic $(m d x)$ and normal muscle in the mouse."Muscle \& Nerve, 18: 1147-1154.

[66] Quinlan, J.G., Cambier, D., Lyden, S., Dalvi, A., Upputuri, R.K., Gartside, P., Michaels, S.E., Denman, D. (1997). "Regeneration-blocked $\boldsymbol{m d x}$ muscle: in vivo model for testing treatments."Muscle \& Nerve, 20: 1016-1023.

[67] Wakeford, S., Watt, D.J., Partridge, T.A. (1991). "Xirradiation improves $\boldsymbol{m d x}$ mouse muscle as a model of myofibre loss in DMD."Muscle \& Nerve, 14: 42-50.

[68] Karpati, G., Carpenter, S., Prescott, S. (1998). "Smallcaliber skeletal muscle fibers do not suffer necrosis in $\boldsymbol{m d x}$ mouse dystrophy."Muscle \& Nerve, 11: 795-803.

[69] Weller, B., Karpati, G., Carpenter, S. (1990). "Dystrophindeficient $\boldsymbol{m d x}$ muscle fibers are preferentially vulnerable to necrosis induced by experimental lengthening contrations."Journal of the Neurological Sciences, 100: 9-13.

[70] Lodi, R., Muntoni, F., Taylor, J., Kumar, S., Sewry, C.A., Blamire, A., Stylers, P., Taylor, D.J. (1997) "Correlative MR imaging and 31P-MR spectroscopy in sarcoglycan deficient limb girdle muscular dystrophy."Neuromuscular Disorders, $7(8)$ : 505-511.

[71] Argov, Z., Banj, W.J. (1991). "Phosphorus magnetic resonance spectroscopy $\left({ }^{31} \mathbf{P} \mathrm{MRS}\right)$ in neuromuscular disorders."Annals of Neurology, 30: 90-97.

[72] Fabrizi, G.M., Lodi, R., Ettore, M.D., Malandrini, A., Cavullaro, T., Rimoldi, M., Zaniol, P., Barbiroli, B., Guazz, G. (1996). "Autossomal dominant limb girdle myopathy with ragged red fibers and cardiomyopathy. A pedigree study by in vivo ${ }^{31} \mathrm{P} \mathrm{MR}$ spectroscopy indicating a multisystem mitochondrial defect."Journal of the Neurological Sciences, 137: 20-27.

[73] Griffin, J.L., Williams, H.J., Sang, E., Nicholson, J.K. (2001). "Abnormal lipid profile of dystrophic cardiac tissue as demonstrated by one- and two-dimensional magic-angle spin- 
ning ${ }^{1} \mathrm{H}$ NMR spectroscopy."Magnetic Resonance in Medicine, 46: 249-255.

[74] Rae, C., Scott, R.B., Thompson, C.H., Dixon, R.M., Dumughn, I., Kemp, G.J., Male, A., Pike, M., Styles, P., Radda, G.K. (1998). "Brain biochemistry in Duchenne muscular dystrophy: a ${ }^{1} \mathrm{H}$ magnetic resonance and neuropsychological study."Journal of the Neurological Sciences, 160: 148-157.

[75] Griffin, J.L. (2004). "Metabolic Profiles to define the genome: can we hear the phenotypes?"Philosophical Transactions of the Royal Society of London, Series B, Biological Sciences, 359: 857-871.

[76] Griffin, J.L., Sang, E., Evens, T., Davies, K., Clarke, K. (2002). "Metabolic profiles of dystrophin and utrophin expression in mouse models of Duchenne muscular dystrophy."FEBS Letters, 530: 109-116.

[77] Huxtable, R.J. (1992). "Physiological actions of taurine."Physiolical Reviews, 72: 101-163.

[78] Tracey, I., Dunn, J. F., Parkes, H. G., Radda, G. K. (1996). "An in vivo and in vitro $\mathrm{H}$-magnetic resonance spectroscopy study of $\boldsymbol{m d x}$ mouse brain: Abnormal development or neural necrosis?"Journal of the Neurological Sciences, 141: 13-18.

[79] Cole, M.A., Rafael, J.A., Taylor, D.J., Lodi, R., Davies, K.E., Styles, P. (2002). "A quantitative study of bioenergetics in skeletal muscle lacking utrophin and dystrophin."Neuromuscular Disorders, 12: 247-257.

[80] Misra, L.K., Kasturi, S.R., Kundu, S.K., Harati, Y., Hazlewood, C.F., Luthra, M.G., Yamanashi, W.S., Munjaal, R.P., Amtey, S.R. (1982). "Evaluation of muscle degeneration in inherited muscular dystrophy by nuclear magnetic resonance techniques."Magnetic Resonance Imaging, 1: 75-79.

[81] Giesel, F.L., Stroick, M., Griebe, M., Tröster, H., von der Lieth, C.W., Requardt, M., Rius, M., Essig, M., Kauczor, H.U., Hennerici, M.G., Fatar, M. (2006). "Gadofluorine m uptake in stem cells as a new magnetic resonance imaging tracking method: an in vitro and in vivo study."Investigative Radiology, 41: 868-873. 
[82] Cahill, K.S., Gaidosh, G., Huard, J., Silver, X., Byrne, B.J., Walter, G.A. (2004). "Noninvasive monitoring and tracking of muscle stem cell transplants."'Transplantation, 78(11): 16261633.

[83] Genove, G., DeMarco, U., Xu, H., Goins, W.F., Ahrens, E.T. (2005). "A new transgene reporter for in vivo magnetic resonance imaging."Nature Medicine, 11(4): 450-04.

[84] Kaupinen, J. "Fourier Transforms in Spectroscopy"

[85] http://metabolibrary.ca/

[86] Guirard, B.M., Snell, E.E. (1987). "Purification and properties of pyridoxal-5'-phosphate-dependent histidine decarboxylases from Klebsiella planticola and Enterobacter aerogenes."Journal of Bacteriology, 169(9): 3963-3968.

[87] Camerino, D.C., Tricarico, D., Pierno, S., Desaphy, J.F., Liantonio, A., Pusch, M., Burdi, R., Camerino, C., Fraysse, B., De Luca, A. (2004). "Taurine and skeletal muscle disorders."Neurochemichal Research, 29(1): 135-142.

[88] McClure, W., Rabon, R.E., Ogawa, H., Tseng, B.S. (2007). "Upregulatios of the creatine synthetic pathway in skeletal muscles of mature $m d x$ mice."Neuromuscular Disorders, 17: 639-650.

[89] Louis, M., Raymackers, J.M., Debaix, H., Lebacq, J., Francaux, M. (2004). "Effect of creatine supplementation on skeletal muscle of $m d x$ mice."Muscle Nerve, 29: 687-692.

[90] Jolliffe, I., T. (2002) "Principal Component Analysis."2nd ed., Springer. 